A Research Report for Westinghouse Hanford Company

\title{
Single-Shell Tank Constituent Rankings for Use in Preparing Waste Characterization Plans
}

J. G. Droppo, Jr.

J. W. Buck

J. S. Wilbur

D. L. Strenge

M. D. Freshley

June 1991

Prepared for the U.S. Department of Energy under Contract DE-AC06-76RLO 1830

Pacific Northwest Laboratory

Operated for the U.S. Department of Energy by Battelle Memorial Institute 


\title{
DISCLAIMER
}

This report was prepared as an account of work sponsored by an agency of the United States Government. Neither the United States Government nor any agency thereof, nor Battelle Memorial Institute, nor any of their employees, makes any warranty, expressed or implied, or assumes any legal liability or responsibility for the accuracy, completeness, or usefulness of any information, apparatus, product, or process disclosed, or represents that its use would not infringe privately owned rights. Reference herein to any specific commercial product, process, or service by trade name, trademark, manufacturer, or otherwise does not necessarily constitute or imply its endorsement, recommendation, or favoring by the United States Government or any agency thereof, or Battelle Memorial Institute. The views and opinions of authors expressed herein do not necessarily state or reflect those of the United States Government or any agency thereof.

\author{
PACIFIC NORTHWEST LABORATORY \\ operated by \\ BATTELLE MEMORIAL INSTITUTE \\ for the \\ UNITED STATES DEPARTMENT OF ENERGY \\ under Contract DE-ACO6-76RLO 1830
}

Printed in the United States of America

Available to DOE and DOE contractors from the

Office of Scientific and Technical Information, P.O. Box 62, Oak Ridge, TN 37831; prices available from (615) 576-8401. FTS 626-8401.

Available to the public from the National Technical Information Service, U.S. Department of Commerce, 5285 Port Royal Rd., Springfield, VA 22161. 
PNL -7572

UC $-702,721$

A Research Report for Westinghouse Hanford Company

SINGLE-SHELL TANK CONSTITUENT RANKINGS FOR

USE IN PREPARING WASTE CHARACTERIZATION PLANS

J. G. Droppo, Jr.

J. W. Buck

J. S. Wi lbur

D. L. Strenge

M. D. Freshley

June 1991

Prepared for

the U.S. Department of Energy

under Contract DE-ACO6-76RLO 1830

Pacific Northwest Laboratory

Richland, Washington 99352 
. 


\section{PREFACE}

This effort is part of the initial exploratory characterization efforts for mixed wastes in underground single-shell tanks (SSTS) at the U.S. Department of Energy's (DOE) Hanford Site being conducted in accordance with DOE's waste characterization plan (Winters et al. 1989). The purpose of this analysis was to provide a preliminary ranking of the constituents in the SST waste and provide information for use in establishing detection limits for the analytical characterization of the wastes.

This report documents past efforts for use in ongoing SST characterization efforts. The bulk of the efforts described were conducted from April 1988 to September 1989. Since then, only minor corrections and updates have been made. Although the results from these efforts have been one source of information in the ongoing process of defining contaminants, the lists and their rationale are no longer current. The early nature of these efforts is evident in the use of tank groupings other than operable units that have been subsequently defined by the Federal Facilities Agreement and Consent Order (Tri-Party Agreement). This report provides a starting point for a planned update of the efforts described in this report. 



\section{ABSTRACT}

Waste characterization efforts for underground single-shell tanks (SSTs) containing chemical and radioactive mixed wastes at the U.S. Department of Energy's (DOE) Hanford Site are currently under way. As a component of this effort, an analysis was conducted to give a preliminary ranking of possible constituents in the SST waste and provide data for establishing detection limit requirements for the SST characterization effort. These SST constituent rankings were based on a relative comparison using potential human health impacts modeled using a hypothetical exposure scenario. This modeling effort used preliminary estimates of the SST inventories, simplified estimates of constituent release rates and environmental transport, a hypothetical usage location, and a standard Hanford exposure scenario.

The results of this evaluation are SST constituents for each of six groups of SSTs ranked according to their relative potential for impacts. The relative rankings for different recharge rates at the tank farms were nearly equivalent. Sensitivity tests demonstrated that the rankings are influenced by changes in recharge and transport parameters. 


\section{SUMMARY}

An initial evaluation was conducted of the relative importance of constituents stored in underground single-shell tanks (SSTs) at the U.S. Department of Energy's (DOE) Hanford Site. Single-shell tanks contain chemical and radioactive mixed waste from past Hanford operations.

This health impact-based ranking is one of the inputs in the SST waste characterization effort. In addition to this ranking, separate efforts will provide additional criteria to support the need to characterize levels of specific constituents in the SST tank wastes.

The evaluation of SST constituents described in this report was based on hypothetical predictions of potential human health impacts occurring as the result of groundwater contamination. These predictions, which provided a means of ranking the relative importance of the constituents, were generated using a preliminary characterization of possible SST constituents, simplified estimates of constituent release rates and environmental transport, a hypothetical usage location, and a standard Hanford exposure scenario.

$\lambda$ list of possible SST constituents includes those of concern in terms of potential health and regulatory considerations. A base list of constituents predicted by the Tracks Radioactive Constituents (TRAC) computer simulation of SST inventories was supplemented with additional constituents of regulatory concern that might, or are suspected to be, in the SSTs.

For constituents for which the inventory estimates were available and non-trivial (i.e., greater than zero), the tank-specific predictions by the TRAC computer program were used. For nonradioactive constituents not listed by TRAC that might exist in the SSTs, the rankings are based on the assumption that the mass of the constituent comprises a small, but nontrivial fraction of the wastes: an arbitrary inventory of $1 \%$ by weight was used.

At the Hanford site, the SSTs are located close to each other, and groups of tanks are denoted as "tank farms." Based on similarities in geologic settings, the inventories at the 12 SST farms were combined and considered as six tank farm groups. Following the nomenclature at Hanford 
for tank farms, these six are referred to as tank farm groups $A, B, C, S, T$, and $U$.

The constituent environmental movement was modeled using the Multimedia Environmental Pollutant Assessment System (MEPAS). The wastes from the SSTs assumed to be released into the unsaturated zone; the migration of these wastes was simulated through the unsaturated and saturated zones to a hypothetical usage location represented by a well $50 \mathrm{~m}$ downgradient from each tank farm. This transport scenario accounted for the geologic conditions associated with each tank farm group. A standard Hanford exposure scenario based on farm-related usage of the well water was used to evaluate potential impacts of SST constituents. These impacts at a hypothetical usage location for each tank farm group were computed out to 10,000 years in the future.

Studies were conducted for the tank farm groups with a range of recharge rates that have been considered for other Hanford applications $(0.5,1.0$, and $10.0 \mathrm{~cm} / \mathrm{yr}$ ). The relative rankings for different recharge rates at the tank farms were nearly equivalent. However, the faster environmental transport times associated with increasing recharge rates did increase the magnitude of the health impact indexes and resulted in the appearance of several new constituents in the ranking. As a result, a $10.0-\mathrm{cm} / \mathrm{yr}$ recharge rate was selected as the basis for the rankings.

In addition to the range of recharge rates, a transport sensitivity study considered the relationship between uncertainties in the distribution coefficients ( $K_{d} s$ ) and rankings. In this effort, a set of enhanced transport runs was made for tank farm group $A$ using the $10.0-\mathrm{cm} / \mathrm{yr}$ recharge and reduced $K_{d} s$ for each constituent with a non-zero $K_{d}$ value.

The sensitivity studies demonstrated that the rankings are influenced by changes in recharge rates and transport rates. The primary effect is mainly to add new constituents that are predicted to impact at a time near the end of the computational time period $(10,000$ years $)$.

The results show rankings with many orders of magnitude separation in relative importance of constituents from the perspective of relative health impacts. A large fraction of the constituents were predicted not to reach the well and thus were ranked as having no or very low potential for human 
health impact at this hypothetical receptor point. The rest of the constituents were ranked using the computed health impact indexes.

Although the results were similar for the different tank farm groups, there were some relatively large shifts in absolute as well as relative rankings between tank farm groups. These shifts are the direct result of differences in inventories and local geologic settings.

The highest ranking radionuclides (i.e., those with the largest predicted level of impact) in the tank farm groups were carbon-14, technetium-99, uranium-238, uranium-235, and iodine-129. Uranium-234, uranium-233, thorium-229, and niobium-93M generally had lower levels of predicted impacts and thus lower rankings. An increase in the relative importance of neptunium-237, protactinium-231, protactinium-233, and selenium- 79 was noted in the transport sensitivity test cases using enhanced transport rates.

For noncarcinogenic chemicals whose SST inventories were predicted by TRAC, cyanide ion, nitrite, nitrate, EDTA, fluoride, sodium, chromium VI, and sulfate tended to have the highest rankings. Beryllium ranked relatively high in all tank farms except $A$ and S. Zirconium, nicke1, and iron ranked high for Tank Farms $S, T$, and U. Silver and chloride ranked in the lower portion of the scale. The sensitivity study at Tank Farm A using enhanced transport rates resulted in the addition of zirconium to the rankings, a shift of iron from a low ranking to a high ranking, and some minor shifting of the ranking order of other constituents.

For noncarcinogenic chemicals without TRAC inventories, antimony, mercury, and vanadium consistently appeared in the rankings. Also ranking in this category of chemicals are sulfate (Tank Farm S), cadmium (Tank Farms $T$ and $U$ ), and copper (Tank Farm U). The transport sensitivity study using enhanced transport resulted in additional appearances of copper and selenium in the rankings. For carcinogenic chemicals modeled with an assumed inventory, only arsenic appeared in any of the ranking results.

The use of preliminary inventory estimates for the possible SST constituent inventories represents a major source of uncertainty in the rankings. In addition, the use of simplified release, transport, and 
exposure predictions limits the use of the results to relative comparisons of potential health impacts. The overall ranking results cover a sufficiently wide range in impacts; however, orders of magnitude change can occur in a computed impact without significantly changing these overall rankings. 


\section{CONTENTS}

PREFACE ............................

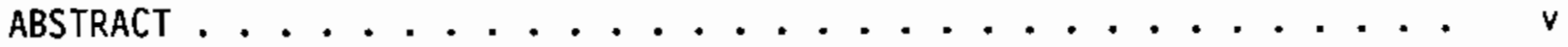

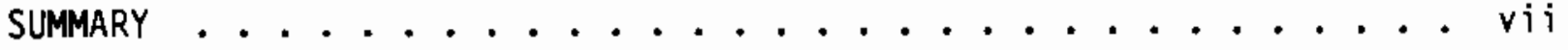

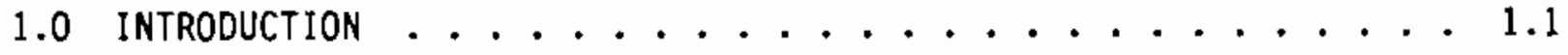

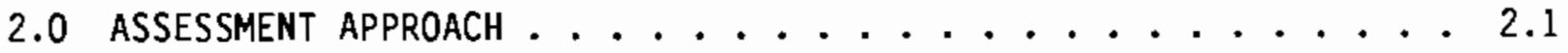

3.0 SINGLE-SHELL TANK CONSTITUENTS $\ldots \ldots \ldots . \ldots \ldots$

SINGLE-SHELL TANK INVENTORIES ............ 3.2

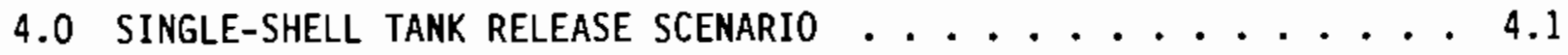

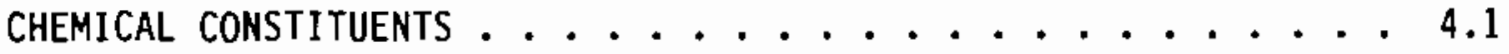

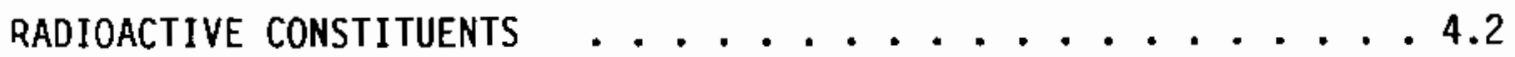

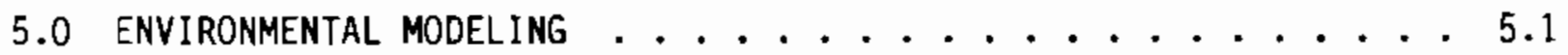
GEOLOGY BENEATH THE SINGLE-SHELL TANK FARM GROUPS . . . . . 5.1 TRANSPORT PARAMETERS ................ 5.3

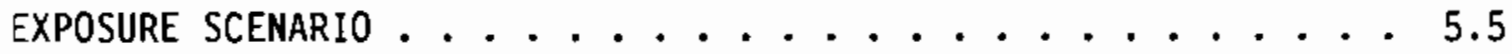
HEALTH IMPACT RANKING INDICES ............. 5.6

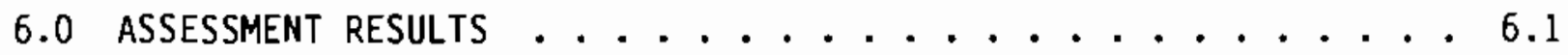

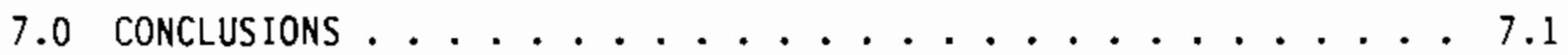

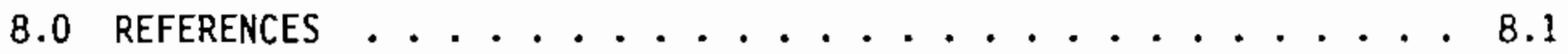
APPENDIX A - TRAC RADIONUCLIDE INVENTORY FOR SINGLE-SHELL TANK FARMS - A.1 APPENDIX B - TRAC CHEMICAL SINGLE-SHELL TANK FARM INVENTORIES . . B. B APPENDIX C - PHYSICAL PARAMETERS FOR CHEMICAL CONSTITUENTS . . . . C. .1 APPENDIX D - RADIONUCLIOE FLUX RATES AND RELEASE DURATION . . . . D.1 APPENDIX E - SINGLE-SHELL TANK HYDROLOGIC PARAMETERS ........ E.1 
APPENDIX $F$ - PHYSICAL PARAMETERS FOR RADIONUCLIOES . . . . . . F.1 APPENDIX G - PEAK CONCENTRATIONS COMPUTEO IN HYPOTHETICAL WELLS . . . G.1 APPENDIX H - TABLES OF HEALTH RANKING INDICES .......... H.1 


\section{FIGURES}

6.1 Radioactive and Carcinogenic Chemicals Rankings for

Tank Farm Group A with a Recharge Rate of $0.5 \mathrm{~cm} / \mathrm{yr}$. . . . . . . 6.3

6.2 Radioactive and Carcinogenic Chemicals Rankings for

Tank Farm Group A with a Recharge Rate of $1.0 \mathrm{~cm} / \mathrm{yr}$. .. . . . 6.4

6.3 Radioactive and Carcinogenic Chemicals Rankings for

Tank Farm Group A with a Recharge Rate of $10.0 \mathrm{~cm} / \mathrm{yr} \ldots . . .66 .5$

$6.4 K_{d}$ Sensitivity Test Rankings for Radioactive and

Carcinogenic Chemicals in Tank Farm Group A with a Recharge Rate

of $10.0 \mathrm{~cm} / \mathrm{yr} \ldots \ldots \ldots . \ldots . \ldots . . \ldots 6$

6.5 Radioactive and Carcinogenic Chemicals Rankings for

Tank Farm Group B with a Recharge Rate of $10.0 \mathrm{~cm} / \mathrm{yr}$. . . . . 6.7

6.6 Radioactive and Carcinogenic Chemicals Rankings for

Tank Farm Group C with a Recharge Rate of $10.0 \mathrm{~cm} / \mathrm{yr}$. . . . . 6.8

6.7 Radioactive and Carcinogenic Chemicals Rankings for

Tank Farm Group $S$ with a Recharge Rate of $10.0 \mathrm{~cm} / \mathrm{yr}$. . . . . 6.9

6.8 Radioactive and Carcinogenic Chemicals Rankings for

Tank Farm Group T with a Recharge Rate of $10.0 \mathrm{~cm} / \mathrm{yr}$. . . . . 6.10

6.9 Radioactive and Carcinogenic Chemicals Rankings for

Tank Farm Group U with a Recharge Rate of $10.0 \mathrm{~cm} / \mathrm{yr}$. . . . . 6.11

6.10 Noncarcinogenic Chemicals Rankings for Tank Farm Group A with a

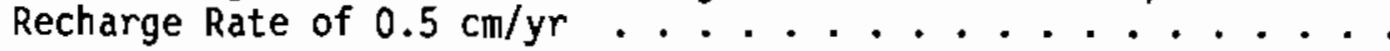

6.11 Noncarcinogenic Chemicals Rankings for Tank Farm Group A with a Recharge Rate of $1.0 \mathrm{~cm} / \mathrm{yr} \ldots \ldots . . . \ldots$

6.12 Noncarcinogenic Chemicals Rankings for Tank Farm Group A with a Recharge Rate of $10.0 \mathrm{~cm} / \mathrm{yr} \ldots \ldots . . . \ldots$

$6.13 \mathrm{Kd}_{\mathrm{d}}$ Sensitivity Test Rankings for Noncarcinogenic Chemicals in Tank Farm Group A with a Recharge Rate of $10.0 \mathrm{~cm} / \mathrm{yr}$. . . . 6.15

6.14 Noncarcinogenic Chemicals Rankings for Tank Farm Group B with a Recharge Rate of $10.0 \mathrm{~cm} / \mathrm{yr}$............. 6.16

6.15 Noncarcinogenic Chemicals Rankings for Tank Farm Group $\mathrm{C}$ with a Recharge Rate of $10.0 \mathrm{~cm} / \mathrm{yr}$............. 6.17

6.16 Noncarcinogenic Chemicals Rankings for Tank Farm Group $S$ with a Recharge Rate of $10.0 \mathrm{~cm} / \mathrm{yr}$ 
6.17 Noncarcinogenic Chemicals Rankings for Tank Farm Group T with a Recharge Rate of $10.0 \mathrm{~cm} / \mathrm{yr}$........... . 6.19

6.18 Noncarcinogenic Chemicals Rankings for Tank Farm Group U with a Recharge Rate of $10.0 \mathrm{~cm} / \mathrm{yr} \ldots \ldots . . . . . . .66$ 


\section{$\underline{\text { TABLES }}$}

5.1 Representative Soil Characteristics . . . . . . . . . . 5.4

5.2 Decay Products Potentially Moving Faster Than Parent Material . . . 5.8 


\subsection{INTRODUCTION}

Pacific Northwest Laboratory (PNL) (a) conducted an health-based evaluation of the relative importance of constituents that may be contained in underground single-shell tanks (SSTs) located on the Hanford Site. single-shell tanks are used for the storage of chemical and radioactive mixed waste generated during past Hanford operations (DOE 1987). This effort is part of a larger effort aimed at characterizing the wastes in the SSTs.

The objective of this study was to provide relative rankings of the constituents that potentially need to be characterized in Hanford SSTs. These relative rankings of constituents were based on public-health impacts computed for usage at a hypothetical location. Because of the early stage of this effort, this study was based on possible constituents in SSTs. As a result some of the constituents considered in this study may not be found in the SST wastes. These rankings are one of the initial inputs to an ongoing SST waste characterization effort which has a long-range objective to provide recommendations for SST waste retrieval and disposal decisions.

These SSTs were designed as intermediate underground storage facilities for high-level radioactive wastes produced by nuclear fuel separation processes which occurred in the 200 East and 200 West Areas of the Hanford Site (DOE 1987). A total of 149 SSTs are located in the 200 East and 200 West Areas of the Hanford Site; 66 underground SSTs are located in the 200 East Area, and 83 underground SSTs are located in the 200 West Area. The capacity of the SSTs ranges from 210 to $3800 \mathrm{~m}^{3}$. Replacement of these single-wall storage tanks with double-wall or double-shell tanks began in 1970 (DOE 1987).

The tanks are located close to each other in "tank farms" near fuel separation facilities. There is a total of 12 individual SST farms, each of which is assigned a label ( $S, S X, T, T X, T Y, U, A, A X, B, B X, B Y$, and $C$ ). The six labels for the SST farms (S, T, U, A, B, and C) correspond to one of the five specific reactor fuel separation processes ( $S, T, U, A$, and $B$ ) that were used at Hanford (DOE 1987). The C processing facility was never

(a) Operated for the U.S. Department of Energy by Battelle Memorial Institute. 
constructed, but the $\mathrm{C}$ tank farm label was assigned to a single tank farm. In the early years (1945-1955), each SST farm at the Hanford Site received and stored wastes for a given fuel separation process (DOE 1987).

As of the time this effort was conducted, only a few samples from SSTs were collected and analyzed for certain constituents. Attempts to collect and analyze samples from individual SSTs have been difficult because of the variability of each SST waste form and sampling logistics required to minimize occupation exposures to radioactivity in the tanks. Results of this sampling effort, along with a discussion of problems in the recovery of adequate core samples from the tanks for analysis, are included in Weiss (1986) and Schulz (1978). Although based on an analysis of actual tank samples, these data were not used to define tank inventories in this report because no information was available on how representative these data were for the SSTs or even for the tank which was sampled.

The inventories used in this report are from a computer simulation of radioactive and some nonradioactive constituents present in SSTs with the Tracks Radioactive Components (TRAC) computer code developed by the West inghouse Hanford Company (Morgan et al. 1988). The TRAC code computes current inventories based on quantities of materials (radioactive and chemical) initially placed into tanks from nuclear fuels production, reprocessing and waste management, tank transfers, and radioactive decay. These TRAC inventory estimates, although recognized as having serious limitations, represent the best current information on the content of SSTs.

This study is one of several past and ongoing efforts considering potential impacts of waste materials stored on the Hanford Site. The Hanford Defense waste Environmental Impact Statement (EIS) (DOE 1987) provides an overview of potential impacts from a wide range of activities. The Hanford Grout Performance Assessment studies are more detailed modeling efforts that provide guidance for engineering waste containment options (Sewart et al. 1987). The study reported here is a preliminary screening to provide input to the plan for characterizing radioactive and chemical wastes in the Hanford SSTs (winters et al. 1989). 
Previous assessments of Hanford wastes that considered similar settings provided a starting point for this effort. Although this study was conducted in a manner consistent with these past efforts, differences in the modeling assumptions occur as the result of different study objectives, different waste forms, and use of more recent information.

The modeling conducted for public health-based evaluation of the relative importance of SST wastes uses an estimate of the possible constituents in the SSTs, simulates the release and movement of these constituents in the groundwater to a hypothetical nearby usage location, and then computes potential human exposures. The rankings of constituents are based on the health impacts implied by these exposures.

The modeling approach for this study is described in Section 2.0. Detailed information on SST constituents that were considered and their release and movement in the environment are given in Sections 3.0, 4.0, and 5.0. Finally, the results are presented in Section 6.0. 



\subsection{ASSESSMENT APPROACH}

This assessment is based on estimates of potential public health impacts from water usage at a hypothetical location. Initial estimates of the SST inventories, constituent release rates, environmental transport, and exposure scenarios were used as input to the Multimedia Environmental Pollutant Assessment System (MEPAS) (Whelan et al. 1987; Droppo et al. 1989). For this assessment, the list of possible SST constituents includes those of potential health and regulatory concerns. A base list of constituents predicted with a TRAC computer simulation of SSTs inventories was supplemented with additional constituents of regulatory concern that may (or are suspected to) be present in the SST wastes. Thus the constituents in the SST wastes evaluated in this study include those that are known to exist, some that are suspected to exist, and some whose presence or absence needs to be defined from a regulatory standpoint. The characterization of SST wastes will be an iterative process. As characterization proceeds, future assessments will be more refined.

Based on information from past studies at the Hanford Site, it was determined that there are six geologic settings associated with the 12 SST farms. These six geologic settings represent different geologic and hydrologic conditions present beneath the SST farms. (a) The 12 SST farms at Hanford were combined and considered as six tank farm groups designated as Tank Farm Groups A ( $A$ and AX SST farms), B (B, BX, and BY SST farms), C (C SST farm), S ( $S$ and SX SST farms), $T$ ( $T, T X$, and TY SST farms), and $U$ (U SST farm). The inventories and geologic settings for each of these tank farm groups are described in Sections 2.0 and 5.0, respectively.

The release of the inventories for each tank farm group is based on a simplified waste form. All wastes from each tank farm group are assumed to be aggregated in a large underground tank with completely permeable walls. Wastes are then released to the environment though solubility controlled releases as described in Section 4.0 .

(a) These groupings differ from the operable units subsequently defined by the Tri-Party Agreement. 
The transport of SST wastes in Hanford soils and groundwater was simulated with the groundwater component of MEPAS. Transport was predicted through the unsaturated and saturated zones to a hypothetical usage location represented by a we $1150 \mathrm{~m}$ downgradient from each tank farm. Because the potential receptor population in the Hanford region actually occurs considerably farther downgradient, this approach is merely a convenient method of computing impacts with minimum dispersion for comparative purposes. Potential human health impacts were computed at the hypothetical usage location for each tank farm group out to 10,000 years in the future.

A standard Hanford "farm exposure scenario" involving direct human and agricultural usage of well water was selected as a scenario that included all major exposure routes. This farm exposure scenario provides a means of computing potential health impacts for comparative purposes based on Hanfordarea information. This exposure scenario was patterned after a similar scenario used in the Hanford Grout Performance Assessment (Sewart et al. 1987). The only major difference in approach was a result of different study objectives, a hypothetical well location was selected that was closer than the 5-km downgradient location. 


\subsection{SINGLE-SHELL TANK CONSTITUENTS}

The Hanford Defense Waste EIS (DOE 1987) describes the SST waste forms and their origins. Single-shell tank wastes occur in both solid and liquid forms and contain both radioactive and nonradioactive constituents. The solid forms are called salt cake and sludge, and the liquid fractions are known as supernatant and interstitial liquors. Most of the SST wastes received additional processing for the removal of the $90 \mathrm{Sr}$ and $137 \mathrm{Cs}$ isotopes, which were the major contributors of heat in SST wastes. This additional processing effort involved pumping liquid wastes from the SSTs. The pumped SST wastes were transported via pipelines to the 200 East Area B Plant, where the $90 \mathrm{Sr}$ and $137 \mathrm{Cs}$ isotopes were removed. The remaining, or residual, SST wastes were then returned to the SST farms, but not necessarily to the original tank or tank farm. The transfers between tanks during these operations make the definition of the current content of each tank or tank farm a difficult task.

The TRAC computer code was designed to estimate inventories of radionuclides. This analysis started with a list of 68 radionuclides in the TRAC outputs provided by Westinghouse Hanford Company. Radionuclides with zero inventories or short half-lives (i.e., less than 1 year) were eliminated.(a) The decision was made not to further reduce the list of radionuclides. The resulting list of 40 radionuclides was considered in this analysis using the TRAC inventory estimates.

Winters et al. (1989) developed a separate list of 42 radionuclides based on regulatory concerns for disposal decisions. Their list excluded some of the radionuclides modeled in this effort and included some radionuclides not in the TRAC output. Only radionuclides with TRAC inventory estimates were considered in the effort reported here.

The analysis for nonradioactive materials started with a list (Winters et al. 1989) generally based on regulatory concern (Keller et al. 1989). Materials that are not expected to exist in the SST environment (eievated

(a) $126 \mathrm{Sn}$ and $93 \mathrm{Zr}$ were inadvertently eliminated and will need to be considered in future efforts. 
temperatures, high $\mathrm{pH}$, and high levels of radiation) were not considered. For example, organics and acids are not expected in their original form, and were not modeled.(a) The TRAC computer code was not designed to estimate inventories of nonradioactive chemicals, but does provide inventory estimates for a few chemicals as part of the tracking of radionuclides. These TRAC inventory estimates were used as available. Arbitrary inventories of $1 \%$ by weight of the SST was assumed for nonradioactive materials without an estimated inventory.

\section{SINGLE-SHELL TANK INVENTORIES}

The computer-generated inventories of radioactive and chemical constituents in the SST wastes used for this study were prepared in 1988 by Westinghouse Hanford Company with the TRAC computer code (Adams, Jensen, and Schulz 1986). The TRAC computations generated inventories of 68 radionuclides and 30 chemical constituents. Of the 68 radioactive constituents in the SST wastes reported by TRAC, 40 were considered in this assessment. TRAC inventory data were reported for individual tanks for the radionuclide and chemical constituents. The constituent inventories for the tank farm groups were obtained by sumning these radioactive and chemical inventories within each tank farm group.

The inventories reported by TRAC for individual radionuclides were in units of curies per thousand gallons ( $\mathrm{Ci} / \mathrm{Kgal})$ of SST wastes. These inventories were projected to January 1, 1990, to account for radioactive decay. In this study, radionuclide inventories were converted from units of curies per thousand gallons to units of curies per gram of waste for input to the MEPAS code. The converted TRAC radionuclide inventories are listed by tank farm group in Appendix A. The density for the total SST waste inventory used in the TRAC analysis supplied by Westinghouse Hanford Company is $1.8 \mathrm{~g} / \mathrm{cm}^{3}$.

The chemical inventory estimates are listed by tank farm group in Appendix B. The TRAC chemicals that were not simulated and the reasons for

(a) Organics and acids as well as $\mathrm{Bi}, \mathrm{NH}_{4}{ }^{+}$, and $\mathrm{5}-2$ were not modeled in this effort and will need to be addressed in future efforts. 
not including them are also documented in Appendix $B$. The nonradioactive chemical inventories predicted with TRAC were presented in units of moles per thousand gallons $(\mathrm{M} / \mathrm{Kgal})$. The chemical constituents were converted from the units of moles per thousand gallons reported by the TRAC code to units of grams per gram of waste for input to the MEPAS code.

Some nonradioactive chemicals considered from Winters (1989) were not in the TRAC outputs and therefore did not have inventory estimates. These chemicals are $\mathrm{As}, \mathrm{Be}, \mathrm{Cd}, \mathrm{Cu}, \mathrm{Hg}, \mathrm{Sb}, \mathrm{Se}$, and $\mathrm{V}$. To predict impacts for these constituents, the inventory for each such constituent was set to an arbitrary fraction of the waste; specifically an inventory was assumed of $1 \%$ by weight of the SST waste for each tank farm group. 



\subsection{SINGLE-SHELL TANK RELEASE SCENARIO}

A11 constituents released from the SST wastes were assumed to be in the solid form and were simulated as leached from the waste form with no container (tank) present. The potential releases of radioactive and chemical constituents from SST wastes at each tank farm group were modeled as though the wastes were contained in a single tank with an expanded radius. The equivalent area for this single tank was computed as the sum of tank areas within each tank farm group. Volumetric flow rates for each of the tank farm groups were determined by multiplying the equivalent area by the annual amount of water assumed to pass through the tank farm group area resulting from natural recharge. The depth to groundwater beneath each of the tank farm groups was based on the Hanford Site water table measurement data reported by Schatz and McElroy (1988).

Single-shell tank waste releases were computed for recharge rates of $0.5,1.0$, and $10.0 \mathrm{~cm} / \mathrm{yr}$ to bound the range of rates described in Gee (1987). A recharge rate of $10.0 \mathrm{~cm} / \mathrm{yr}$, which results in the fastest release of SST constituents, roughly corresponds to a tank farm group with a gravel surface cover. Recharge rates of 0.5 and $1.0 \mathrm{~cm} / \mathrm{yr}$, which produce slower constituent release rates, represent conditions where vegetation is present above the tank farm group. Small amounts of recharge would be expected with placement of barriers above the tanks.

The release of constituents from the SST waste inventories was simulated with solubility limits for chemical constituents and a modified solubility method for radioactive constituents.

\section{CHEMICAL CONSTITUENTS}

Solubility limits for chemical constituents were obtained from Weiss (1986). Weiss agitated several samples of SST wastes in a water bath and analyzed the water from these tests to determine the solubility of the constituents. Average solubility values for chemical constituents were computed from the data reported by Weiss. Solubility values for chemicals not included in the Weiss study were obtained from a chemical handbook (CRC 1988). Since the completion of this effort, Serne and Wood (1990) have provided a sumary of solubilities for Hanford which supersede the estimates 
used here. In future assessments for SST waste characterization work, their revised solubility values, perhaps supplemented with additional measured values from water leachate tests, will be used.

Appendix $C$ lists the solubility limits, half-lives and $K_{d}$ values used by this study for the chemical constituents.

\section{RADIOACTIVE CONSTITUENTS}

Solubilities for radionuclides were reported in Weiss (1986) as gross alpha, beta, and gamma activity and not by individual radionuclides. Therefore, the reported solubilities were not useful in this assessment of individual radionuclides.

For radioactive constituents in the SST wastes, a congruent release method was used to estimate release rates. The congruent release method is a relatively standard approach used when detailed information is not available on the solubility of many of the constituents. The method, as implemented in this study, will provide a conservative (i.e., high) release rate for most of the constituents.

In the congruent release method, the release of a major, relatively soluble fraction (sodium nitrate) of the SST wastes is assumed to control the release of all constituents. All the radionuclides are assumed to be homogeneously mixed in the solid sodium nitrate phase of the SST wastes. The TRAC inventories for sodium and nitrate were used to calculate a maximum sodium nitrate inventory for each of the SST farms modeled. Based on this inventory of sodium nitrate, the time period for the total release of sodium nitrate was computed. The release of each of the radioactive constituents was assumed to occur over the same period as the sodium nitrate. A sodium nitrate solubility of $921 \mathrm{~g} / \mathrm{L}$ water (CRC 1988) was used to compute the release rate. This solubility rate for the congruent release was selected to provide conservative estimates of release time rather than the lower value previously used at hanford (DOE 1987). This release computation was made for the three annual recharge rates $(0.5,1.0$, and $10.0 \mathrm{~cm} / \mathrm{yr})$. Appendix $D$ lists the number of years to release the radionuclides for each recharge rate for all tank farm groups based on the duration for all the materials to leach into the soil from the waste tank. 


\subsection{ENVIRONMENTAL MODELING}

This section covers the modeling of SST constituent movement and uptake at a hypothetical receptor location. This includes the geology and hydrology used in the environmental transport computations as well as assumptions for the computation for potential health impacts.

The single-shell tanks are located at the Hanford Site in an arid region of the Columbia Basin (Jaquish and Mitchell 1988). The main geologic units present beneath the Site are the Columbia River Basalt Group, the Ringold Formation, and a series of glaciofluvial sands and gravels informally named the Hanford formation. Groundwater is present in both confined and unconfined aquifers beneath the site. The unconfined aquifer has been impacted by Hanford Site operations more than the confined aquifers. In this assessment for SST wastes, the transport of wastes in groundwater is assumed to occur in the unconfined aquifer system. The uppermost aquifer beneath the SST farms is an unconfined aquifer contained within the sediments of the Hanford and Ringold formations overlying the basalts (Graham et al. 1981).

\section{GEOLOGY BENEATH THE SINGLE-SHELL TANK FARM GROUPS}

The six geologic settings modeled in this study correspond to geologic conditions beneath the $A, B, C, S, T$, and $U$ tank farm groups. The $S, T, A$, $B$, and $C$ tank farm groups consist of a minimum of one and a maximum of three individual tank farms. Each SST farm contains as few as 6 and as many as 18 tanks. The tops of the tanks are from 1.8 to $3.0 \mathrm{~m}$ below the surface. Tank bottoms are from 11.5 to $15.0 \mathrm{~m}$ below the ground surface and 42 to $70 \mathrm{~m}$ above the water table.

The SSTs are buried in soils derived from sediments. The Hanford and Ringold formations are of interest to this study because they comprise the unsaturated and saturated zones beneath the SST farms. The geologic cross sections and the hydrologic parameters of the unsaturated and saturated zones beneath the SST farms were based on sediment textural data.

Sediment cores collected during construction of groundwater monitoring wells at the SST farms were sieved to obtain percent grain size (textural) data. The textural data from these cores were used to define sediment types 
based on relative percentages of the sand, silt, and clay fractions present in each sample. Textural data were used to define the sediment types present and to determine the depths at which they occur in geologic cross sections. The textural data obtained for core samples collected at the Hanford Site are summarized and stored for retrieval in the ROCKSAN database described in Price and Fecht (1976a through d) and Fecht and Price (1977a through 1). Additional lithologic data for each of the SST farms were obtained from geologic cross-section reports on the individual SST farms by Price and Fecht (1976a through 1), Fecht and Price (1977a through 1), and Tallman et al. (1979). By combining these data sets, representative geologic cross sections for the unsaturated and saturated zones beneath each of the SST farms were determined.

The textural data were used to group lithologies in the cross sections into composite lithologies for each tank farm. The thickness of the sediments with equivalent textures at a tank farm were summed to create a single unit (layer) with fixed textural characteristics. This was done for each of the individual sediment types present at each of the SST farms. Care was taken in assigning the correct textural data to the depths where the unsaturated sediment layers are located beneath each of the SST farms. Although the unsaturated zone data used for the study are composites, they reflect the actual thicknesses of the various sediment types beneath an individual SST farm.

By constructing and comparing composite lithologies for the 12 tank farms, similarities in cross-section stratigraphies were noted among tank farms. Because of these similarities, the number of SST farms modeled by this study was reduced. Based on similar stratigraphies, the SST farms were clustered in the six tank farm groups described above.

For this study, the tank farms were divided into six subsets based on the general geology beneath them. These subsets were assigned to either the 200 East Area (A, B, and C Tank Farms) or 200 West Area (S, T, and $U$ tank farms). Sediments associated with each of these areas are distinct enough that significant differences are noted in the hydraulic parameters. In general, the sediments in and around the 200 West Area were deposited in a low-energy lake environment (Graham et al. 1981) while the sediments in and 
around the 200 East Area were deposited in a high-energy fluvial environment. The sediments in and around the 200 West Area are finer grained (silts and clays) compared to the coarser sediments (gravels and sands) deposited in and around the 200 East Area. Based on the differences in the textural percentages of the sediments, different sets of hydraulic parameters were used for the 200 East and 200 West Areas.

\section{TRANSPORT PARAMETERS}

The groundwater transport parameters required to simulate flow and transport through the unsaturated and saturated zones of this aquifer with the MEPAS code are described in the MEPAS application guideline document, Droppo et al. (1989, Volume 2). Table 5.1 is a reproduction of the Table 2.1 in Droppo et al. (1989) and is used extensively in this report for groundwater input parameters.

Hydrologic parameters for the textural units in the unsaturated and saturated zones are based on Table 5.1. For this study, the unsaturated zone lithologies consisted of a minimum of two and maximum of seven textural units. The hydrologic parameters assigned to the individual unsaturated and saturated zones for the SST farms are listed in Appendix E.

The depths to the water table for each of the tank farm groups were obtained from June 1988 Hanford groundwater measurement data (Schatz and MCElroy 1988).

The saturated zones beneath all the tank farm groups were assigned hydraulic parameter values for sand-sized materials based on parameter data as listed in Table 5.1. This table was used to determine all hydraulic transport parameters except the groundwater flow velocity. Groundwater flow velocities of 0.3 and $1.5 \mathrm{~m} /$ day were used for the SST farms in the 200 West and 200 East Areas, respectively, based on Graham et al. (1981).

A constant thickness of $4.57 \mathrm{~m}$ was used to model where the hypothetical well intercepts the saturated zone for all tank farm groups. This thickness represents a maximum limit of vertical mixing and was selected to be consistent with previous modeling efforts for the Hanford Grout Performance Assessment studies (Sewart et a1. 1987). Water concentrations are computed 
IABLE 5.1. Representative Soil Characteristics(a)

\begin{tabular}{|c|c|c|c|c|c|c|c|}
\hline $\begin{array}{c}\text { Soil-Texture } \\
\text { Classification }\end{array}$ & $\begin{array}{c}\text { Clas } \\
\text { Sand } \\
\frac{0}{6} \\
\end{array}$ & $\begin{array}{r}\text { Soil } \\
\text { sific } \\
\text { Silt } \\
\frac{8}{6} \\
\end{array}$ & ion & $\begin{array}{l}\text { Saturated } \\
\text { Hydraulic } \\
\text { Conductivity } \\
\text { (ft/day) } \\
\end{array}$ & $\begin{array}{c}\text { Porosity } \\
\left(\frac{(6)}{6}\right.\end{array}$ & $\begin{array}{c}\text { Bulk } \\
\text { Density } \\
\text { (g/cm) }\end{array}$ & $\begin{array}{c}\text { Field } \\
\text { Capacity } \\
(\%) \\
\end{array}$ \\
\hline Sand & 95 & 3 & 2 & $2.9 E+03$ & 38.0 & 1.64 & 9.0 \\
\hline Loamy sand & 84 & 12 & 4 & $3.2 E+02$ & 43.7 & 1.49 & 12.0 \\
\hline Sandy loam & 65 & 25 & 10 & $4.9 \mathrm{E}+01$ & 44.2 & 1.48 & 17.5 \\
\hline Loam & 45 & 40 & 15 & $1.5 E+01$ & 46.6 & 1.42 & 23.5 \\
\hline Silty loam & 25 & 63 & 12 & $5.6 E+00$ & 46.3 & 1.42 & 27.5 \\
\hline Silt & 8 & 87 & 5 & $2.9 \mathrm{E}+00$ & 44.2 & 1.48 & 28.0 \\
\hline Sandy clay loam & 60 & 14 & 26 & $1.6 \mathrm{E}+00$ & 39.8 & 1.60 & 24.0 \\
\hline Clay loam & 31 & 36 & 33 & $4.9 \mathrm{E}-01$ & 47.7 & 1.39 & 34.0 \\
\hline Silty clay loam & 10 & 58 & 32 & $3.3 \mathrm{E}-01$ & 49.0 & 1.35 & 37.5 \\
\hline Sandy clay & 50 & 8 & 42 & $1.7 \mathrm{E}-01$ & 43.0 & 1.51 & 32.0 \\
\hline Silty clay & 8 & 47 & 45 & $1.2 E-01$ & 48.6 & 1.36 & 42.0 \\
\hline Clay & 35 & 15 & 50 & 7.9E-02 & 47.5 & 1.39 & 40.0 \\
\hline
\end{tabular}

(a) These values are taken directly from MEPAS Application Guidance Document (Droppo et al. 1989).

at a hypothetical well located $50 \mathrm{~m}$ downgradient from the boundary of each of the SST farm groups.

The adsorption coefficient $\left(K_{d}\right)$ and half-lives of the radionuclides for this analysis are listed in Appendix $F$. The adsorption coefficient and solubility limits used for nonradioactive chemical constituents are listed in Appendix $C$. The $K_{d}$ values, for both radioactive and chemical constituents, are derived from whelan et a1. (1987), Droppo et al. (1989), and Strenge and Peterson (1989). 
In addition to considering a range of possible recharge rates, a sensitivity analysis was conducted for the adsorption coefficients ( $K_{d} s$ ). For Tank Farm Group A with a $10.0-\mathrm{cm} / \mathrm{yr}$ recharge, the $\mathrm{K}_{\mathrm{d}}$ values were reduced by a factor of 5 . This factor represents a rough estimate of the uncertainty in $K_{d}$ magnitudes selected as a midpoint of values from previous uncertainty studies.

\section{EXPOSURE SCENARIO}

The ranking of SST constituents was based on the exposure model described in whelan et al. (1987) with the exposure parameters documented in Strenge and Peterson (1989). The Hanford farm exposure scenario provides a means of computing relative health impacts from SST constituents based on major direct and indirect routes of exposure to people through common domestic and agricultural water usage.

In the farm exposure scenario, it is assumed that a family obtains all of their drinking water and one-fourth of their farm products from contaminated irrigation water from the hypothetical well. Farm products are considered contaminated when the well water is used to irrigate the food crops, irrigate animal feed crops, and water animals. The total intake of farm products by an individual of the family is assumed to be the following: leafy vegetables, $7.5 \mathrm{~kg} / \mathrm{yr}$; other vegetables, $160 \mathrm{~kg} / \mathrm{yr}$; meat, $24.5 \mathrm{~kg} / \mathrm{yr}$; and $m i l k, 69 \mathrm{~kg} / \mathrm{yr}$. The exposure scenario is evaluated for each constituent using the maximum water concentration for a 70-year lifetime over the modeling period $(10,000$ years $)$.

The computed human health impacts resulting from a hypothetical farm exposure scenario provide a measure of importance that includes components of a range of possible exposure routes. Because the location of the hypothetical wells immediately downgradient of the tank farm groups is very unlikely, the results are not considered realistic measures of absolute impacts. Rather, the predicted impacts at the well were used to provide a ranking of the constituents by relative importance. 


\section{HEALTH IMPACT RANKING INDICES}

The total health impact rankings from the farm exposure scenario for radioactive carcinogens, chemical carcinogens, and chemical noncarcinogens are reported in terms of a ranking index. The ranking index formulations for radioactive constituents $\left(R I_{R}\right)$, for carcinogenic constituents $(R I C)$, and for noncarcinogenic constituents (RIN) are presented below. (The dose computed for each constituent is based on the maximum water concentration for the modeling period.) The ranking indices are reported separately reflecting the different nature of impacts (i.e., carcinogens versus and noncarcinogens) and possible uncertainty in the equivalence of carcinogenic effects.

For radionuclides the ranking index is evaluated using an effective dose equivalent (EDE) for an individual exposed for a 70-year lifetime in a farming scenario. The health effects conversion factor $\left(H_{E}\right)$, expressed as risk per unit dose, was the value derived by Buhl and Hansen (1984) from NAS (1980).

$$
R I_{R}=(E D E) \times H_{E}
$$

where $R_{R}=$ ranking index for a radionuclide

$$
\begin{aligned}
E D E= & \text { maximum effective dose equivalent for lifetime exposure } \\
& \text { for an individual, rem } \\
H_{E}= & \text { health effect conversion factor, } 2.7 \times 10^{-4} \text { health } \\
& \text { effects per rem lifetime exposure }
\end{aligned}
$$

For carcinogenic chemicals, the ranking index is evaluated consistent with EPA's guidance for carcinogenic risk levels (EPA 1989) using a chemical specific cancer potency factor.

$$
R_{C}=D \times C P F
$$

where $R_{C} C=$ ranking index for a carcinogenic chemical

$$
\begin{aligned}
D= & \text { maximum lifetime intake rate of a chemical, } \\
& m g^{\star} d / \mathrm{kg}
\end{aligned}
$$


The ranking indices for radionuclides and carcinogenic chemicals are approximately comparable because both are based on estimates of latent cancer fatalities. The ranking index for noncarcinogenic chemicals, on the other hand, is not related to any specific fatal effect.

The noncarcinogen ranking index is evaluated following EPA's guidance for noncarcinogenic hazard quotients (EPA 1989):

$$
R I_{N}=D / R f D
$$

where $\mathrm{RI}_{\mathrm{N}}=$ ranking index for a noncarcinogenic chemical

$D=$ maximum lifetime intake rate of a chemical, $\mathrm{mg} / \mathrm{kg} / \mathrm{d}$

$R f D=$ reference dose for the chemical, $\mathrm{mg} / \mathrm{kg} / \mathrm{d}$

The reference dose is an intake level that represents a safe level of intake for continuous exposure over the lifetime of an individual.

Indices for both radioactive and chemical carcinogens are based on similar risk-based considerations. On these scales, a value of 10-6 is considered a typically acceptable level of protection.

The impacts of noncarcinogens are normally assumed to occur only at concentrations greater than some threshold value. The scale for the noncarcinogenic ranking index is such that a value equal to or less than 1.0 indicates the computed levels for the hypothetical exposure scenario are below those at which effects are expected.

In MEPAS, decay products are assumed to be transported with the parent material. As a result, exposures could be underestimated for decay products with transport properties that move them faster than the parent material. Table 5.2 lists the radionuclides for which this could occur. In this analysis, special runs were made to evaluate indices for the potential decay product inventories based on their properties. 
TABLE 5.2. Decay Products Potentially Moving Faster Than Parent Material

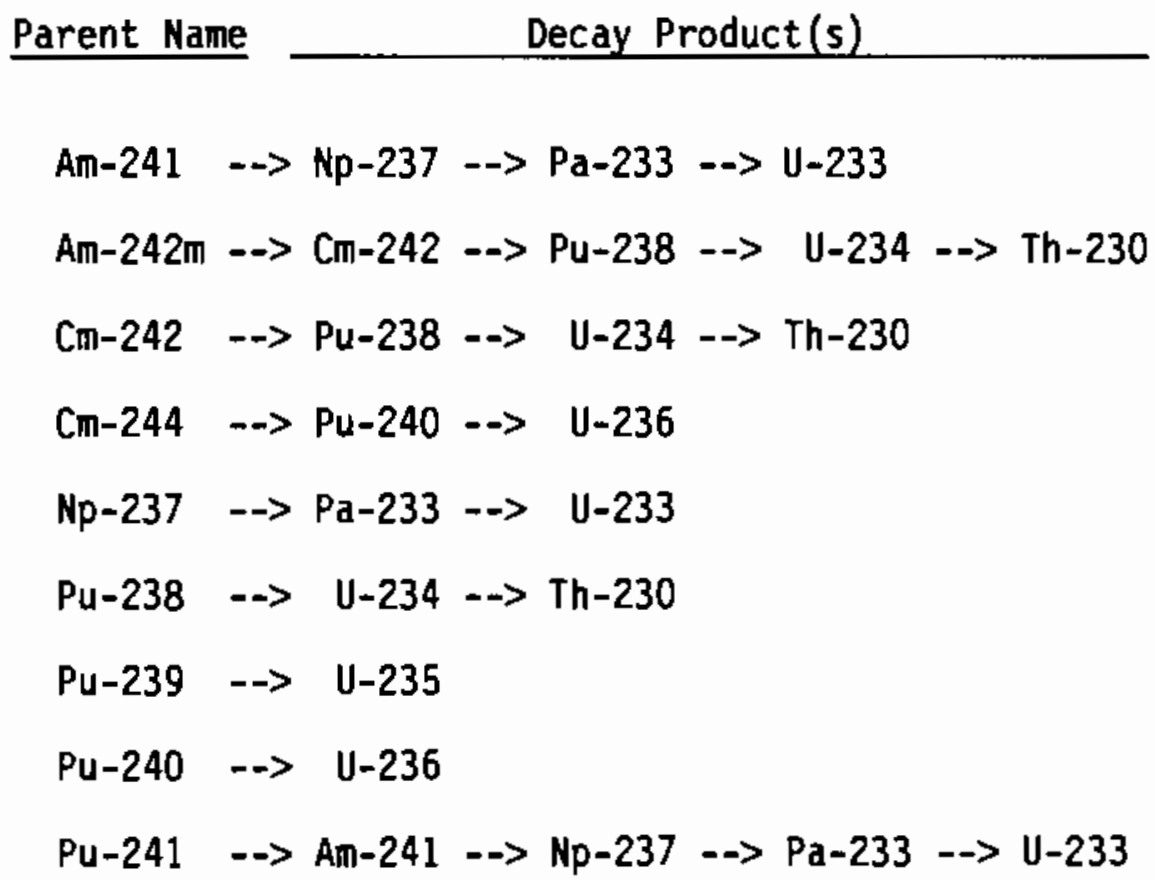




\subsection{ASSESSMENT RESULTS}

A large fraction of the constituents in SST waste had predicted concentrations of zero at the well and thus have little or no potential for impact. The results given below are for constituents with non-zero concentrations.

The best separation of the ranked constituents occurs for the highest assumed recharge rates. More non-zero concentrations are predicted for the highest recharge rate $(10.0 \mathrm{~cm} / \mathrm{yr})$ than for 0.5 and $1.0 \mathrm{~cm} / \mathrm{yr}$. As a result, $10.0 \mathrm{~cm} / \mathrm{yr}$ was selected as the recharge rate that the final rankings were based on. A listing of peak concentrations and their arrival times for all constituents in the hypothetical well are given for the $10.0 \mathrm{~cm} / \mathrm{yr}$ recharge rate in Appendix G.

As explained above, different ranking indices are used for carcinogenic and noncarcinogenic constituents. Constituents of importance based on health impacts for radiation exposure and chemical carcinogenic impacts are presented separately from chemicals with noncarcinogenic impacts. The chemicals are listed in two groups: 1) chemicals with an estimated inventory and 2) chemicals without an estimated inventory.

Figures 6.1 to 6.3 (figures referred to in Section 6.0 are found at the end of the section) summarize the Tank Farm Group A rankings for carcinogenic constituents for the three recharge rates. The relative rankings for radioactive materials are approximately equivalent to the appearance of niobium$93 \mathrm{M}$ at the bottom of the scale in the $10.0-\mathrm{cm} / \mathrm{yr}$ plot. Although all of the carcinogenic chemical impacts are too low to rank for $0.5-$ and $1.0-\mathrm{cm} / \mathrm{yr}$ recharge rates, arsenic (which is based on a $1 \%$ by weight inventory) appears at the top of the rankings for the $10.0-\mathrm{cm} / \mathrm{yr}$ recharge rate. Similar differences in the rankings were observed for the other tank farm groups for the $10.0-\mathrm{cm} / \mathrm{yr}$.

The appearance of constituents at the high recharge rate was primarily the result of decreasing the travel times to less than 10,000 years. To further investigate the effect of transport times, a $10.0-\mathrm{cm} / \mathrm{yr}$ recharge rate sensitivity run was made in which the $K_{d}$ values were reduced by a factor of 5. Figure 6.4 shows the rankings and peak concentration times for this 
analysis. The dependence on transport time is apparent (i.e., with a lower $K_{d}$ several additional constituents reach the receptor that did not before).

Figures 6.5 to 6.9 contain plots of the relative carcinogenic rankings for Tank Farm Groups B, C, S, T, and U. Figures 6.10 to 6.12 contain a summary of the Tank Farm Group A rankings for noncarcinogenic constituents for three recharge rates. Figure 6.13 shows the results of an reduced $K_{d}$ value on these rankings. Figures 6.14 to 6.18 contain plots of the relative noncarcinogenic rankings for Tank Farm Groups B, C, S, T, and U.

The highest radionuclide rankings at the tank farm groups occurred for carbon-14, technetium-99, uranium-238, uranium-235, and iodine-129. Uranium-234, uranium-233, thorium-229, and niobium-93M generally had lower rankings. Neptunium-237, protactinium-231, protactinium-233, thorium-229, and selenium-79 were added to the rankings in the transport sensitivity study for the cases with enhanced transport rates.

The highest rankings for noncarcinogenic chemicals for which estimated SST inventories were available occurred for cyanide, nitrite, nitrate, EDTA, fluoride, sodium, chromium VI, and sulfate. Nickel and iron ranked high for Tank Farm Groups S, T, and U. Silver and chloride ranked in the lower portion of the scale. The sensitivity study using enhanced transport rates resulted in the addition of zirconium to the rankings for Tank Farm Group $A_{\text {, }}$ a shift of iron from a low ranking to a high ranking, and some minor shifting of the ranking order of other constituents.

Antimony, mercury, and vanadium consistently appeared in the rankings for noncarcinogenic chemicals for which a $1 \%$ inventory was assumed. Also ranking are sulfate (Tank Farm Group S), cadmium (Tank Farm Groups $T$ and $U$ ), and copper (Tank Farm Group U). The sensitivity study using enhanced transport rates resulted in the appearance of copper and selenium in the rankings. Only arsenic appeared in any of the ranking results for carcinogenic chemicals for which a $1 \%$ inventory was assumed.

The rankings were found to change slightly over the possible range of recharge rates and transport rates. The effect is the addition of new constituents that are predicted to impact at a time near the end of the computational time period $(10,000$ years $)$. 


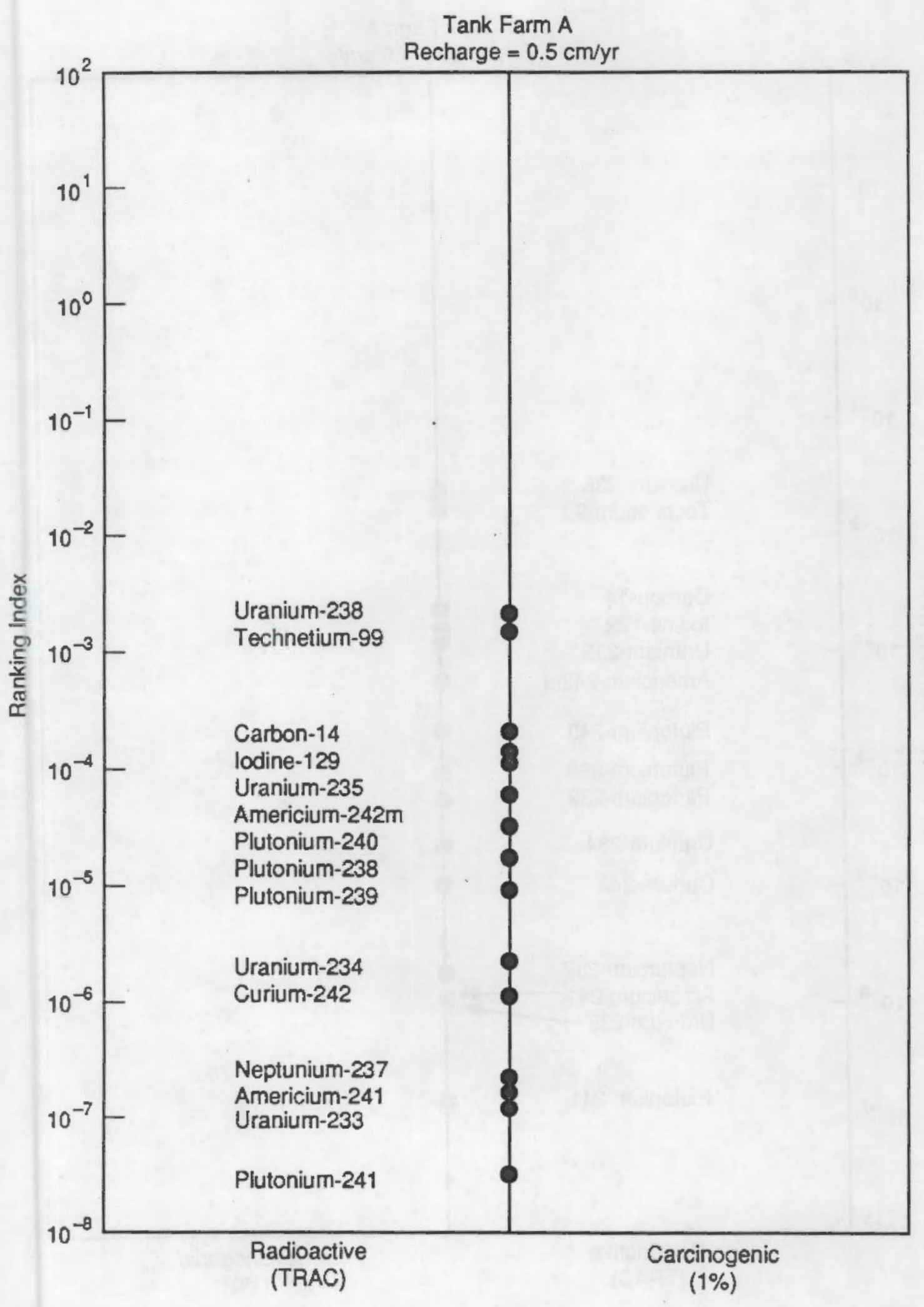

S8909112.1

FIGURE 6.1. Radioactive and Carcinogenic Chemicals Rankings for Tank Farm Group A with a Recharge Rate of $0.5 \mathrm{~cm} / \mathrm{yr}$ 
Tank Farm A

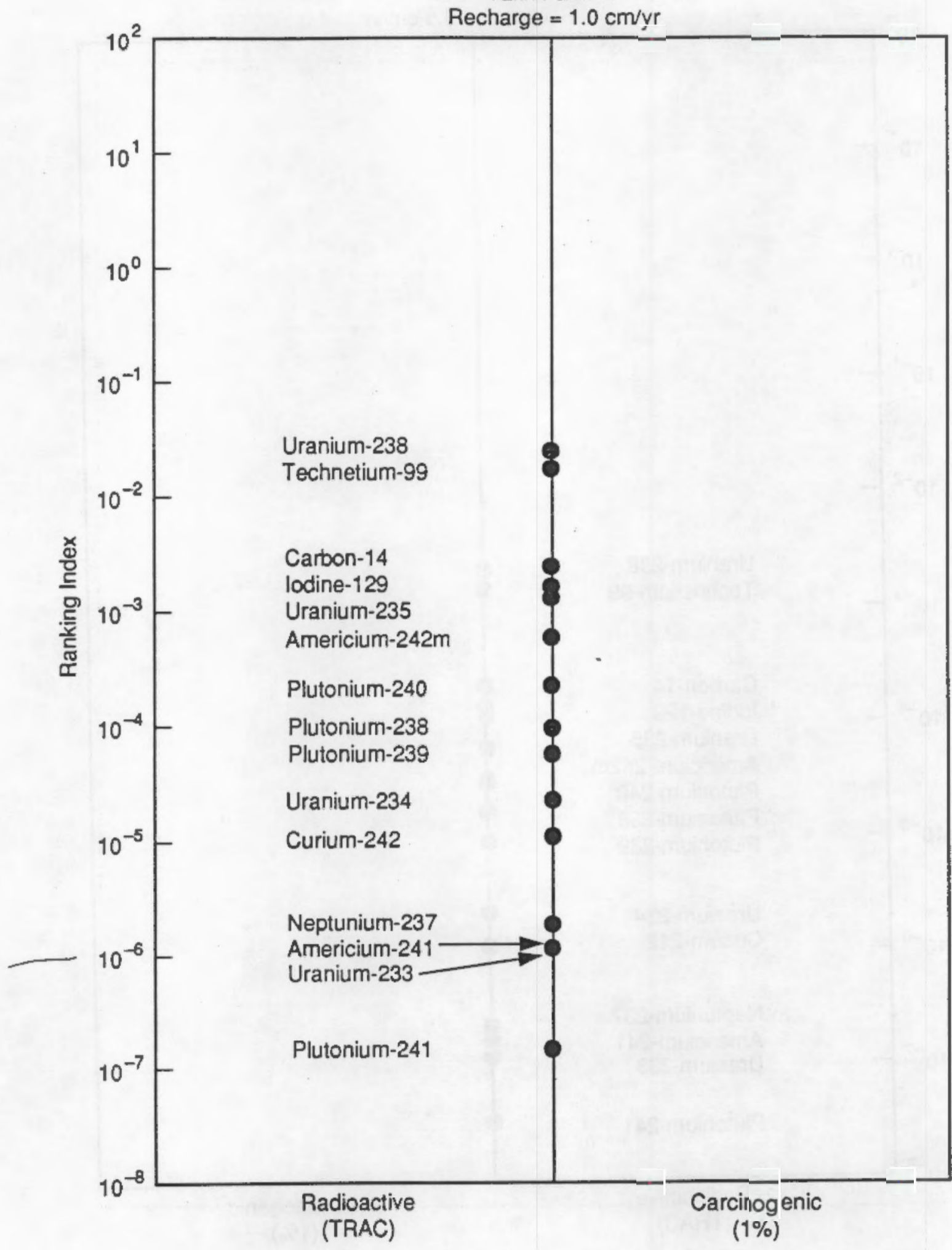

S8909112.2

FIGURE 6.2. Radioactive and Carcinogenic Chemicals Rankings for Tank Farm Group A with a Recharge Rate of $1.0 \mathrm{~cm} / \mathrm{yr}$ 
Tank Farm A

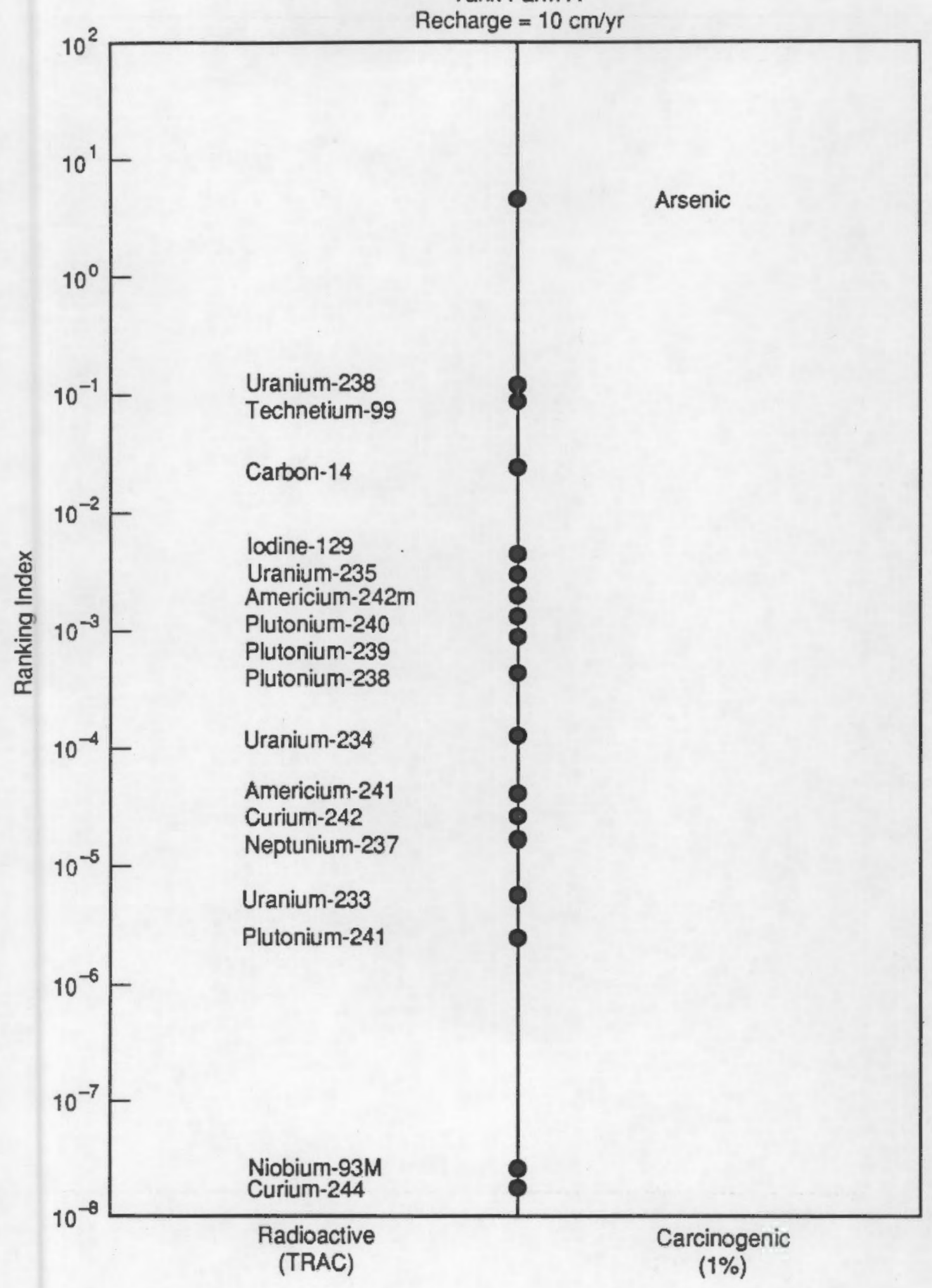

S8909112.3

FIGURE 6.3. Radioactive and Carcinogenic Chemicals Rankings for Tank Farm Group A with a Recharge Rate of $10.0 \mathrm{~cm} / \mathrm{yr}$ 

Tank Farm A

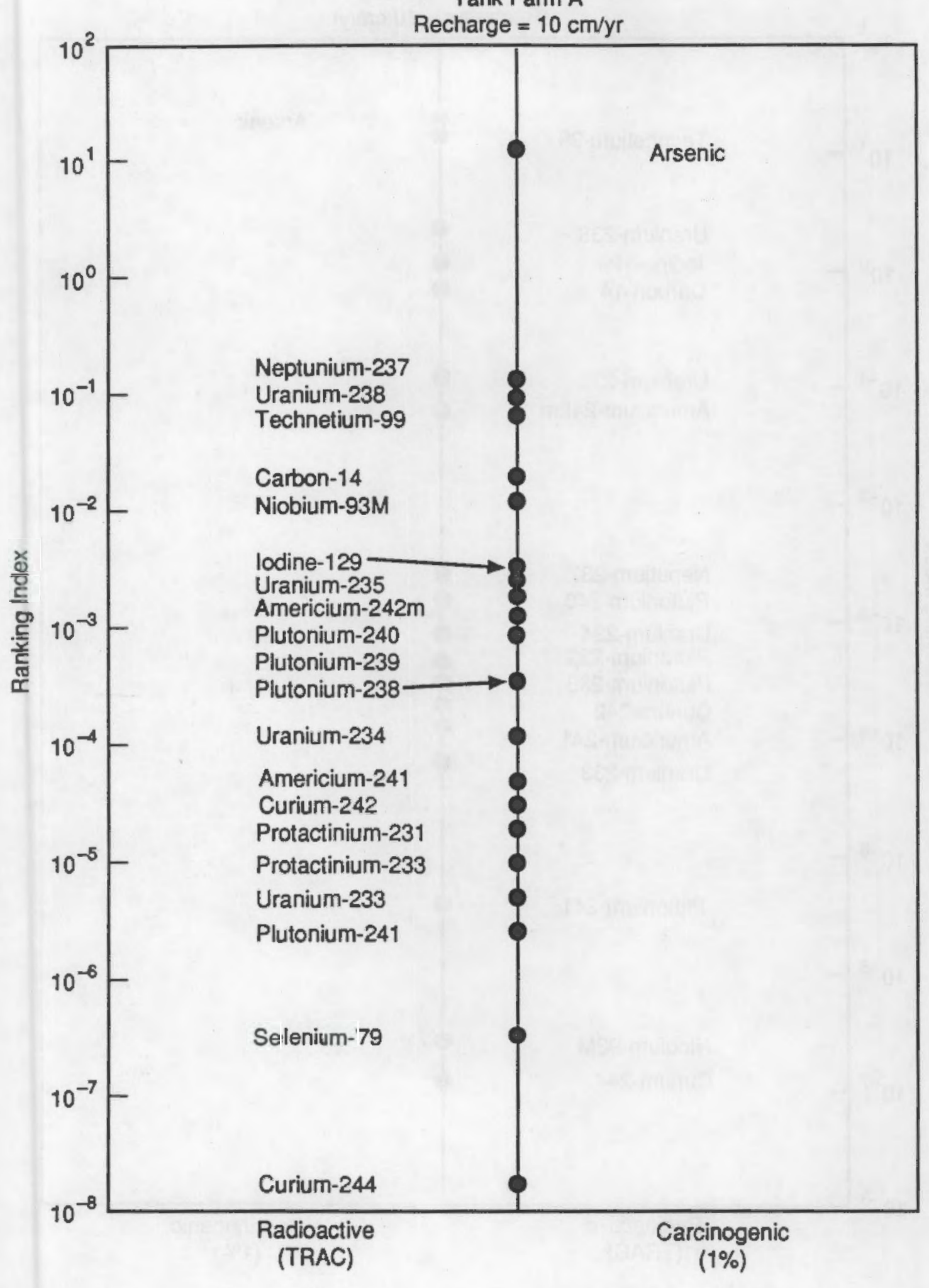

58909112.9

FIGURE 6.4. Kd Sensitivity Test Rankings for Radioactive and Carcinogenic Chemicals in Tank Farm Group A with a Recharge Rate of $10.0 \mathrm{~cm} / \mathrm{yr}$ 


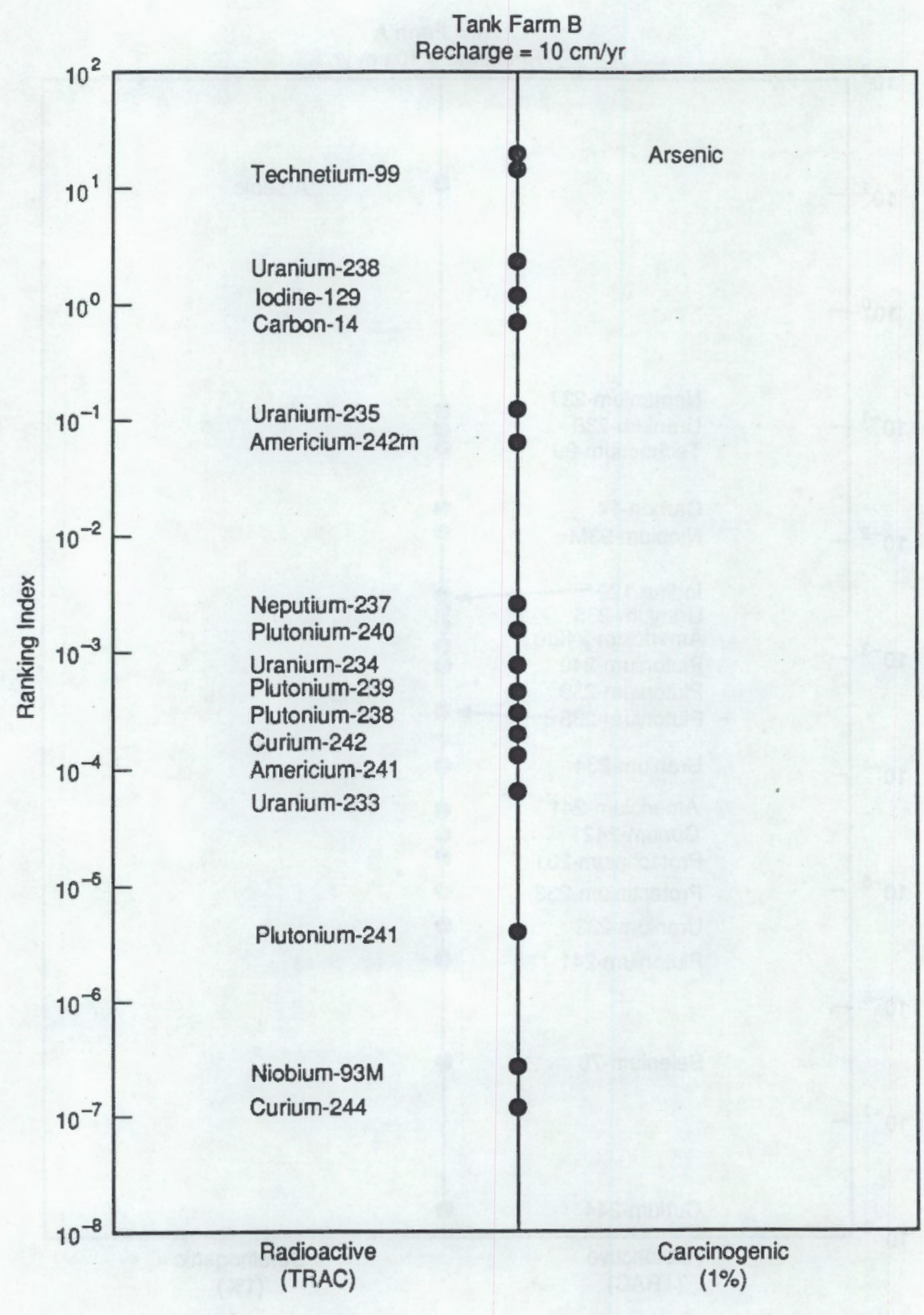

S8909112.4

FIGURE 6.5. Radioactive and Carcinogenic Chemicals Rankings for Tank Farm Group B with a Recharge Rate of $10.0 \mathrm{~cm} / \mathrm{yr}$ 
Tank Farm C

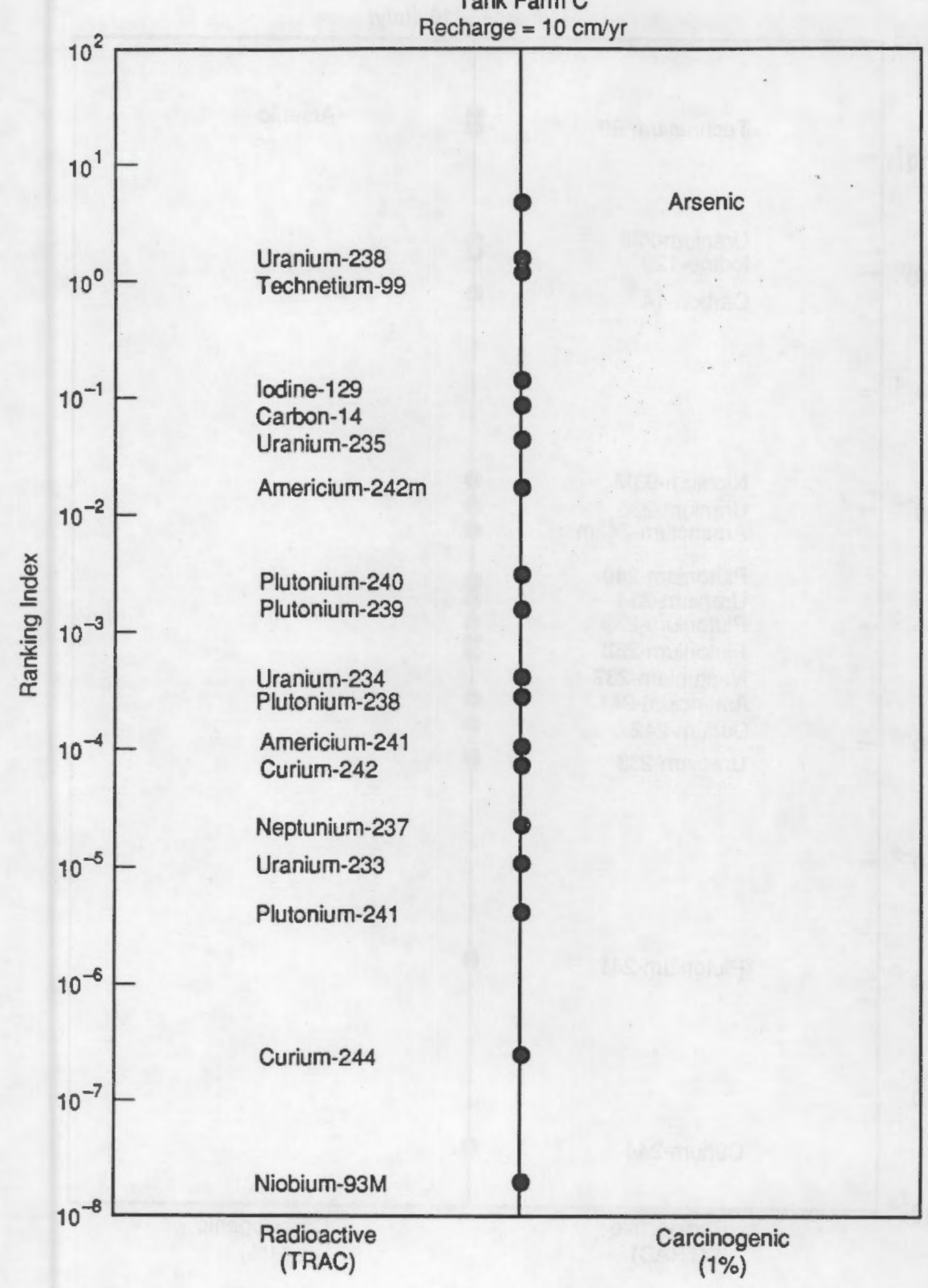

$\$ 8909112.5$

FIGURE 6.6. Radioactive and Carcinogenic Chemicals Rankings for Tank Farm Group C with a Recharge Rate of $10.0 \mathrm{~cm} / \mathrm{yr}$ 
Tank Farm S

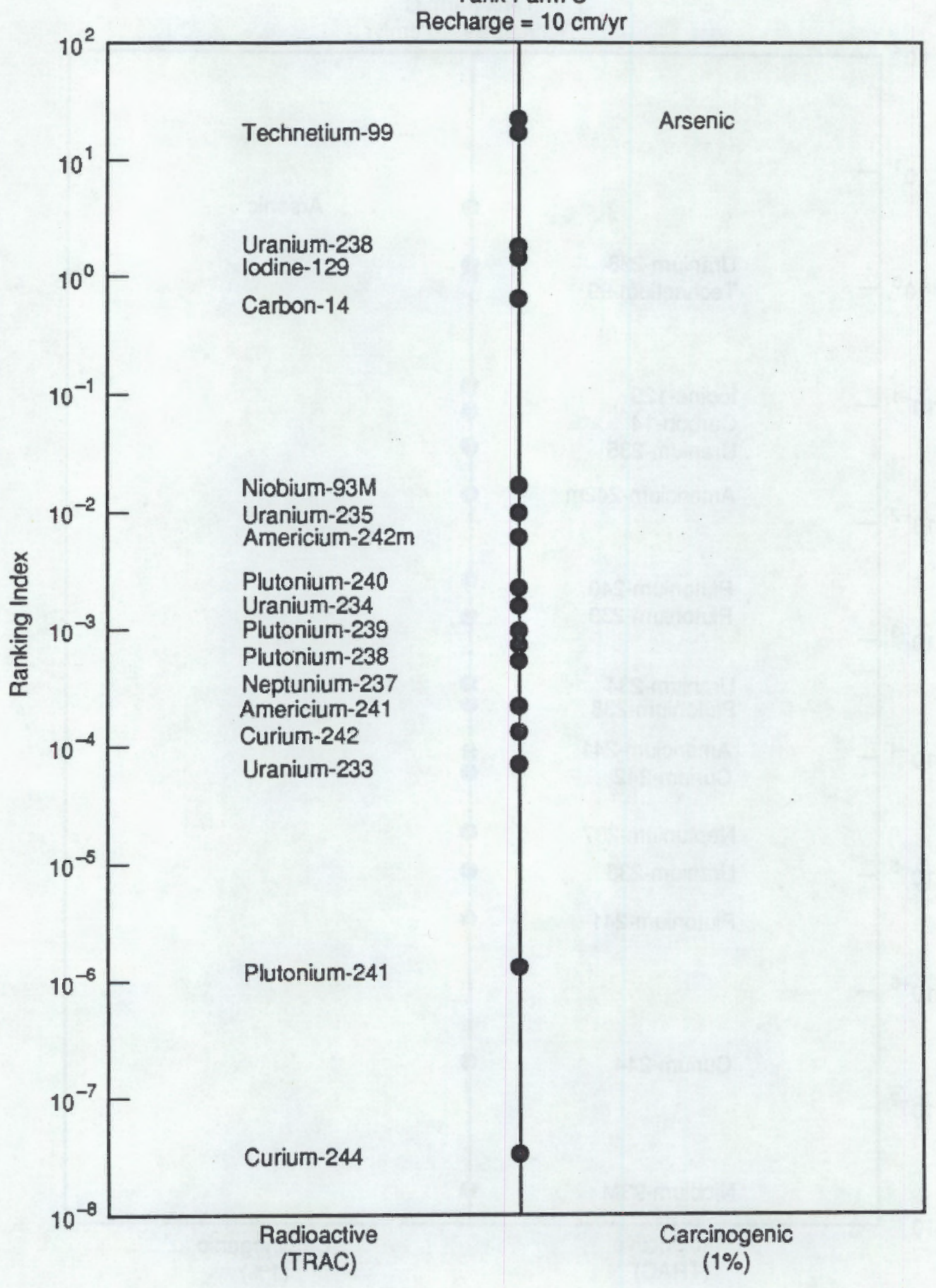

$\mathbf{S 8 9 0 9 1 1 2 . 6}$

FIGURE 6.7. Radioactive and Carcinogenic Chemicals Rankings for Tank Farm Group $S$ with a Recharge Rate of $10.0 \mathrm{~cm} / \mathrm{yr}$ 


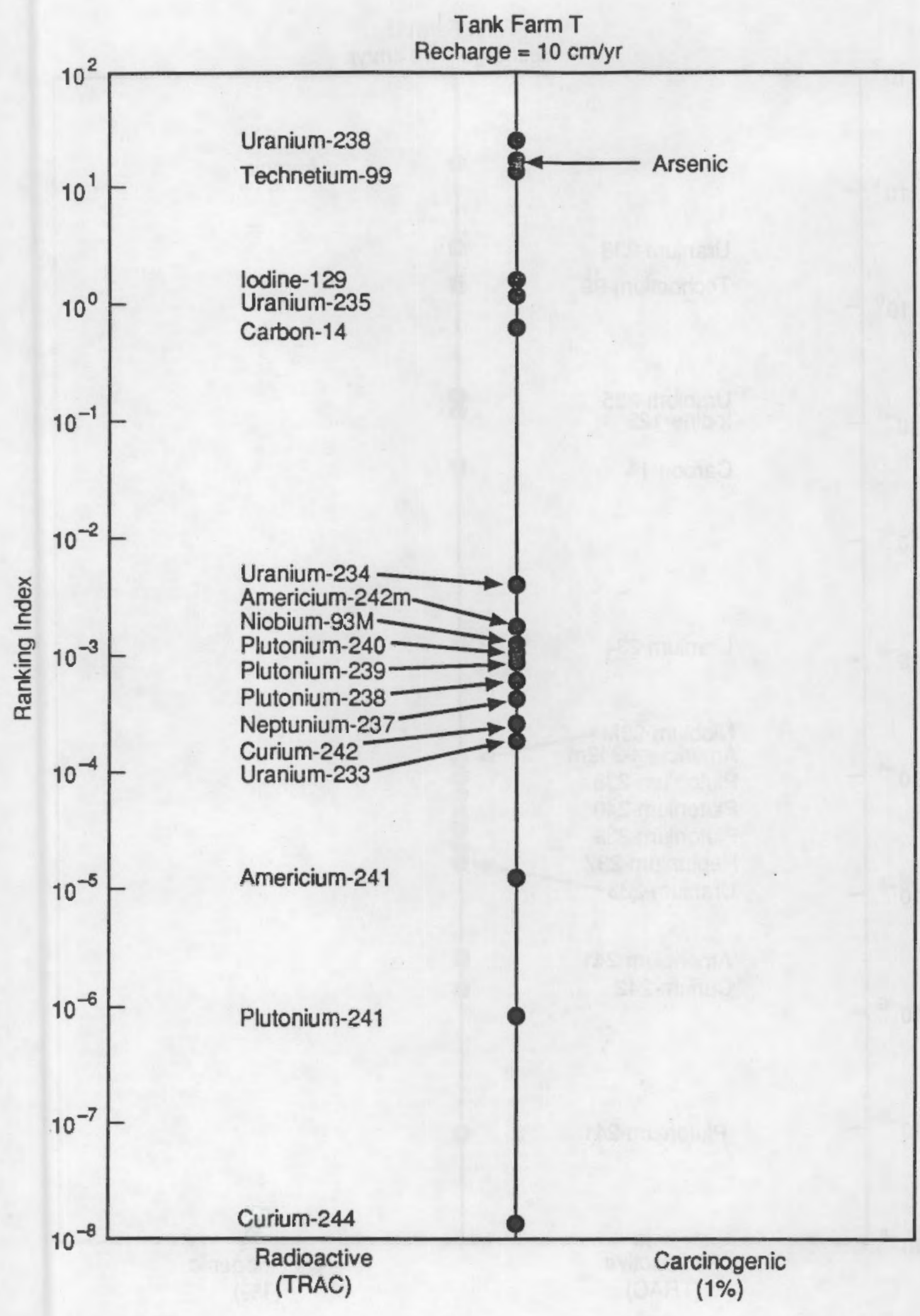

S8909112.7

FIGURE 6.8. Radioactive and Carcinogenic Chemicals Rankings for Tank Farm Group $T$ with a Recharge Rate of $10.0 \mathrm{~cm} / \mathrm{yr}$ 
Tank Farm U

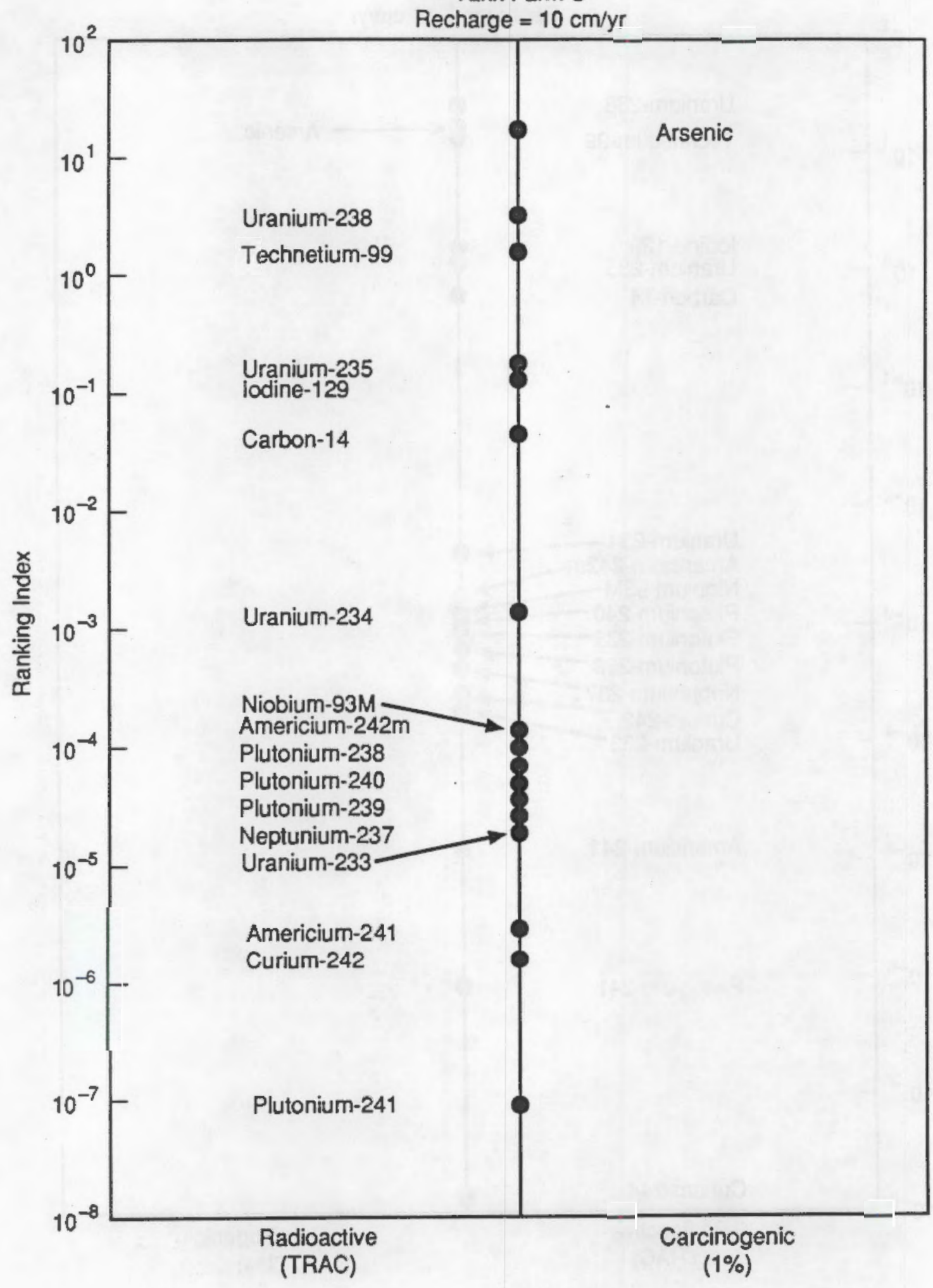

58909112.8

FIGURE 6.9. Radioactive and Carcinogenic Chemicals Rankings for Tank Farm Group U with a Recharge Rate of $10.0 \mathrm{~cm} / \mathrm{yr}$ 
Tank Farm A

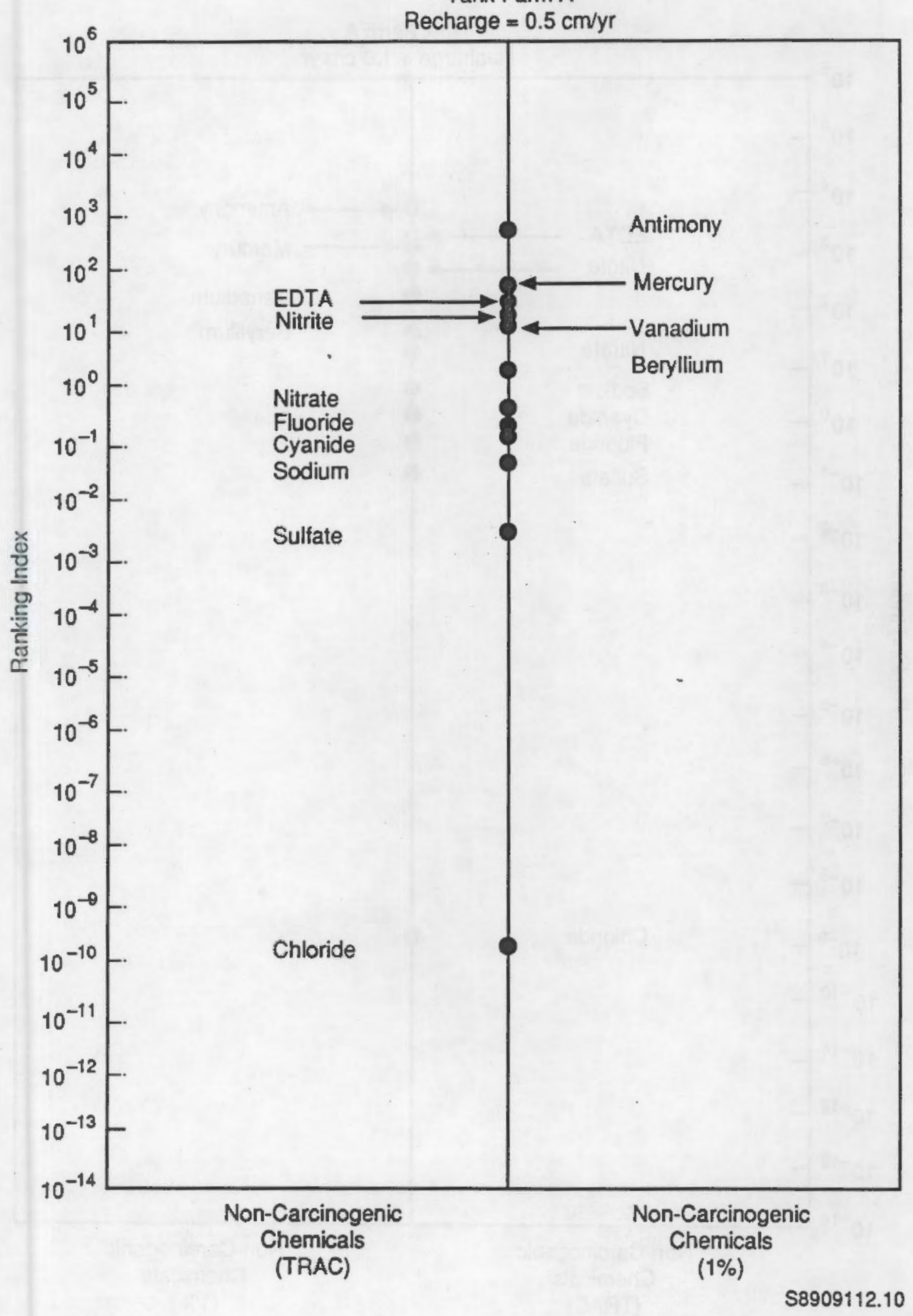

FIGURE 6.10. Noncarcinogenic Chemicals Rankings for Tank Farm Group A with a Recharge Rate of $0.5 \mathrm{~cm} / \mathrm{yr}$ 
Tank Farm A

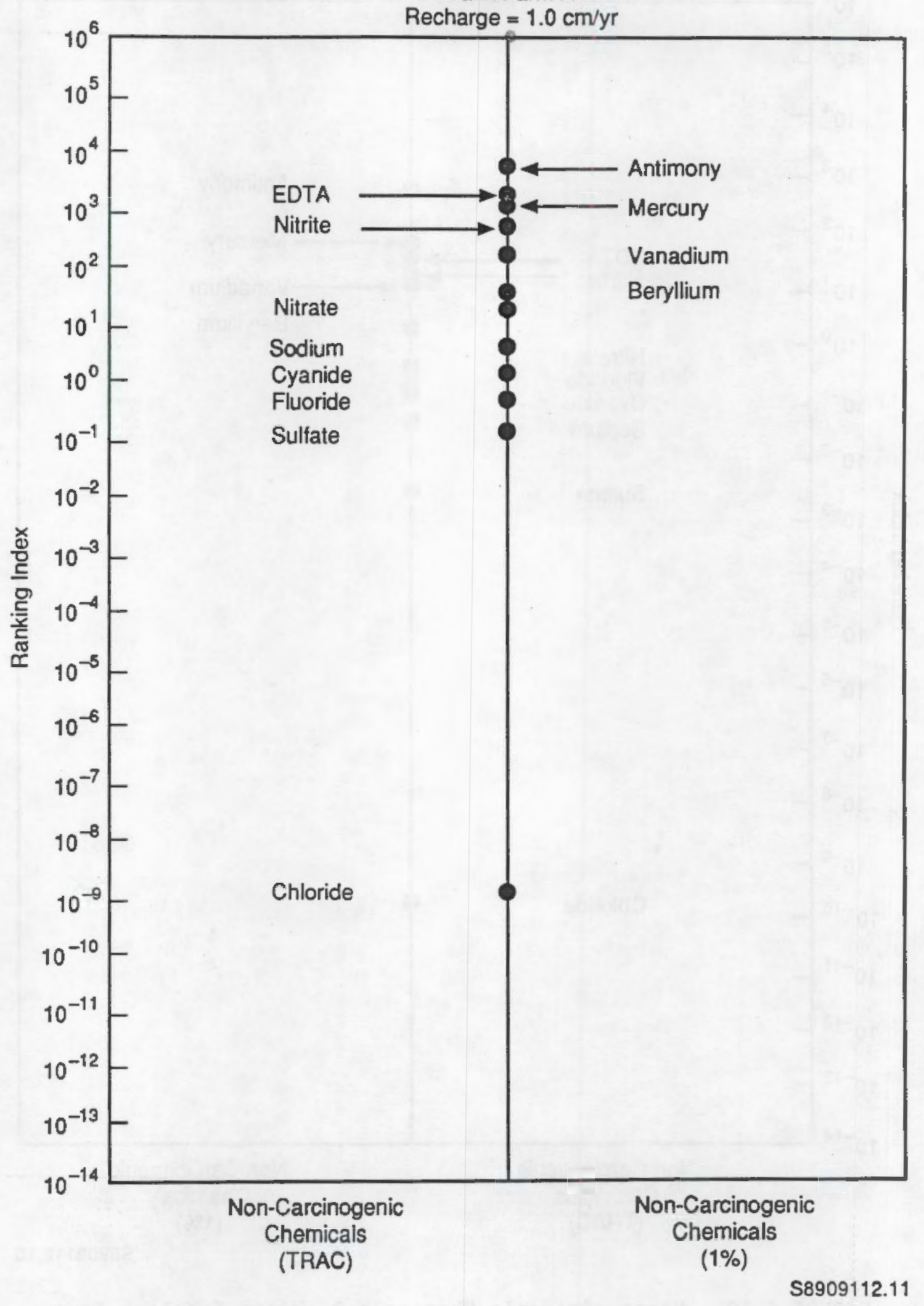

FIGURE 6.11. Noncarcinogenic Chemicals Rankings for Tank Farm Group A with a Recharge Rate of $1.0 \mathrm{~cm} / \mathrm{yr}$ 
Tank Farm A

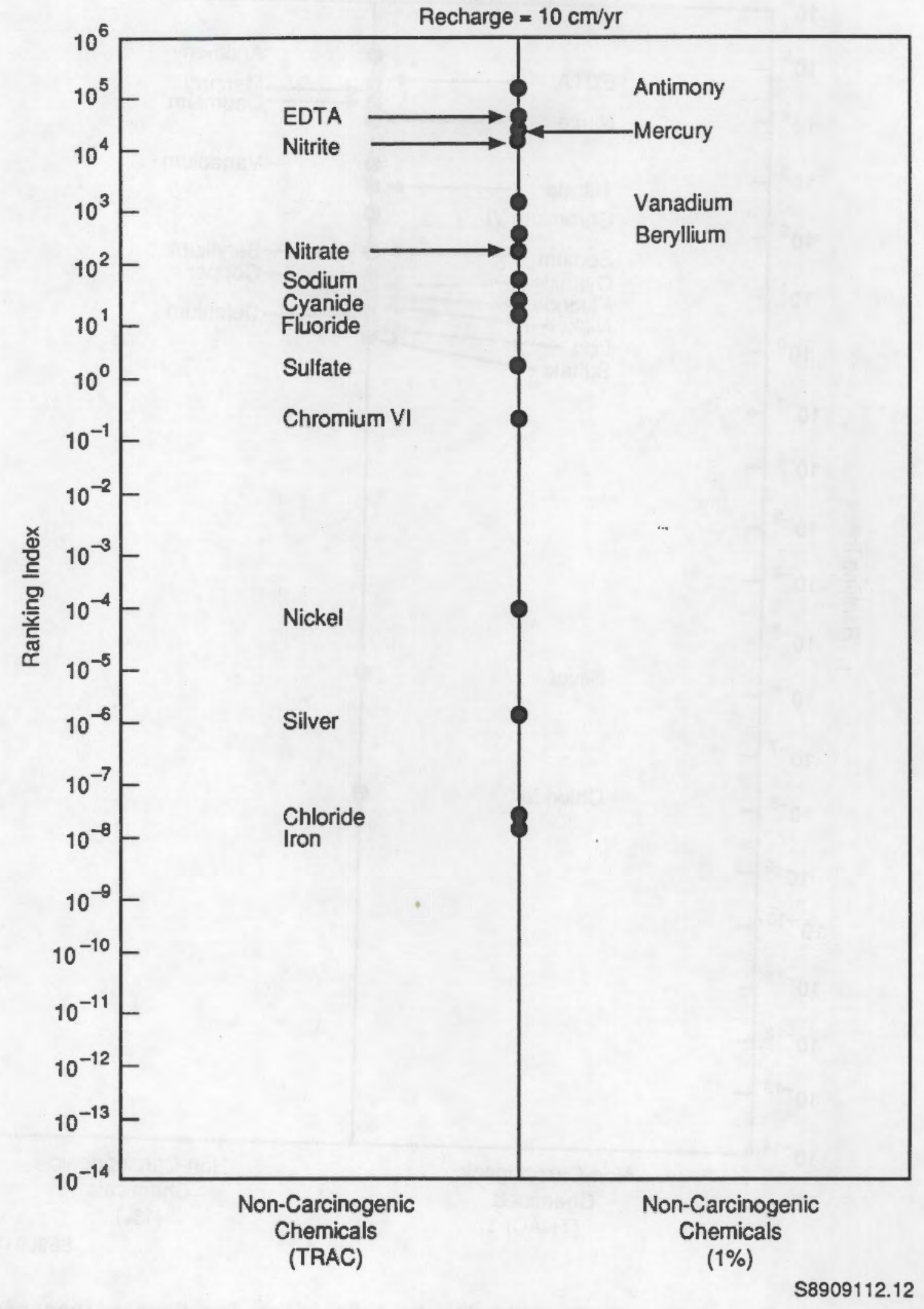

FIGURE 6.12. Noncarcinogenic Chemicals Rankings for Tank Farm Group A with a Recharge Rate of $10.0 \mathrm{~cm} / \mathrm{yr}$ 
Tank Farm A

Recharge $=10 \mathrm{~cm} / \mathrm{yr}$

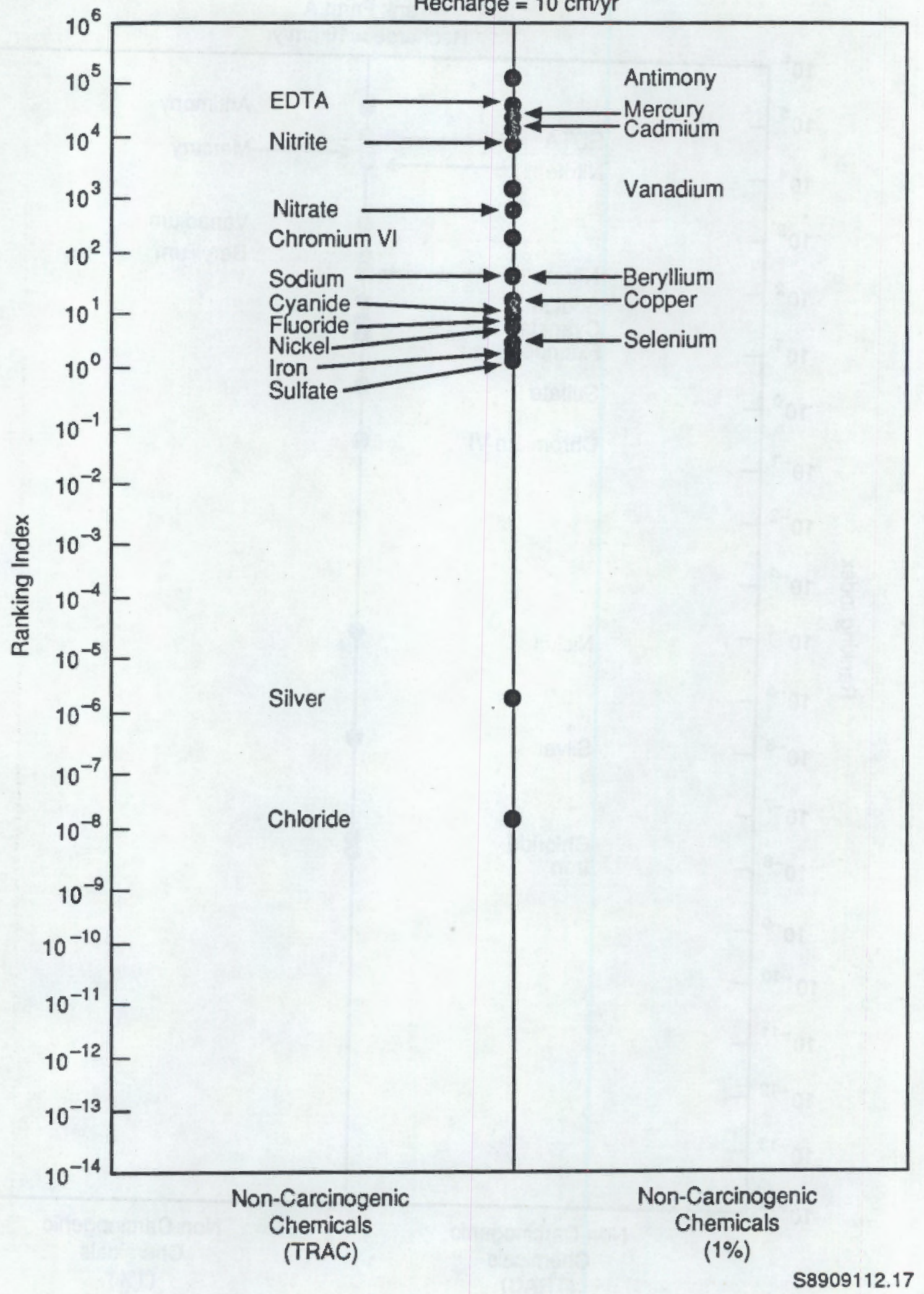

FIGURE 6.13. Kd Sensitivity Test Rankings for Noncarcinogenic Chemicals in Tank Farm Group A with a Recharge Rate of $10.0 \mathrm{~cm} / \mathrm{yr}$ 
Tank Farm B

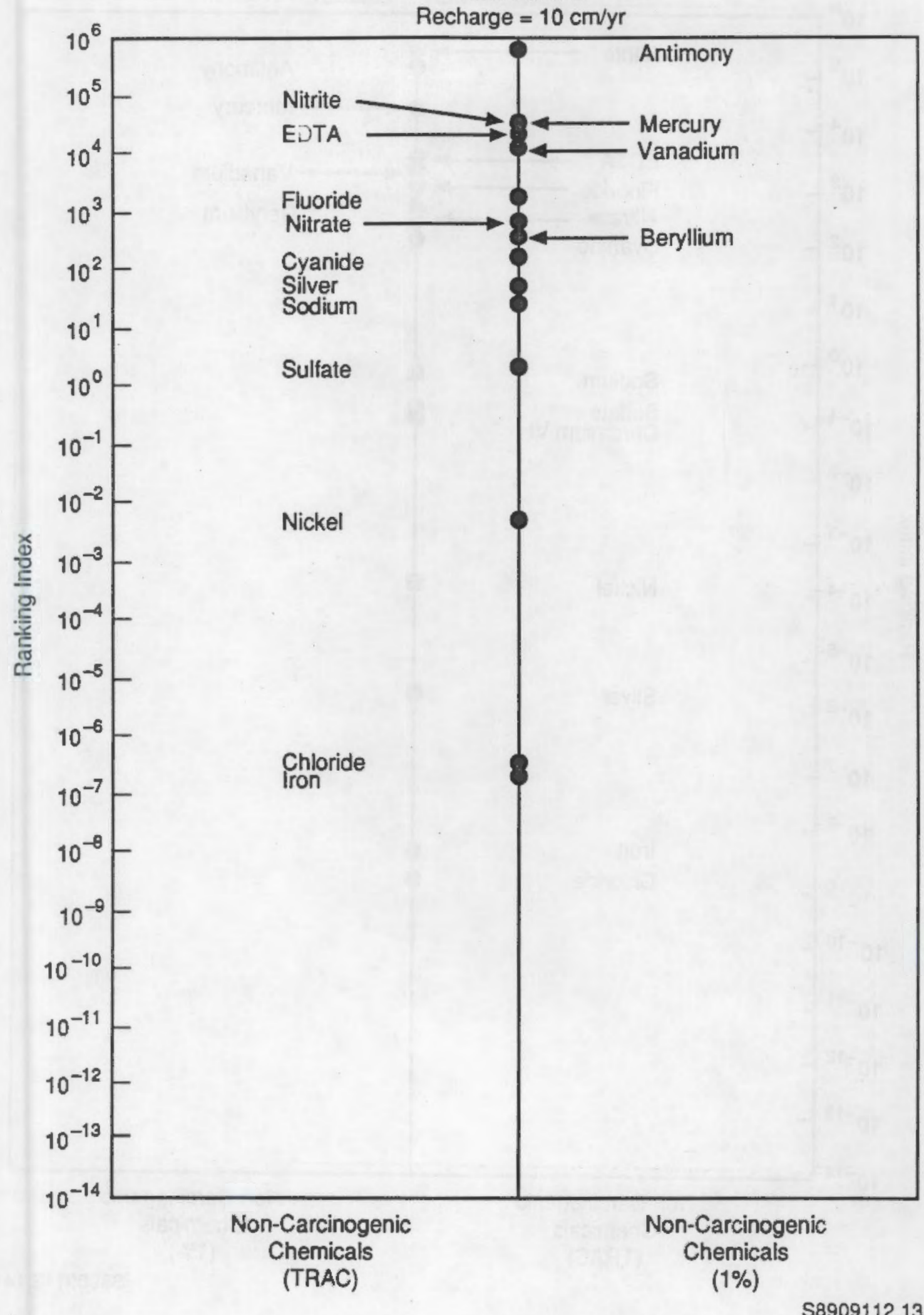

FIGURE 6.14. Noncarcinogenic Chemicals Rankings for Tank Farm Group B with a Recharge Rate of $10.0 \mathrm{~cm} / \mathrm{yr}$ 


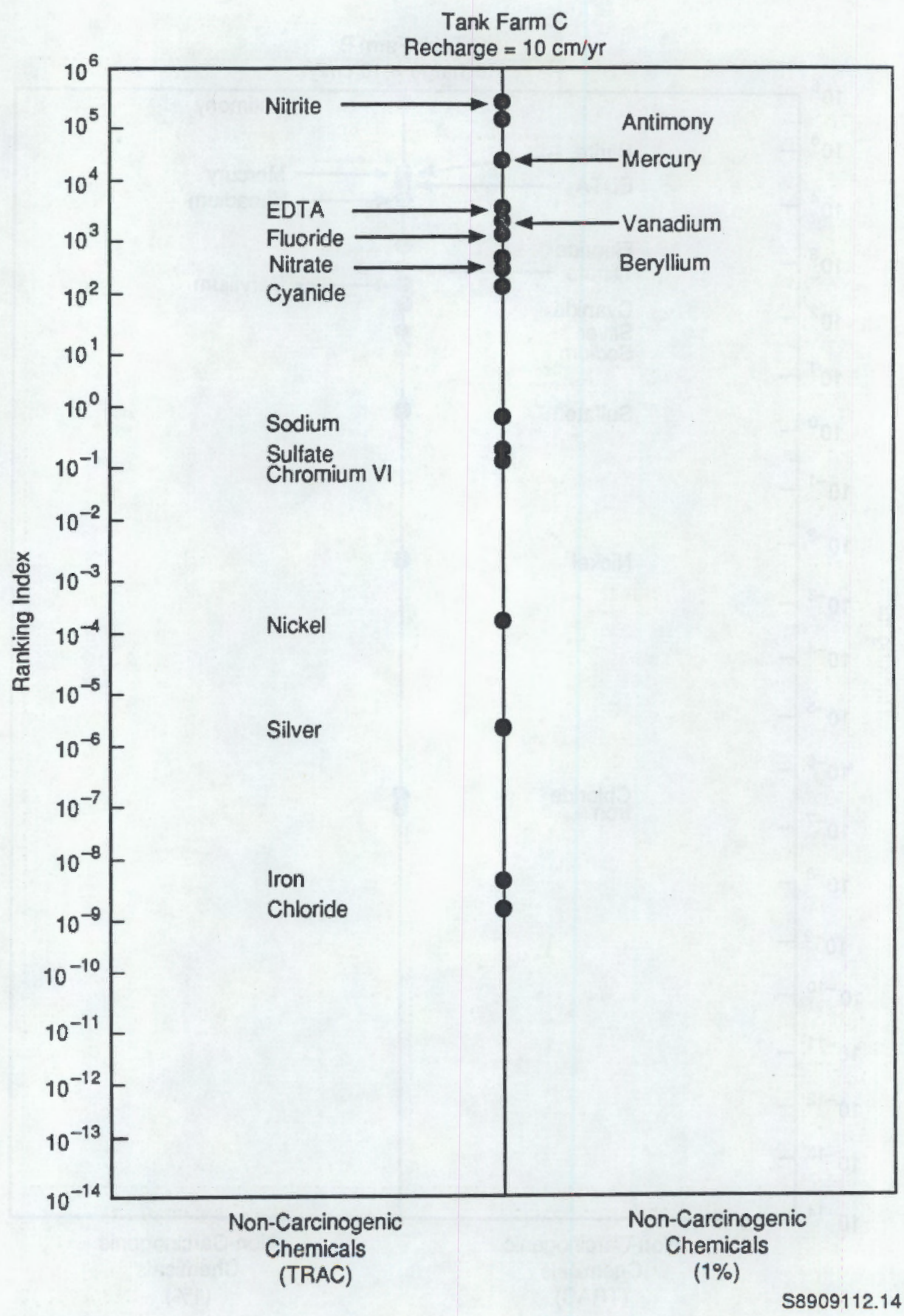

FIGURE 6.15. Noncarcinogenic Chemicals Rankings for Tank Farm Group C with a Recharge Rate of $10.0 \mathrm{~cm} / \mathrm{yr}$ 
Tank Farm S

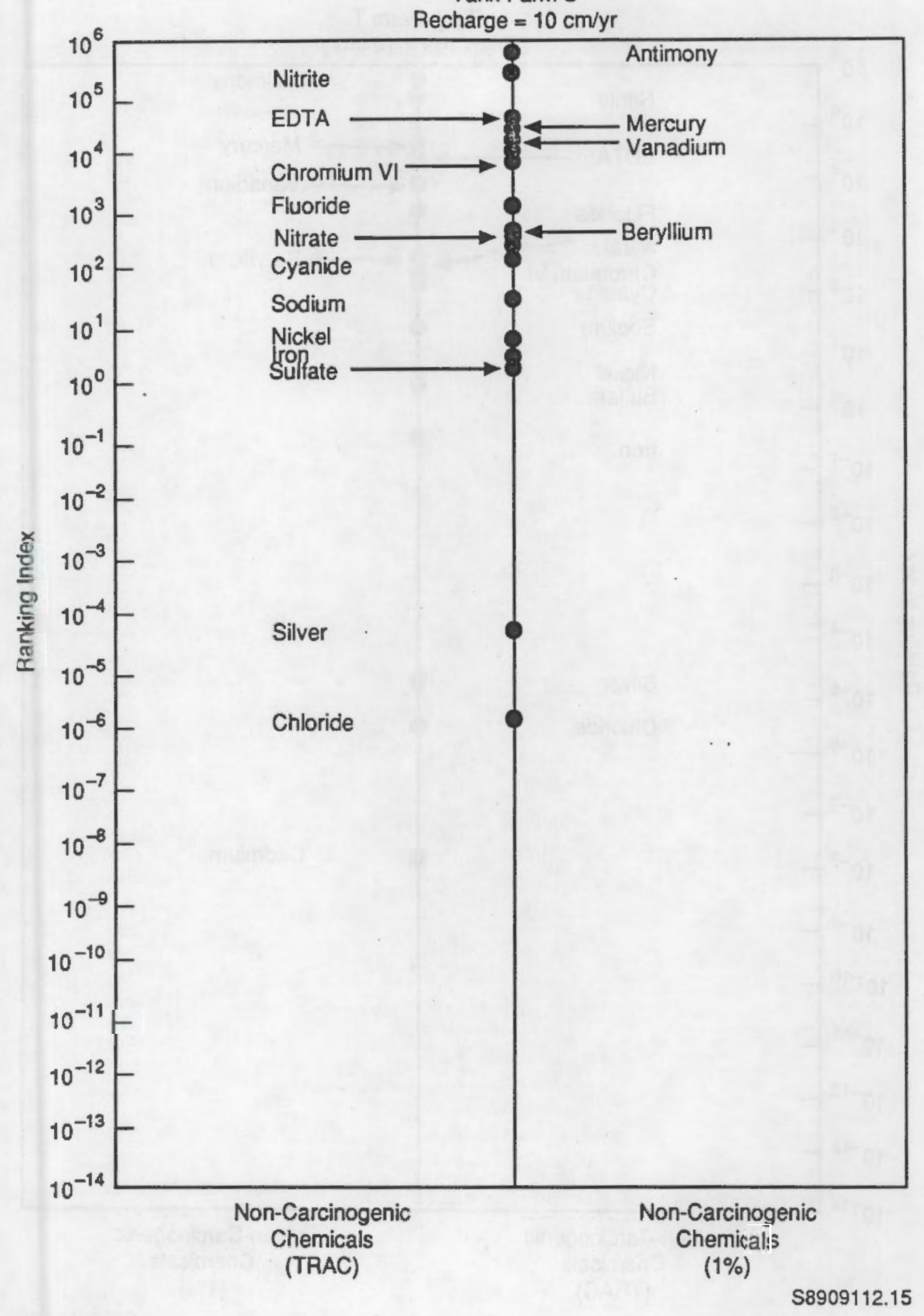

FIGURE 6.16. Noncarcinogenic Chemicals Rankings for Tank Farm Group $S$ with a Recharge Rate of $10.0 \mathrm{~cm} / \mathrm{yr}$ 


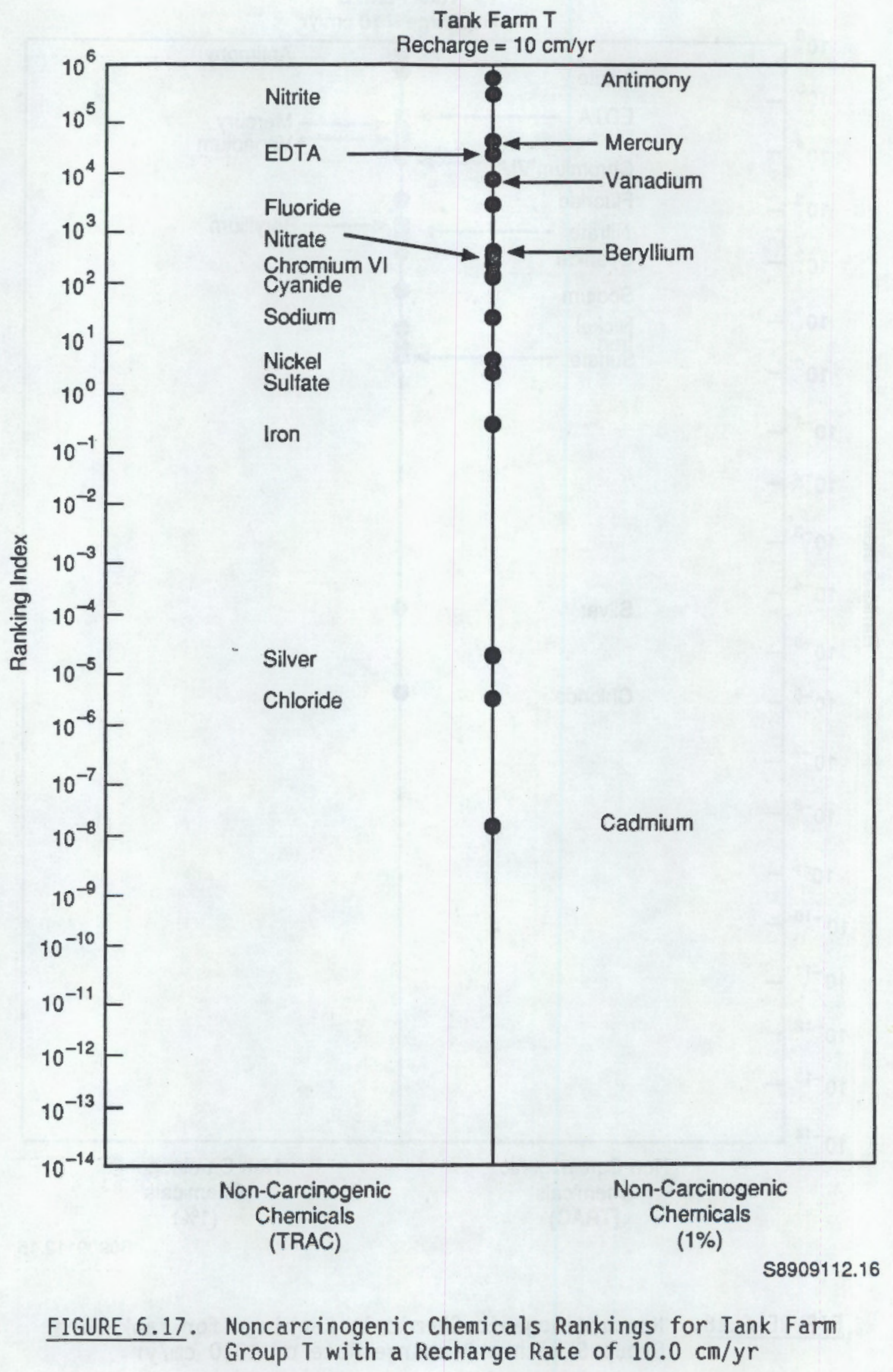


Tank Farm U

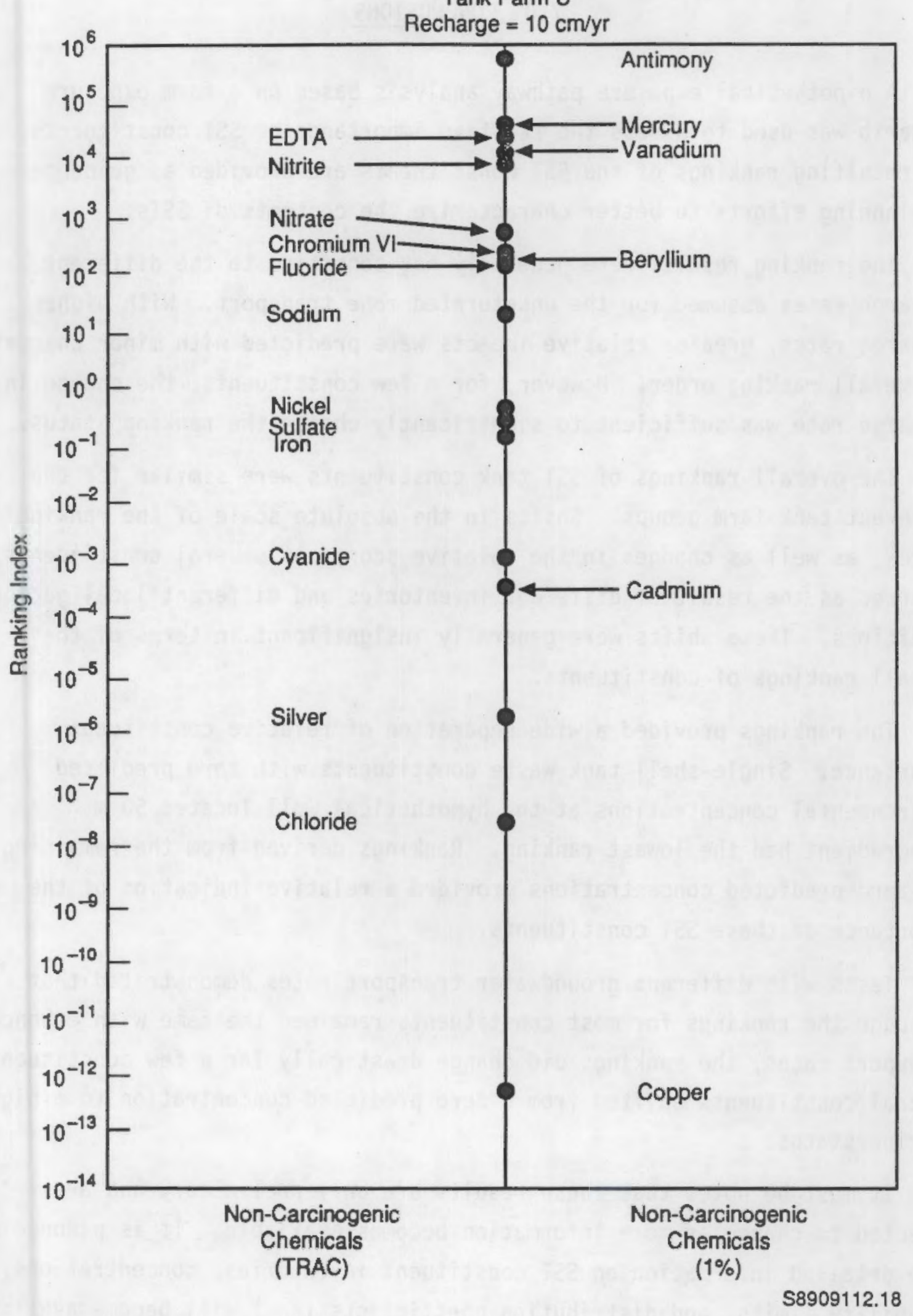

FIGURE 6.18. Noncarcinogenic Chemicals Rankings for Tank Farm Group U with a Recharge Rate of $10.0 \mathrm{~cm} / \mathrm{yr}$ 


\subsection{CONCLUSIONS}

A hypothetical exposure pathway analysis based on a farm exposure scenario was used to assess the relative importance of SST constituents. The resulting rankings of the SST constituents are provided as guidance in planning efforts to better characterize the contents of SSTs.

The ranking results were generally not sensitive to the different recharge rates assumed for the unsaturated zone transport. With higher recharge rates, greater relative impacts were predicted with minor changes in overall ranking order. However, for a few constituents, the change in recharge rate was sufficient to significantly change the ranking status.

The overall rankings of SST tank constituents were similar for the different tank farm groups. Shifts in the absolute scale of the ranking scores, as well as changes in the relative scores of several constituents, occurred as the result of different inventories and different local geologic conditions. These shifts were generally insignificant in terms of the overall rankings of constituents.

The rankings provided a wide separation of relative constituent importance. Single-shell tank waste constituents with zero predicted environmental concentrations at the hypothetical well located $50 \mathrm{~m}$ downgradient had the lowest ranking. Rankings derived from the remaining non-zero predicted concentrations provided a relative indication of the importance of these SST constituents.

Tests with different groundwater transport rates demonstrated that although the rankings for most constituents remained the same with enhanced transport rates, the rankings did change drastically for a few constituents. Several constituents shifted from a zero predicted concentration to a highranking status.

It must be noted that these results are only preliminary and are expected to change as more information becomes available. It is planned that more detailed information on SST constituent inventories, concentrations, solubility limits, and distribution coefficients (Kds) will become available. This information will allow for more representative results to be computed on the SST waste. 


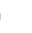




\subsection{REFERENCES}

Adams, M. R., L. Jensen, and W. W. Schulz. 1986. Preliminary Assessment of the TRAC Model as a Predictor of Radionucl ide Inventories. RH0-RE-EV-89P, Rockwel1 Hanford Operations, Rich1and, Washington.

Buh1, T. E., and W. R. Hansen. 1984. Estimating the Risks of Cancer Mortality and Genetic Defects Resulting from Exposures to Low Levels of Ionizing Radiation. LA-9893-MS, Los Alamos National Laboratory, Los Alamos, New Mexico.

CRC. 1988. CRC Handbook of Chemistry and Physics. CRC Press, Inc., West Pa7m Beach, Florida.

Droppo, J. G., D. L. Strenge, J. W. Buck, B. L. Hoopes, R. D. Brockhaus, M. B. Walter, and G. Whelan. 1989. Multimedia Environmental Pollutant Assessment System (MEPAS) Application Guidance_(Volume 2). PNL-7216 Vo 12 , Prepared for the Office of Environment, Safety, and Health, U.S. Department of Energy, Washington, D.C. by Pacific Northwest Laboratory, Richland, Washington.

DOE (U.S. Department of Energy). 1987. Final Environmental Statement for Disposal of Hanford Defense. High-Level Transuranic and Tank Wastes. DOE/EIS-0113, U.S. Department of Energy, Richland, Washington.

EPA. 1989. Risk Assessment Guidance for Superfund, Volume 1. Human Health Evaluation Manual (Part A). Interim Final, EPA/540/1-89/002, Office of Emergency and Remedial Response, U.S. Environmental Protection Agency, Washington D.C.

Fecht, K. R., and W. H. Price. 1977a. Granulometric Data 24l-A Tank Farm Monitoring Well Sediments. RH0-LD-11, Rockwell Hanford Operations, Richland, Washington.

Fecht, K. R., and W. H. Price. 1977b. Granulometric Data 241-AX Tank Farm Monitoring Well Sediments. RH0-LD-12, Rockwell Hanford Operations, Richland, Washington.

Fecht, K. R., and W. H. Price. 1977C. Granulometric Data 241-B Tank Farm Monitoring Well Sediments. RH0-LD-13, Rockwe1l Hanford Operations, Richland, Washington.

Fecht, K. R., and W. H. Price. 1977d. Granulometric Data 241-BX Tank Farm Monitoring Well Sediments. RHO-LD-14, Rockwe11 Hanford Operations, Richland, Washington.

Fecht, K. R., and W. H. Price. 1977e. Granulometric Data 24l-BY Tank Farm Monitoring Well Sediments. RHO-LD-15, Rockwell Hanford Operations, Richland, Washington. 
Fecht, K. R., and W. H. Price. 1977f. Granulometric Data 241-C Tank Farm Monitoring Well Sediments. RH0-LD-16, Rockwell Hanford Operations, Richland, Washington.

Fecht, K. R., and W. H. Price. 1977g. Granulometric Data 241-S Tank Farm Monitoring Well Sediments. RHO-LD-17, Rockwell Hanford Operations, Richland, Washington.

Fecht, K. R., and W. H. Price. 1977h. Granulometric Data 241-SX Tank Farm Monitoring Well Sediments. RH0-LD-18, Rockwell Hanford Operations, Richland, Washington.

Fecht, K. R., and W. H. Price. 1977i. Granulometric Data 241-T Tank Farm Monitoring Well Sediments. RHO-LD-19, Rockwell Hanford Operations, Richland, Washington.

Fecht, K. R., and W. H. Price. 1977j. Granulometric Data 241-TX Tank Farm Monitoring Well Sediments. RHO-LD-20, Rockwell Hanford Operations, Richland, Washington.

Fecht, K. R., and W. H. Price. 1977k. Granulometric Data 241-TY Tank Farm Monitoring Well Sediments. RHO-LD-21, Rockwell Hanford Operations, Richland, Washington.

Fecht, K. R., and W. H. Price. 19771. Granulometric Data 241-U Tank Farm Monitoring Well Sediments. RH0-LD-22, Rockwell Hanford Operations, Richland, Washington.

Gee, G. W. 1987. Recharge at the Hanford Site: Status Report. PNL-6403, Pacific Northwest Laboratory, Richland, Washington.

Graham, M. J., M. D. Hall, S. R. Strait, and W. R. Brown. 1981. Hydrology of the Separations Area. RHO-ST-42, Rockwell Hanford Operations, Richland, Washington.

Jaquish, R. E., and P. J. Mitche11. 1988. Environmental Monitoring at Hanford for 1987. PNL-6464, Pacific Northwest Laboratory, Richland, Washington.

Keller, J. F., M. G. Woodruff, A. J. Schmidt, P. L. Hendrickson, and K. B. Selby. 1989. Regulatory Reguirements Important to Hanford Single-Shell Tank Disposal Decisions. PNL-6821, Pacific Northwest Laboratory, Richland, Washington.

Morgan, L. G., W. W. Schultz, M. R. Adams, and K. W. Owens. 1988. Summary of Single-Shell Tank Waste Characterization: 1985-1987. WHC-EP-0075, Westinghouse Hanford Company, Richland, Washington.

NAS. 1980. The Effects on Populations of Exposure to Low Levels of Ionizing Radiation. National Academy of Sciences Committee on the Biological Effects of Ionizing Radiations, National Research Council, Washington, D.C. 
Price, W. H., and K. R. Fecht. 1976a. Geology of the 241-A Tank Farm. ARH-LD-127, Atlantic Richfield Hanford Company, Richland, Washington.

Price, W. H., and K. R. Fecht. 1976b. Geology of the 241-AX Tank Farm. ARH-LD-128, Atlantic Richfield Hanford Company, Richland, Washington.

Price, W. H., and K. R. Fecht. 1976c. Geology of the 241-B Tank Farm. ARH-LD-129, Atlantic Richfield Hanford Company, Richland, Washington.

Price, W. H., and K. R. Fecht. 1976d. Geology of the 241-BX Tank Farm. ARH-LD-130, Atlantic Richfield Hanford Company, Richland, Washington.

Price, W. H., and K. R. Fecht. 1976e. Geology of the 241-BY Tank Farm. ARH-LD-131, Atlantic Richfield Hanford Company, Richland, Washington.

Price, W. H., and K. R. Fecht. 1976f. Geology of the 241-C Tank Farm. ARH-LD-132, Atlantic Richfield Hanford Company, Richland, Washington.

Price, W. H., and K. R. Fecht. 1976g. Geology of the 241-S Tank Farm. ARH-LD-133, Atlantic Richfield Hanford Company, Richland, Washington.

Price, W. H., and K. R. Fecht. 1976h. Geology of the 241-SX Tank Farm. ARH-LD-134, Atlantic Richfield Hanford Company, Richland, Washington.

Price, W. H., and K. R. Fecht. 1976i. Geology of the 241-T Tank Farm. ARH-LD-135, Atlantic Richfield Hanford Company, Richland, Washington.

Price, W. H., and K. R. Fecht. 1976j. Geology of the 241-TX Tank Farm. ARH-LD-136, Atlantic Richfield Hanford Company, Richland, Washington.

Price, W. H., and K. R. Fecht. 1976k. Geology of the 241-TY Tank Farm. ARH-LD-137, Atlantic Richfield Hanford Company, Richland, Washington.

Price, W. H., and K. R. Fecht. 19761. Geology of the 241-U Tank Farm. AHR-LD-138, Atlantic Richfield Hanford Company, Richland, Washington.

Schatz, A. L., and M. D. McElroy. 1988. Ground-Water Maps of the Hanford Site Separations Area June 1988. WHC-EP-0142-1, Westínghouse Hanford Company, Richland, Washington.

Schulz, W. W. 1978. Removal of Radionuclides from Hanford Defense Waste Solutions. RH0-SA-51, Rockwell Hanford Operations, Richland, Washington.

Serne, R. J., and M. I. Wood. 1990. Hanford Waste-Form Release and Sediment Interaction. PNL-7297, Pacific Northwest Laboratory, Richland, Washington.

Sewart, G. H., W. T. Farris, D. G. Huizenga, A. H. McMakin, G. P. Streile, and R. L. Treat. 1987. Long-Term Performance Assessment of Grouted Phosphate/Sulfate Waste from N Reactor 0perations, PNL-6152, Pacific Northwest Laboratory, Richland, Washington. 
Strenge, D. L., and S. R. Peterson. 1989. Chemical Data Bases as Applied to the U.S. Department of Energy Environmental Survey. PNL-7145, Pacific Northwest Laboratory, Richland, Washington.

Tallman, A. M., K. R. Fecht, M. C. Marratt, and G. V. Last. 1979. Geology of the Separation Areas, Hanford Site, South-Central Washington. RHO-ST-23, Rockwell Hanford Operations, Richland, Washington.

Weiss, R. L. 1986. TY Tank Farm Waste Characterization Data. RHO-WM-TI-1P, Rockwell Hanford Operations, Richland, Washington.

Whelan, G., D. L. Strenge, J. G. Droppo, Jr. and B. L. Steelman. 1987.

The Remedial Action Priority System (RAPS): Mathematical Formulations.

PNL-6200, Pacific Northwest Laboratory, Richland, Washington.

Winters, W. I., L. Jensen, L. M. Sasaki, R. L. Weiss, A. R. Keller, A. J. Schmidt, and M. G. Woodruff. 1989. Waste Characterization Plan for the Hanford Site Single-Shell Tanks. WHC-EP-D210, Westinghouse Hanford Company, Richland, Washington. 
APPENDIX A

TRAC RADIONUCLIDE INVENTORY FOR SINGLE-SHELL TANK FARMS 
APPENDIX A

TRAC RADIONUCLIDE INVENTORY FOR SINGLE-SHELL TANK FARMS (a)

IABLE A.1. TRAC Radionuclide Inventory for Tank Farm Group A

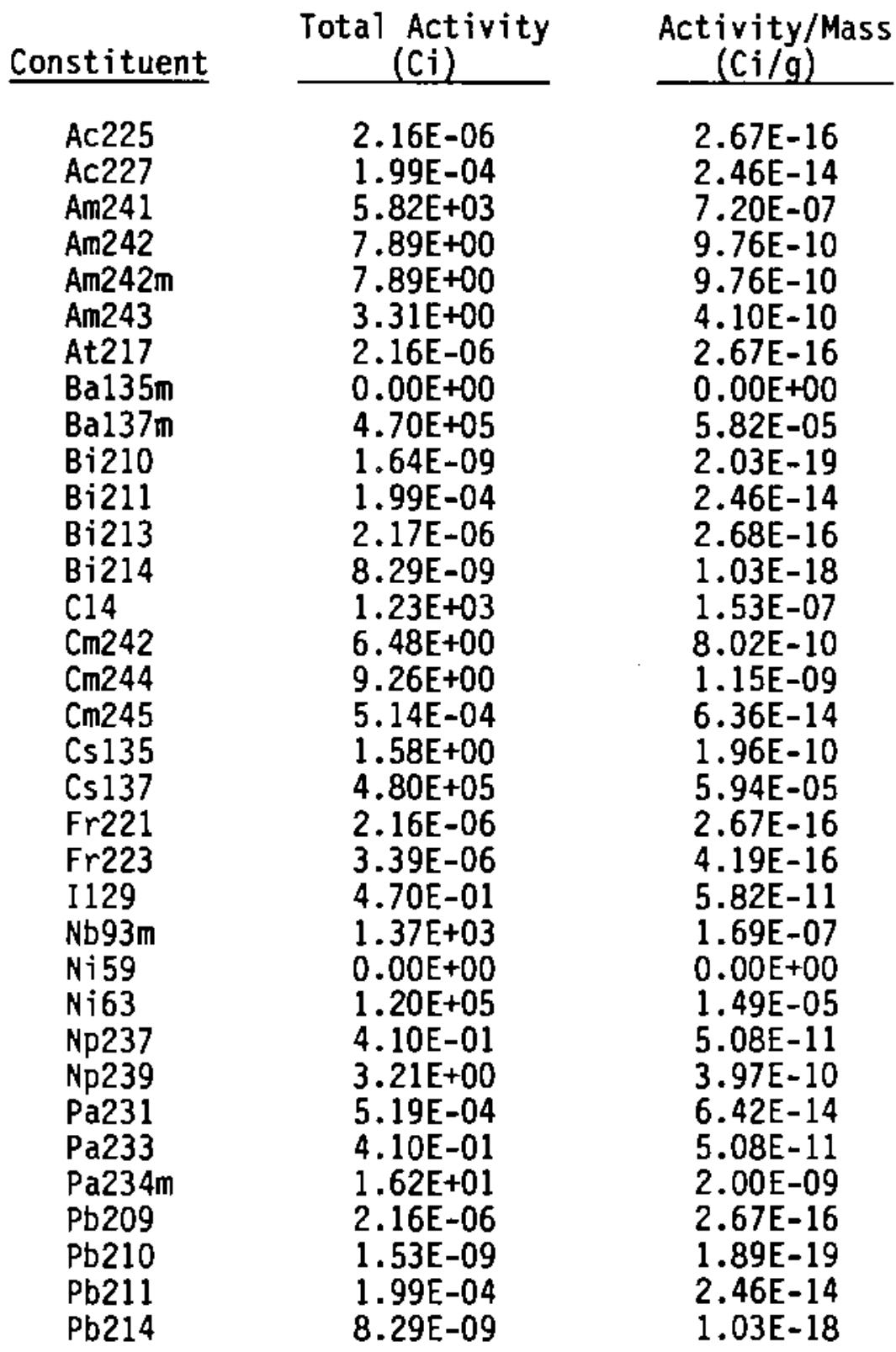


TABLE A.1. (contd)

\begin{tabular}{|c|c|c|}
\hline Constituent & $\begin{array}{c}\text { Total Activity } \\
\text { (Ci) }\end{array}$ & $\begin{array}{l}\text { Activity/Mass } \\
(\mathrm{Ci} / \mathrm{g})\end{array}$ \\
\hline $\begin{array}{l}\text { Pd107 } \\
\text { Po210 } \\
\text { Po213 } \\
\text { Po214 } \\
\text { Po215 } \\
\text { Po218 } \\
\text { Pu238 } \\
\text { Pu239 } \\
\text { Pu240 } \\
\text { Pu241 } \\
\text { Ra223 } \\
\text { Ra225 } \\
\text { Ra226 } \\
\text { Ru106 } \\
\text { Sb126 } \\
\text { Sb126m } \\
\text { Se79 } \\
\text { Sm151 } \\
\text { Sn126 } \\
\text { Sr90 } \\
\text { Tc99 } \\
\text { Th227 } \\
\text { Th229 } \\
\text { Th230 } \\
\text { Th231 } \\
\text { Th233 } \\
\text { Th234 } \\
\text { T1207 } \\
\text { U233 } \\
\text { U234 } \\
\text { U235 } \\
\text { U238 } \\
\text { Y90 } \\
\text { Zr93 }\end{array}$ & $\begin{array}{l}9.40 \mathrm{E}-01 \\
1.52 \mathrm{E}-09 \\
2.16 \mathrm{E}-06 \\
1.09 \mathrm{E}-08 \\
1.99 \mathrm{E}-04 \\
8.29 \mathrm{E}-09 \\
2.29 \mathrm{E}+02 \\
4.90 \mathrm{E}+03 \\
1.37 \mathrm{E}+03 \\
1.44 \mathrm{E}+04 \\
1.99 \mathrm{E}-04 \\
2.16 \mathrm{E}-06 \\
8.29 \mathrm{E}-09 \\
2.48 \mathrm{E}+01 \\
2.49 \mathrm{E}+02 \\
2.49 \mathrm{E}+02 \\
9.50 \mathrm{E}+00 \\
2.50 \mathrm{E}+05 \\
2.49 \mathrm{E}+02 \\
2.30 \mathrm{E}+07 \\
3.20 \mathrm{E}+02 \\
1.97 \mathrm{E}-04 \\
2.16 \mathrm{E}-06 \\
2.35 \mathrm{E}-06 \\
7.39 \mathrm{E}-01 \\
0.00 \mathrm{E}+00 \\
1.62 \mathrm{E}+01 \\
1.99 \mathrm{E}-04 \\
1.17 \mathrm{E}-03 \\
2.05 \mathrm{E}-02 \\
7.39 \mathrm{E}-01 \\
1.62 \mathrm{E}+01 \\
2.30 \mathrm{E}+07 \\
2.18 \mathrm{E}+03\end{array}$ & $\begin{array}{l}1.16 \mathrm{E}-10 \\
1.88 \mathrm{E}-19 \\
2.67 \mathrm{E}-16 \\
1.35 \mathrm{E}-18 \\
2.46 \mathrm{E}-14 \\
1.03 \mathrm{E}-18 \\
2.84 \mathrm{E}-08 \\
6.06 \mathrm{E}-07 \\
1.70 \mathrm{E}-07 \\
1.78 \mathrm{E}-06 \\
2.46 \mathrm{E}-14 \\
2.67 \mathrm{E}-16 \\
1.03 \mathrm{E}-18 \\
3.06 \mathrm{E}-09 \\
3.08 \mathrm{E}-08 \\
3.08 \mathrm{E}-08 \\
1.18 \mathrm{E}-09 \\
3.09 \mathrm{E}-05 \\
3.08 \mathrm{E}-08 \\
2.85 \mathrm{E}-03 \\
3.96 \mathrm{E}-08 \\
2.43 \mathrm{E}-14 \\
2.67 \mathrm{E}-16 \\
2.90 \mathrm{E}-16 \\
9.14 \mathrm{E}-11 \\
0.00 \mathrm{E}+00 \\
2.00 \mathrm{E}-09 \\
2.46 \mathrm{E}-14 \\
1.44 \mathrm{E}-13 \\
2.54 \mathrm{E}-12 \\
9.14 \mathrm{E}-11 \\
2.00 \mathrm{E}-09 \\
2.85 \mathrm{E}-03 \\
2.70 \mathrm{E}-07\end{array}$ \\
\hline
\end{tabular}

(a) Based on data supplied by Westinghouse Hanford Company. 
TABLE A.2. TRAC Radionuclide Inventory for Tank Farm Group B

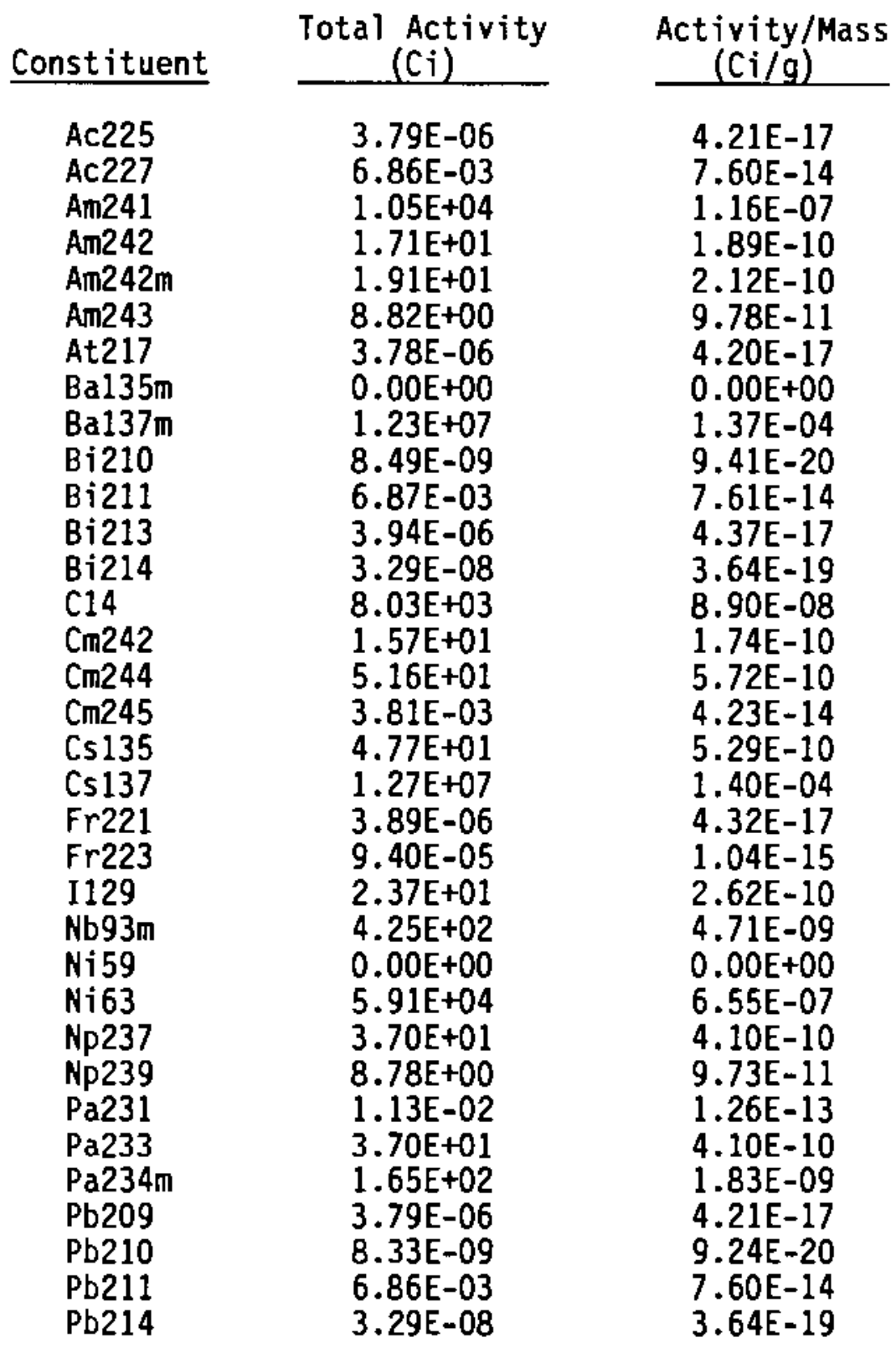


TABLE A.2. (contd)

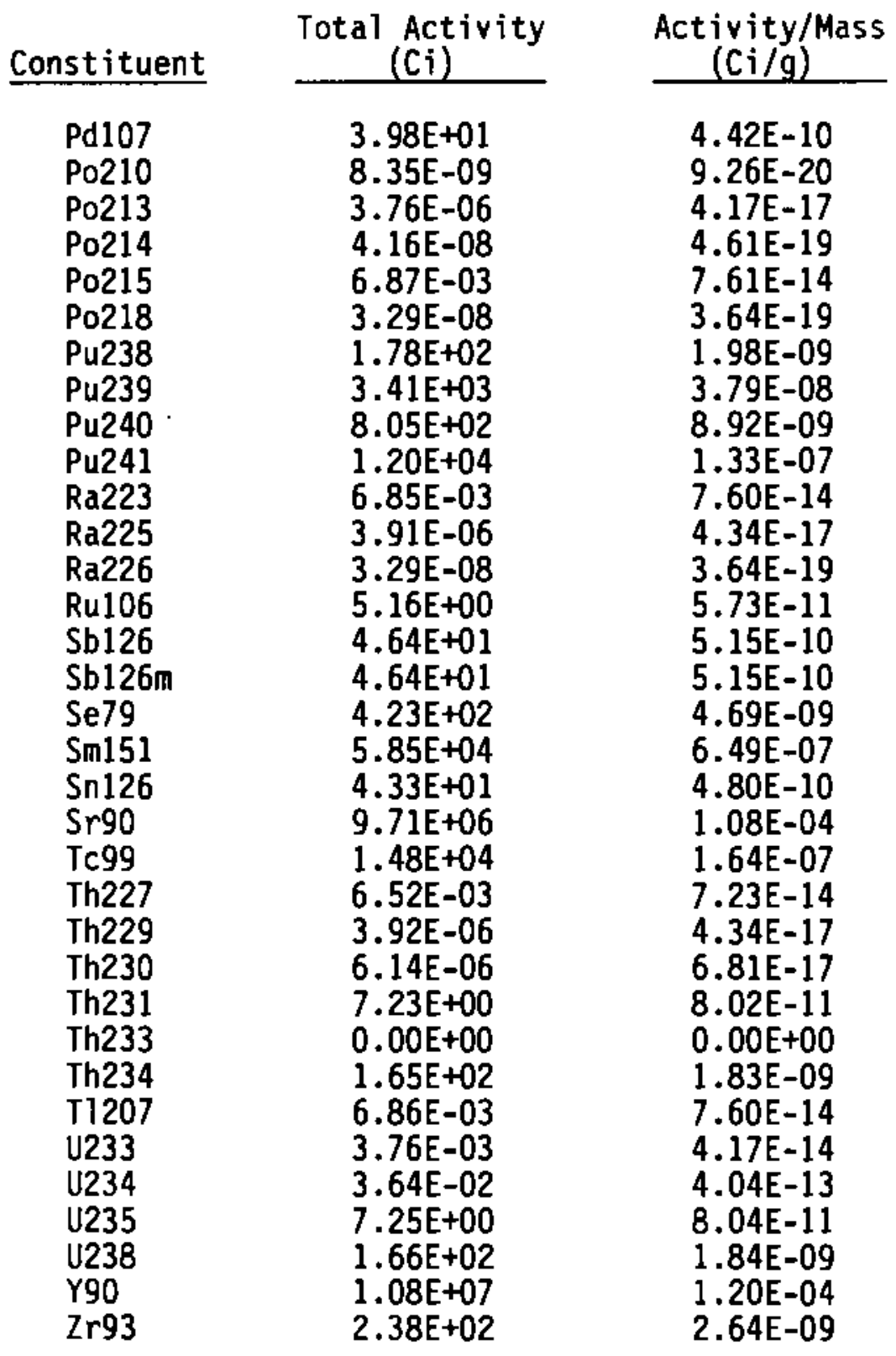


TABLE A.3. TRAC Radionuclide Inventory for Tank Farm Group C

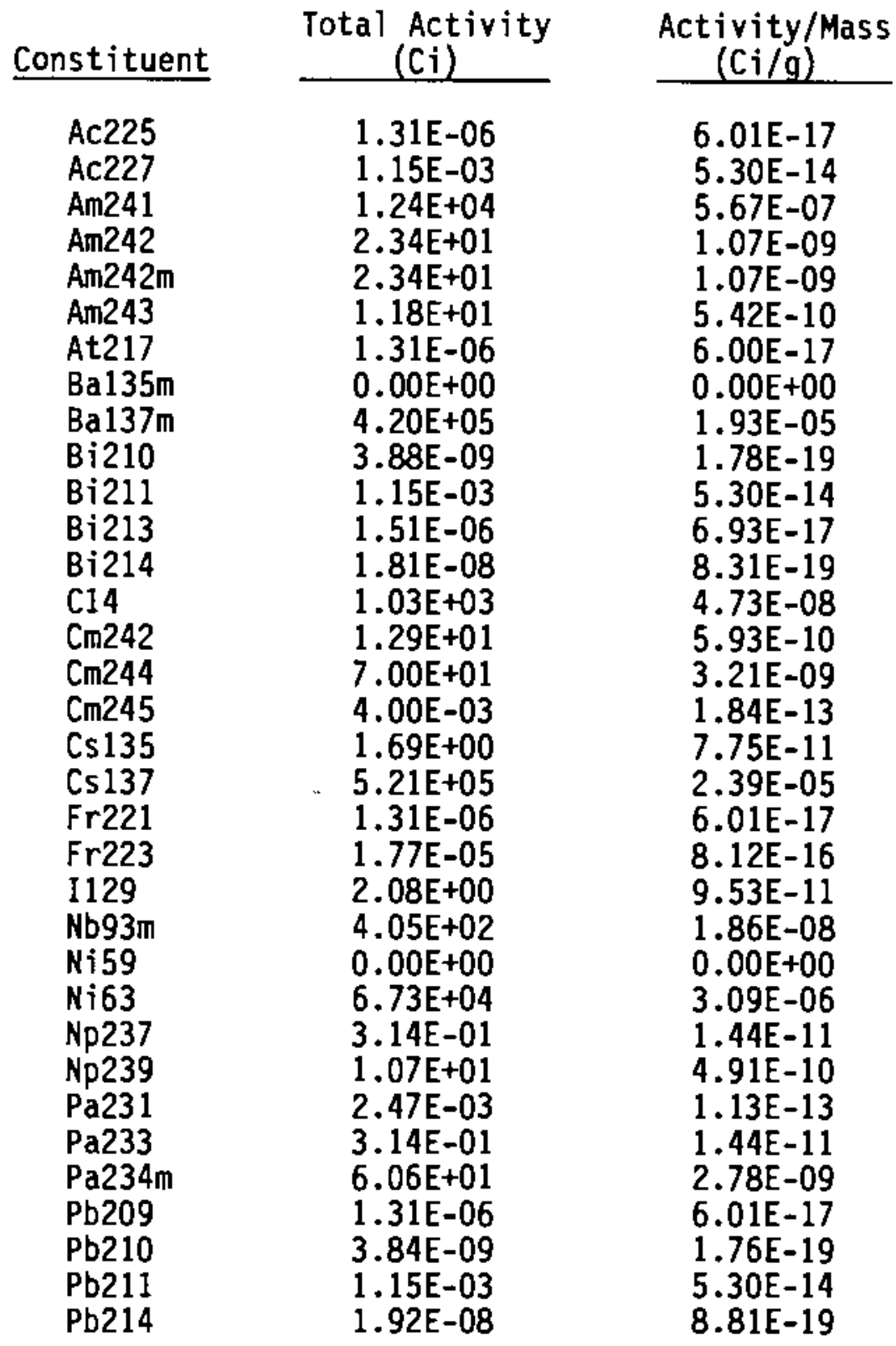


TABLE A.3. (contd)

Const ituent

Pd107

Po210

Po213

Po214

Po215

Po218

Pu238

Pu239

Pu240

Pu241

Ra223

Ra225

Ra226

Ru106

Sb126

Sb126m

Se79

Sm151

Sn126

Sr90

Tc99

Th227

Th229

Th230

Th231

Th233

Th234

T1207

U233

U234

U235

U238

Y90

Zr93
Total Activity (Ci)

$4.12 \mathrm{E}+00$

3. $64 \mathrm{E}-09$

1.31E-06

2. $40 \mathrm{E}-08$

$1.15 \mathrm{E}-03$

1.92E-08

1. $94 \mathrm{E}+02$

$5.12 \mathrm{E}+03$

$1.34 \mathrm{E}+03$

$1.66 \mathrm{E}+04$

1. 15E-03

$1.41 \mathrm{E}-06$

1. $92 \mathrm{E}-08$

$5.95 \mathrm{E}+00$

$9.08 \mathrm{E}+01$

$9.08 \mathrm{E}+01$

$3.12 \mathrm{E}+01$

$1.05 E+05$

$9.08 \mathrm{E}+01$

$5.62 E+06$

$1.05 \mathrm{E}+03$

1.14E-03

1.31E-06

3. 36E-06

$2.35 \mathrm{E}+00$

$0.00 \mathrm{E}+00$

$6.06 \mathrm{E}+01$

1.15E-03

6.61E-04

2. $48 \mathrm{E}-02$

$2.35 E+00$

$6.06 \mathrm{E}+01$

$5.62 \mathrm{E}+06$

$5.62 \mathrm{E}+02$
Activity/Mass

( $\mathrm{Ci} / \mathrm{g})$

1. $89 \mathrm{E}-10$

$1.67 \mathrm{E}-19$

$6.00 \mathrm{E}-17$

1. $10 \mathrm{E}-18$

5.30E-14

8.81E-19

8. $90 \mathrm{E}-09$

2.35E-07

$6.15 \mathrm{E}-08$

7.61E-07

5.30E-14

$6.47 \mathrm{E}-17$

8.81E-19

2.73E-10

4.16E-09

4.16E-09

1. $43 \mathrm{E}-09$

4.81E-06

4.16E-09

2. $58 \mathrm{E}-04$

4.84E-08

5. $25 \mathrm{E}-14$

6.01E-17

1. $54 \mathrm{E}-16$

1. $08 \mathrm{E}-10$

$0.00 \mathrm{E}+00$

2.78E-09

5.30E-14

3.03E-14

$1.14 \mathrm{E}-12$

1.08E-10

2.78E-09

2. $58 \mathrm{E}-04$

$2.58 \mathrm{E}-08$ 
IABLE A.4. TRAC Radionuclide Inventory for Tank Farm Group $S$

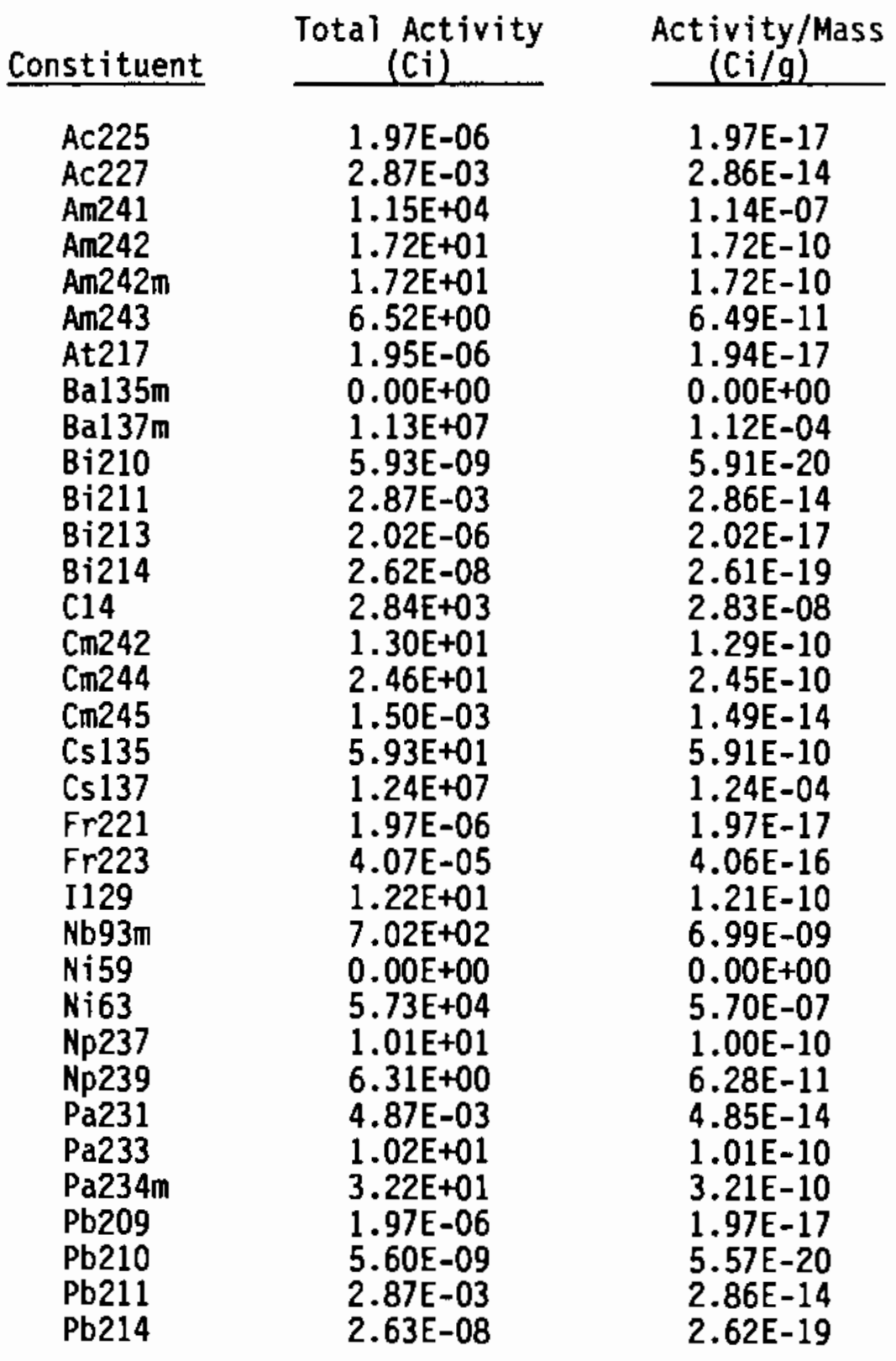


TABLE A.4. (contd)

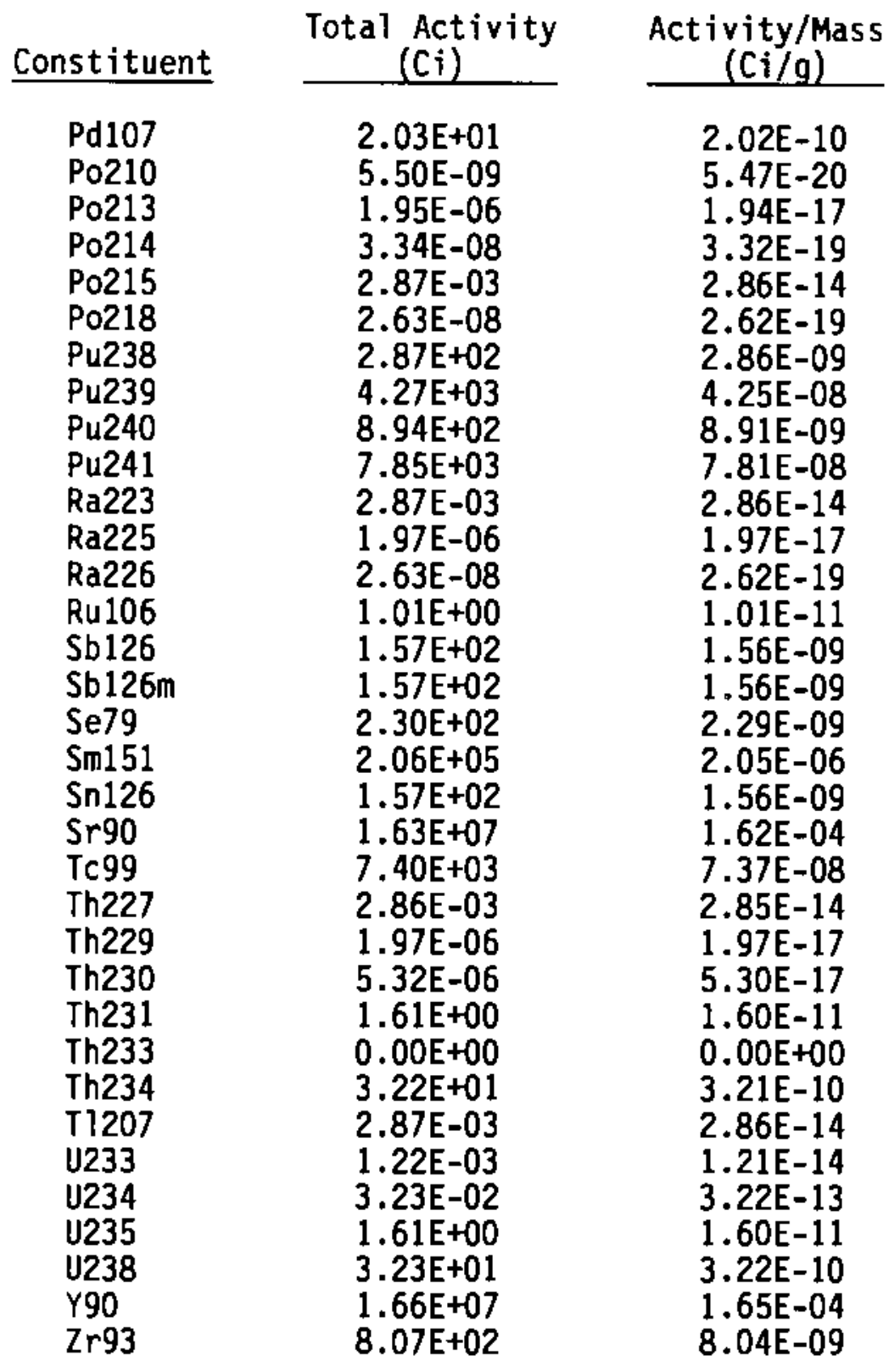


TABLE A.5. TRAC Radionuclide Inventory for Tank Farm Group T

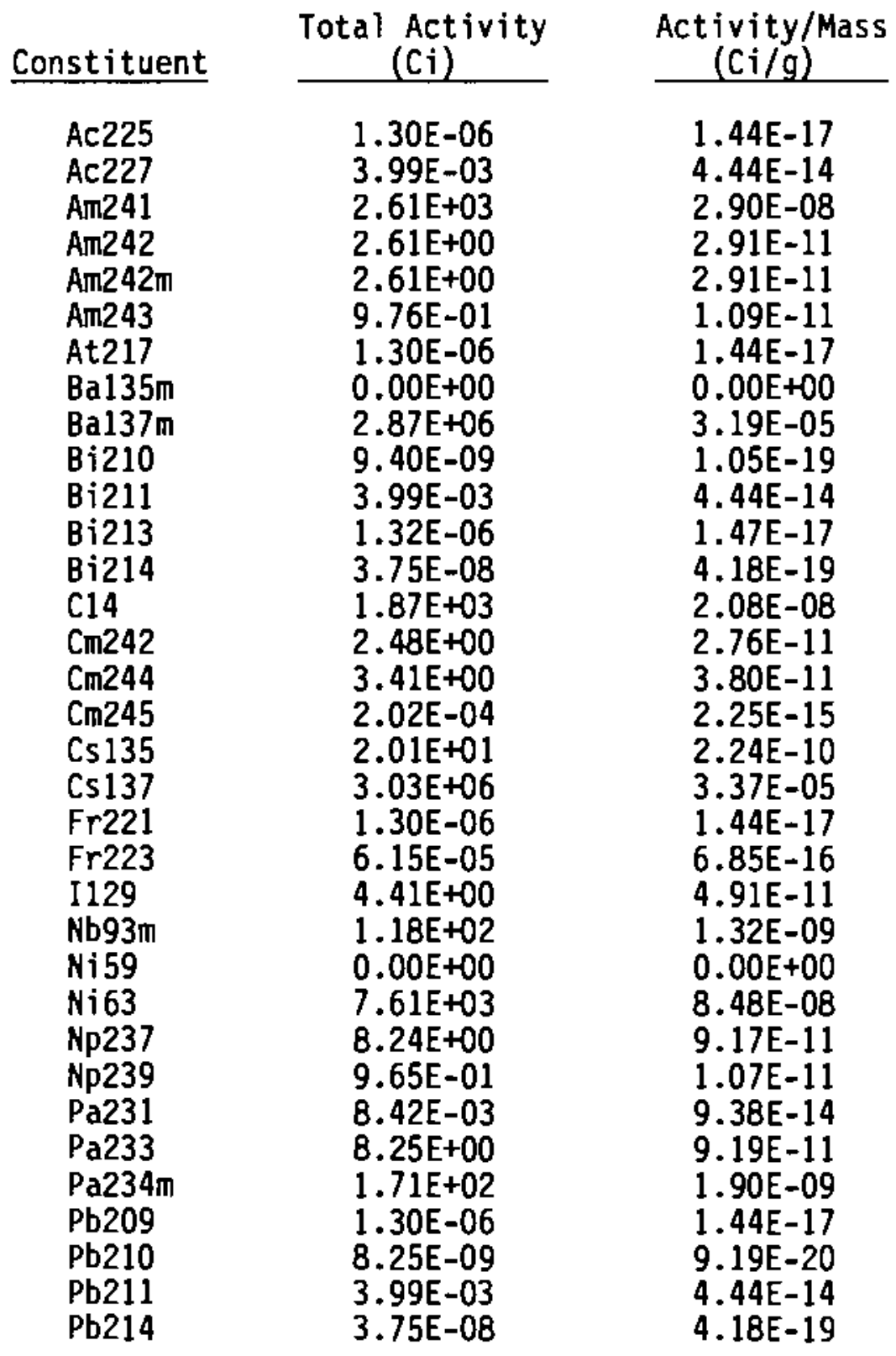


TABLE A.5. (contd)

\begin{tabular}{|c|c|c|}
\hline Constituent & $\begin{array}{c}\text { Total Activity } \\
\text { (Ci) }\end{array}$ & $\begin{array}{c}\text { Activity/Mass } \\
(\mathrm{Ci} / \mathrm{g}) \\
\end{array}$ \\
\hline $\begin{array}{l}\text { Pd107 } \\
\text { Po210 } \\
\text { Po213 } \\
\text { Po214 } \\
\text { Po215 } \\
\text { Po218 } \\
\text { Pu238 } \\
\text { Pu239 } \\
\text { Pu240 } \\
\text { Pu241 } \\
\text { Ra223 } \\
\text { Ra225 } \\
\text { Ra226 } \\
\text { Ru106 } \\
\text { Sb126 } \\
\text { Sb126m } \\
\text { Se79 } \\
\text { Sm151 } \\
\text { Sn126 } \\
\text { Sr90 } \\
\text { Tc99 } \\
\text { Th227 } \\
\text { Th229 } \\
\text { Th230 } \\
\text { Th231 } \\
\text { Th233 } \\
\text { Th234 } \\
\text { T1207 } \\
\text { U233 } \\
\text { U234 } \\
\text { U235 } \\
\text { U238 } \\
\text { Y90 } \\
\text { Zr93 }\end{array}$ & $\begin{array}{l}8.53 \mathrm{E}+00 \\
8.16 \mathrm{E}-09 \\
1.30 \mathrm{E}-06 \\
4.12 \mathrm{E}-08 \\
3.99 \mathrm{E}-03 \\
3.75 \mathrm{E}-08 \\
1.94 \mathrm{E}+02 \\
2.64 \mathrm{E}+03 \\
4.71 \mathrm{E}+02 \\
5.35 \mathrm{E}+03 \\
3.99 \mathrm{E}-03 \\
1.30 \mathrm{E}-06 \\
3.75 \mathrm{E}-08 \\
3.72 \mathrm{E}-03 \\
5.67 \mathrm{E}+01 \\
5.67 \mathrm{E}+01 \\
9.65 \mathrm{E}+01 \\
6.39 \mathrm{E}+04 \\
5.67 \mathrm{E}+01 \\
1.74 \mathrm{E}+06 \\
3.38 \mathrm{E}+03 \\
3.75 \mathrm{E}-03 \\
1.30 \mathrm{E}-06 \\
7.11 \mathrm{E}-06 \\
6.85 \mathrm{E}+00 \\
0.00 \mathrm{E}+00 \\
1.71 \mathrm{E}+02 \\
3.99 \mathrm{E}-03 \\
9.66 \mathrm{E}-04 \\
3.79 \mathrm{E}-02 \\
6.85 \mathrm{E}+00 \\
1.71 \mathrm{E}+02 \\
1.86 \mathrm{E}+06 \\
4.35 \mathrm{E}+01\end{array}$ & $\begin{array}{l}9.49 \mathrm{E}-11 \\
9.09 \mathrm{E}-20 \\
1.44 \mathrm{E}-17 \\
4.59 \mathrm{E}-19 \\
4.44 \mathrm{E}-14 \\
4.18 \mathrm{E}-19 \\
2.16 \mathrm{E}-09 \\
2.93 \mathrm{E}-08 \\
5.24 \mathrm{E}-09 \\
5.96 \mathrm{E}-08 \\
4.44 \mathrm{E}-14 \\
1.44 \mathrm{E}-17 \\
4.18 \mathrm{E}-19 \\
4.14 \mathrm{E}-14 \\
6.31 \mathrm{E}-10 \\
6.31 \mathrm{E}-10 \\
1.07 \mathrm{E}-09 \\
7.12 \mathrm{E}-07 \\
6.31 \mathrm{E}-10 \\
1.93 \mathrm{E}-05 \\
3.77 \mathrm{E}-08 \\
4.17 \mathrm{E}-14 \\
1.44 \mathrm{E}-17 \\
7.92 \mathrm{E}-17 \\
7.62 \mathrm{E}-11 \\
0.00 \mathrm{E}+00 \\
1.90 \mathrm{E}-09 \\
4.44 \mathrm{E}-14 \\
1.08 \mathrm{E}-14 \\
4.22 \mathrm{E}-13 \\
7.62 \mathrm{E}-11 \\
1.90 \mathrm{E}-09 \\
2.07 \mathrm{E}-05 \\
4.84 \mathrm{E}-10\end{array}$ \\
\hline
\end{tabular}


IABLE A.6. TRAC Radionuclide Inventory for Tank Farm Group U

\begin{tabular}{|c|c|c|}
\hline Constituent & $\begin{array}{c}\text { Total Activity } \\
\text { (Ci) }\end{array}$ & $\begin{array}{l}\text { Activity/Mass } \\
(\mathrm{Ci} / \mathrm{g})\end{array}$ \\
\hline $\begin{array}{l}\text { Ac225 } \\
\text { Ac227 } \\
\text { Am241 } \\
\text { Am242 } \\
\text { Am242m } \\
\text { C14 } \\
\text { Cm242 } \\
\text { Cm244 } \\
\text { Cm245 } \\
\text { Cs135 } \\
\text { Cs137 } \\
\text { I129 } \\
\text { Nb93m } \\
\text { Ni63 } \\
\text { Np237 } \\
\text { Pa231 } \\
\text { Pa233 } \\
\text { Pb210 } \\
\text { Po210 } \\
\text { Pu238 } \\
\text { Pu239 } \\
\text { Pu240 } \\
\text { Pu241 } \\
\text { Ra223 } \\
\text { Ra225 } \\
\text { Ra226 } \\
\text { Ru106 } \\
\text { Se79 } \\
\text { Sm151 } \\
\text { Sn126 } \\
\text { Sr90 } \\
\text { Tc99 } \\
\text { Th229 } \\
\text { Th230 } \\
\text { Th234 } \\
\text { U233 } \\
\text { U234 } \\
\text { U235 } \\
\text { U238 } \\
\text { Y90 }\end{array}$ & $\begin{array}{l}2.86 \mathrm{E}-07 \\
4.26 \mathrm{E}-04 \\
3.68 \mathrm{E}+02 \\
3.53 \mathrm{E}-01 \\
3.54 \mathrm{E}-01 \\
8.19 \mathrm{E}+01 \\
3.28 \mathrm{E}-01 \\
4.07 \mathrm{E}-01 \\
2.55 \mathrm{E}-05 \\
3.34 \mathrm{E}+00 \\
5.45 \mathrm{E}+05 \\
3.25 \mathrm{E}-01 \\
1.81 \mathrm{E}+01 \\
7.93 \mathrm{E}+02 \\
7.07 \mathrm{E}-01 \\
1.05 \mathrm{E}-03 \\
7.07 \mathrm{E}-01 \\
1.08 \mathrm{E}-09 \\
1.08 \mathrm{E}-09 \\
4.09 \mathrm{E}+01 \\
2.14 \mathrm{E}+02 \\
4.40 \mathrm{E}+01 \\
3.46 \mathrm{E}+02 \\
4.26 \mathrm{E}-04 \\
2.86 \mathrm{E}-07 \\
6.42 \mathrm{E}-09 \\
1.16 \mathrm{E}-03 \\
6.64 \mathrm{E}+00 \\
1.01 \mathrm{E}+04 \\
7.74 \mathrm{E}+00 \\
5.35 \mathrm{E}+05 \\
2.31 \mathrm{E}+02 \\
2.86 \mathrm{E}-07 \\
1.07 \mathrm{E}-06 \\
3.33 \mathrm{E}+01 \\
1.53 \mathrm{E}-04 \\
7.48 \mathrm{E}-03 \\
1.16 \mathrm{E}+00 \\
3.33 \mathrm{E}+01 \\
5.35 \mathrm{E}+05\end{array}$ & $\begin{array}{l}1.21 \mathrm{E}-17 \\
1.80 \mathrm{E}-14 \\
1.56 \mathrm{E}-08 \\
1.50 \mathrm{E}-11 \\
1.50 \mathrm{E}-11 \\
3.47 \mathrm{E}-09 \\
1.39 \mathrm{E}-11 \\
1.72 \mathrm{E}-11 \\
1.08 \mathrm{E}-15 \\
1.41 \mathrm{E}-10 \\
2.31 \mathrm{E}-05 \\
1.38 \mathrm{E}-11 \\
7.67 \mathrm{E}-10 \\
3.36 \mathrm{E}-08 \\
3.00 \mathrm{E}-11 \\
4.46 \mathrm{E}-14 \\
3.00 \mathrm{E}-11 \\
4.59 \mathrm{E}-20 \\
4.59 \mathrm{E}-20 \\
1.73 \mathrm{E}-09 \\
9.09 \mathrm{E}-09 \\
1.86 \mathrm{E}-09 \\
1.47 \mathrm{E}-08 \\
1.80 \mathrm{E}-14 \\
1.21 \mathrm{E}-17 \\
2.72 \mathrm{E}-19 \\
4.91 \mathrm{E}-14 \\
2.81 \mathrm{E}-10 \\
4.26 \mathrm{E}-07 \\
3.28 \mathrm{E}-10 \\
2.27 \mathrm{E}-05 \\
9.80 \mathrm{E}-09 \\
1.21 \mathrm{E}-17 \\
4.54 \mathrm{E}-17 \\
1.41 \mathrm{E}-09 \\
6.50 \mathrm{E}-15 \\
3.17 \mathrm{E}-13 \\
4.93 \mathrm{E}-11 \\
1.41 \mathrm{E}-09 \\
2.27 \mathrm{E}-05\end{array}$ \\
\hline
\end{tabular}


TABLE A.7. Radionuclides Not Modeled(a)

\begin{tabular}{|c|c|c|c|}
\hline Radionuclide & Rationale & Radionuclide & Rationale \\
\hline $\begin{array}{l}217 \mathrm{At} \\
135 \mathrm{Ba} \\
210 \mathrm{Bi} \\
211 \mathrm{Bi} \\
213 \mathrm{Bi} \\
214 \mathrm{Bi} \\
221 \mathrm{Fr} \\
223 \mathrm{Fr} \\
59 \mathrm{Ni} \\
239 \mathrm{~Np} \\
231 \mathrm{Th} \\
207 \mathrm{Tl}\end{array}$ & $\begin{array}{l}\text { (b) } \\
\text { (b) (c) } \\
\text { (b) (c) } \\
\text { (b) } \\
\text { (b) } \\
\text { (b) } \\
\text { (b) } \\
\text { (b) } \\
\text { (b) } \\
\text { (b) (c) } \\
\text { (b) } \\
\text { (b) }\end{array}$ & $\begin{array}{l}234 \mathrm{pa} \\
209 \mathrm{pb} \\
211 \mathrm{~Pb} \\
214 \mathrm{pb} \\
213 \mathrm{Po} \\
214 \mathrm{Po} \\
215 \mathrm{Po} \\
218 \mathrm{Po} \\
126 \mathrm{Sb} \\
227 \mathrm{Th} \\
233 \mathrm{Th}\end{array}$ & $\begin{array}{l}\text { (b) } \\
\text { (b) (c) } \\
\text { (b) } \\
\text { (b) } \\
\text { (b) } \\
\text { (b) } \\
\text { (b) } \\
\text { (b) } \\
\text { (b) } \\
\text { (b) (c) } \\
\text { (b) }\end{array}$ \\
\hline
\end{tabular}

(a) of the radionuclides listed in the preceding tables in this appendix, a number were not modeled because of their properties. This table lists the radionuclides not modeled and the rationale.

(b) Radionuclide has too short of a half-life for concern as parent.

(c) Radionuclide is also in a decay chain such that the contribution from this decay product will normally be small compared to the exposure from the parent. 


\section{APPENDIX B}

IRAC CHEMICAL SINGLE-SHELL TANK FARM INVENTORIES 
APPENDIX B

TRAC CHEMICAL SINGLE-SHELL TANK FARM INVENTORIES

TABLE B.1. Tank Farm A Chemical Inventories from TRAC Output(a)

\begin{tabular}{|c|c|c|}
\hline $\begin{array}{l}\text { Chemical } \\
\text { Name } \\
\end{array}$ & $\begin{array}{l}\text { Total Mass } \\
\begin{array}{l}(\mathrm{g}) \\
\end{array}\end{array}$ & $\begin{array}{c}\text { Concentration } \\
(g / g)\end{array}$ \\
\hline $\begin{array}{l}\mathrm{Ag} \\
\mathrm{AI} \\
\mathrm{Ba} \\
\mathrm{Bi} \\
\mathrm{C}_{2} \mathrm{H}_{3} \mathrm{O}_{3} \\
\mathrm{C}_{6} \mathrm{H}_{5} \\
\mathrm{CO}_{3} \\
\mathrm{C}_{2} \mathrm{O}_{4} \\
\mathrm{Ca} \\
\mathrm{Cd} \\
\mathrm{Ce} \\
\mathrm{Cl} \\
\mathrm{Cr} \\
\mathrm{EDTA} \\
\mathrm{F} \\
\mathrm{Fe} \\
\mathrm{Fe}\left(\mathrm{CN}_{6} 6\right. \\
\mathrm{HEDTA} \\
\mathrm{Hg} \\
\mathrm{K} \\
\mathrm{La} \\
\mathrm{Mn} \\
\mathrm{NO} 2 \\
\mathrm{NO} 3 \\
\mathrm{Na} \\
\mathrm{Ni} \\
\mathrm{OH}_{3} \\
\mathrm{PO} 4 \\
\mathrm{~Pb} \\
\mathrm{SeO}_{4} \\
\mathrm{SiO}_{3} \\
\mathrm{Sn}^{\mathrm{SO}} 4 \\
\mathrm{Sr}_{4} \\
\mathrm{HO} 4 \\
\mathrm{ZrO} \\
\end{array}$ & $\begin{array}{l}3.60 \mathrm{E}-03 \\
7.20 \mathrm{E}+07 \\
1.90 \mathrm{E}+05 \\
1.10 \mathrm{E}-08 \\
3.10 \mathrm{E}+06 \\
2.70 \mathrm{E}+07 \\
9.40 \mathrm{E}+07 \\
0.00 \mathrm{E}+00 \\
2.50 \mathrm{E}+05 \\
0.00 \mathrm{E}+00 \\
9.50 \mathrm{E}+03 \\
8.10 \mathrm{E}-04 \\
6.70 \mathrm{E}+06 \\
1.80 \mathrm{E}+07 \\
3.40 \mathrm{E}+05 \\
2.30 \mathrm{E}+08 \\
8.70 \mathrm{E}+02 \\
2.90 \mathrm{E}+07 \\
0.00 \mathrm{E}+00 \\
4.40 \mathrm{E}+05 \\
0.00 \mathrm{E}+00 \\
3.10 \mathrm{E}+06 \\
1.70 \mathrm{E}+07 \\
4.10 \mathrm{E}+09 \\
1.50 \mathrm{E}+09 \\
4.10 \mathrm{E}+05 \\
2.70 \mathrm{E}+08 \\
8.60 \mathrm{E}+05 \\
1.00 \mathrm{E}+05 \\
0.00 \mathrm{E}+00 \\
1.20 \mathrm{E}+06 \\
0.00 \mathrm{E}+00 \\
1.30 \mathrm{E}+08 \\
2.60 \mathrm{E}+04 \\
0.00 \mathrm{E}+00 \\
2.30 \mathrm{E}+05\end{array}$ & $\begin{array}{l}1.60 \mathrm{E}-13 \\
3.30 \mathrm{E}-03 \\
8.70 \mathrm{E}-06 \\
5.10 \mathrm{E}-19 \\
1.40 \mathrm{E}-04 \\
1.20 \mathrm{E}-03 \\
4.30 \mathrm{E}-03 \\
0.00 \mathrm{E}+00 \\
1.10 \mathrm{E}-05 \\
0.00 \mathrm{E}+00 \\
4.40 \mathrm{E}-07 \\
3.70 \mathrm{E}-14 \\
3.10 \mathrm{E}-04 \\
8.40 \mathrm{E}-04 \\
1.50 \mathrm{E}-05 \\
1.00 \mathrm{E}-02 \\
4.00 \mathrm{E}-08 \\
1.30 \mathrm{E}-03 \\
0.00 \mathrm{E}+00 \\
2.00 \mathrm{E}-05 \\
0.00 \mathrm{E}+00 \\
1.40 \mathrm{E}-04 \\
7.70 \mathrm{E}-04 \\
1.90 \mathrm{E}-01 \\
6.80 \mathrm{E}-02 \\
1.90 \mathrm{E}-05 \\
1.20 \mathrm{E}-02 \\
4.00 \mathrm{E}-05 \\
4.80 \mathrm{E}-06 \\
0.00 \mathrm{E}+00 \\
5.50 \mathrm{E}-05 \\
0.00 \mathrm{E}+00 \\
5.80 \mathrm{E}-03 \\
1.20 \mathrm{E}-06 \\
0.00 \mathrm{E}+00 \\
1.00 \mathrm{E}-05\end{array}$ \\
\hline
\end{tabular}

(a) Based on data supplied by Westinghouse Hanford Company. 
TABLE B.2. Tank Farm B Chemical Inventories from TRAC Output

\begin{tabular}{|c|c|c|}
\hline $\begin{array}{c}\text { Chemical } \\
\text { Name } \\
\end{array}$ & $\begin{array}{l}\text { Total Mass } \\
(g) \\
\end{array}$ & $\begin{array}{c}\text { Concentratior } \\
(\mathrm{g} / \mathrm{g})\end{array}$ \\
\hline 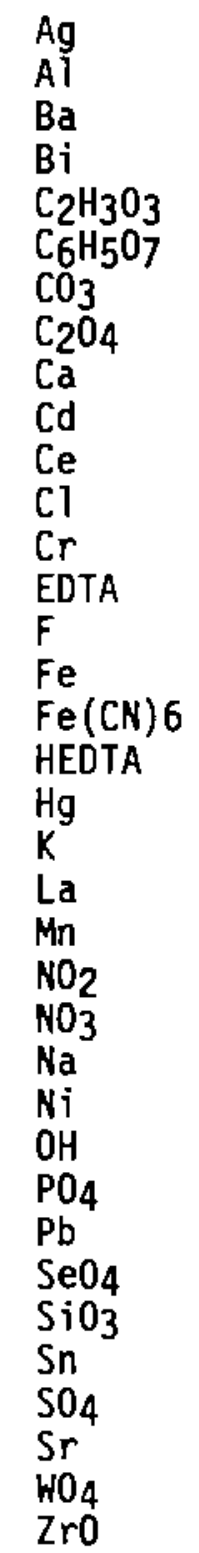 & $\begin{array}{l}2.50 \mathrm{E}-01 \\
2.20 \mathrm{E}+09 \\
1.40 \mathrm{E}+05 \\
4.50 \mathrm{E}+09 \\
3.30 \mathrm{E}+05 \\
1.40 \mathrm{E}+09 \\
1.60 \mathrm{E}+09 \\
0.00 \mathrm{E}+00 \\
8.90 \mathrm{E}+06 \\
0.00 \mathrm{E}+00 \\
2.60 \mathrm{E}+05 \\
1.50 \mathrm{E}-01 \\
6.30 \mathrm{E}+06 \\
1.90 \mathrm{E}+06 \\
2.50 \mathrm{E}+08 \\
1.80 \mathrm{E}+08 \\
3.90 \mathrm{E}+06 \\
3.30 \mathrm{E}+06 \\
0.00 \mathrm{E}+00 \\
3.00 \mathrm{E}+07 \\
4.60 \mathrm{E}+05 \\
1.80 \mathrm{E}+06 \\
2.30 \mathrm{E}+09 \\
4.00 \mathrm{E}+10 \\
1.50 \mathrm{E}+10 \\
3.90 \mathrm{E}+07 \\
1.60 \mathrm{E}+09 \\
3.20 \mathrm{E}+09 \\
1.90 \mathrm{E}+07 \\
0.00 \mathrm{E}+00 \\
2.70 \mathrm{E}+08 \\
0.00 \mathrm{E}+00 \\
7.30 \mathrm{E}+08 \\
1.40 \mathrm{E}+07 \\
0.00 \mathrm{E}+00 \\
9.90 \mathrm{E}+06\end{array}$ & $\begin{array}{l}1.07 \mathrm{E}-12 \\
1.72 \mathrm{E}-02 \\
4.19 \mathrm{E}-06 \\
4.21 \mathrm{E}-02 \\
2.47 \mathrm{E}-06 \\
4.84 \mathrm{E}-02 \\
2.29 \mathrm{E}-02 \\
0.00 \mathrm{E}+00 \\
1.90 \mathrm{E}-05 \\
0.00 \mathrm{E}+00 \\
1.24 \mathrm{E}-06 \\
7.16 \mathrm{E}-12 \\
1.03 \mathrm{E}-05 \\
1.18 \mathrm{E}-05 \\
1.63 \mathrm{E}-03 \\
8.27 \mathrm{E}-03 \\
2.52 \mathrm{E}-05 \\
9.30 \mathrm{E}-05 \\
0.00 \mathrm{E}+00 \\
5.60 \mathrm{E}-04 \\
5.13 \mathrm{E}-06 \\
8.31 \mathrm{E}-05 \\
7.72 \mathrm{E}-02 \\
7.40 \mathrm{E}-01 \\
2.91 \mathrm{E}-01 \\
1.02 \mathrm{E}-04 \\
5.08 \mathrm{E}-02 \\
1.62 \mathrm{E}-02 \\
7.80 \mathrm{E}-04 \\
0.00 \mathrm{E}+00 \\
1.08 \mathrm{E}-03 \\
0.00 \mathrm{E}+00 \\
1.90 \mathrm{E}-03 \\
6.70 \mathrm{E}-04 \\
0.00 \mathrm{E}+00 \\
7.96 \mathrm{E}-04\end{array}$ \\
\hline
\end{tabular}


TABLE B.3. Tank Farm C Chemical Inventories from TRAC Output

\begin{tabular}{|c|c|c|}
\hline $\begin{array}{l}\text { Chemical } \\
\text { Name } \\
\end{array}$ & $\begin{array}{l}\text { Total Mass } \\
(\mathrm{g})\end{array}$ & $\begin{array}{c}\text { Concentration } \\
(\mathrm{g} / \mathrm{g})\end{array}$ \\
\hline 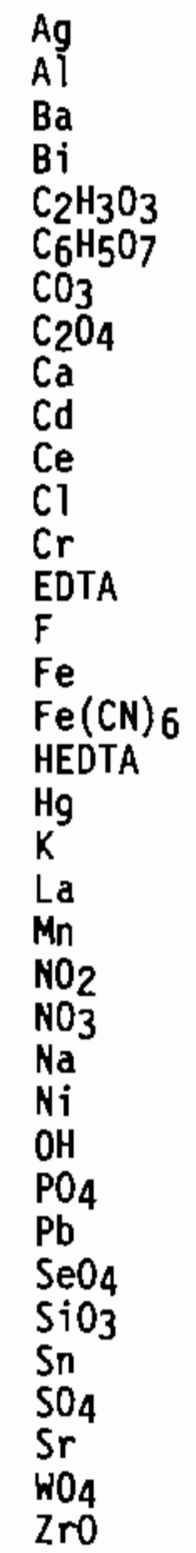 & $\begin{array}{l}1.16 \mathrm{E}-02 \\
9.14 \mathrm{E}+08 \\
8.66 \mathrm{E}+04 \\
3.32 \mathrm{E}+07 \\
1.20 \mathrm{E}+05 \\
1.13 \mathrm{E}+08 \\
9.24 \mathrm{E}+07 \\
0.00 \mathrm{E}+00 \\
1.05 \mathrm{E}+07 \\
0.00 \mathrm{E}+00 \\
1.35 \mathrm{E}+03 \\
5.08 \mathrm{E}-04 \\
1.42 \mathrm{E}+06 \\
3.95 \mathrm{E}+05 \\
2.47 \mathrm{E}+08 \\
6.96 \mathrm{E}+07 \\
2.10 \mathrm{E}+07 \\
9.00 \mathrm{E}+05 \\
0.00 \mathrm{E}+00 \\
1.97 \mathrm{E}+05 \\
0.00 \mathrm{E}+00 \\
6.55 \mathrm{E}+06 \\
9.70 \mathrm{E}+06 \\
5.81 \mathrm{E}+09 \\
2.71 \mathrm{E}+09 \\
1.53 \mathrm{E}+07 \\
2.03 \mathrm{E}+09 \\
2.46 \mathrm{E}+07 \\
4.17 \mathrm{E}+06 \\
0.00 \mathrm{E}+00 \\
4.75 \mathrm{E}+05 \\
0.00 \mathrm{E}+00 \\
9.90 \mathrm{E}+07 \\
9.81 \mathrm{E}+03 \\
0.00 \mathrm{E}+00 \\
3.59 \mathrm{E}+08\end{array}$ & $\begin{array}{l}5.33 \mathrm{E}-13 \\
4.19 \mathrm{E}-02 \\
3.97 \mathrm{E}-06 \\
1.52 \mathrm{E}-03 \\
5.50 \mathrm{E}-06 \\
5.20 \mathrm{E}-03 \\
4.24 \mathrm{E}-03 \\
0.00 \mathrm{E}+00 \\
4.80 \mathrm{E}-04 \\
0.00 \mathrm{E}+00 \\
6.18 \mathrm{E}-08 \\
2.33 \mathrm{E}-14 \\
6.52 \mathrm{E}-05 \\
1.81 \mathrm{E}-05 \\
1.13 \mathrm{E}-02 \\
3.19 \mathrm{E}-03 \\
9.64 \mathrm{E}-04 \\
4.13 \mathrm{E}-05 \\
0.00 \mathrm{E}+00 \\
9.03 \mathrm{E}-06 \\
0.00 \mathrm{E}+00 \\
3.01 \mathrm{E}-04 \\
4.45 \mathrm{E}-04 \\
2.67 \mathrm{E}-01 \\
1.24 \mathrm{E}-01 \\
7.00 \mathrm{E}-04 \\
9.32 \mathrm{E}-02 \\
1.13 \mathrm{E}-03 \\
1.91 \mathrm{E}-04 \\
0.00 \mathrm{E}+00 \\
2.18 \mathrm{E}-05 \\
0.00 \mathrm{E}+00 \\
4.54 \mathrm{E}-03 \\
4.50 \mathrm{E}-07 \\
0.00 \mathrm{E}+00 \\
1.65 \mathrm{E}-02\end{array}$ \\
\hline
\end{tabular}


TABLE B.4. Tank Farm S Chemical Inventories from TRAC Output

\begin{tabular}{|c|c|c|}
\hline $\begin{array}{c}\text { Chemical } \\
\text { Name } \\
\end{array}$ & $\begin{array}{c}\text { Total Mass } \\
(\mathrm{g})\end{array}$ & $\begin{array}{c}\text { Concentratio } \\
(g / g)\end{array}$ \\
\hline $\mathrm{Ag}$ & $9.53 \mathrm{E}-02$ & $9.49 E-13$ \\
\hline Al & $2.79 \mathrm{E}+09$ & $2.78 \mathrm{E}-02$ \\
\hline $\mathrm{Ba}$ & $1.83 \mathrm{E}+05$ & $1.82 E-06$ \\
\hline & $9.04 \mathrm{E}-09$ & $9.01 \mathrm{E}-20$ \\
\hline $\mathrm{C}_{2} \mathrm{H}_{3} \mathrm{O}_{3}$ & $2.03 E+06$ & $2.02 \mathrm{E}-05$ \\
\hline $\mathrm{C}_{6} \mathrm{H}_{507}$ & $5.43 E+08$ & $5.41 E-03$ \\
\hline $\begin{array}{l}\mathrm{CO}_{3} \\
\mathrm{C}_{2} \mathrm{O}_{4}\end{array}$ & $\begin{array}{l}4.01 \mathrm{E}+08 \\
0.00 \mathrm{E}+00\end{array}$ & $\begin{array}{l}4.00 \mathrm{E}-03 \\
0.00 \mathrm{E}+00\end{array}$ \\
\hline $\mathrm{Ca}$ & $8.83 \mathrm{E}+05$ & $8.80 E-06$ \\
\hline Cd & $0.00 \mathrm{E}+00$ & $0.00 \mathrm{E}+00$ \\
\hline $\mathrm{Ce}$ & $9.64 \mathrm{E}+04$ & $9.60 \mathrm{E}-07$ \\
\hline $\mathrm{Cl}$ & $5.35 \mathrm{E}-02$ & 5. $33 \mathrm{E}-13$ \\
\hline $\mathrm{Cr}$ & $6.67 E+08$ & $\begin{array}{l}6.64 \mathrm{E}-03 \\
8.93 \mathrm{E}-05\end{array}$ \\
\hline EDTA & $8.97 \mathrm{E}+06$ & $\begin{array}{l}8.93 \mathrm{E}-05 \\
3.15 \mathrm{E}-04\end{array}$ \\
\hline & $3.16 \mathrm{E}+07$ & $\begin{array}{l}3.15 \mathrm{E}-04 \\
8.43 \mathrm{E}-04\end{array}$ \\
\hline $\mathrm{Fe}(\mathrm{CN})_{6}$ & $3.83 \mathrm{E}+05$ & $\begin{array}{l}0.43 E-04 \\
3.81 E-06\end{array}$ \\
\hline HEDTA & $1.68 \mathrm{E}+07$ & $1.67 \mathrm{E}-04$ \\
\hline $\mathrm{Hg}$ & $0.00 \mathrm{E}+0 \mathrm{D}$ & $0.00 \mathrm{E}+00$ \\
\hline $\mathrm{K}$ & $2.32 E+07$ & $2.31 E-04$ \\
\hline La & $1.40 \mathrm{E}-10$ & $1.39 \mathrm{E}-21$ \\
\hline$M n$ & $1.32 E+06$ & $1.31 \mathrm{E}-05$ \\
\hline $\mathrm{NO}_{2}$ & $5.52 \mathrm{E}+08$ & $5.50 \mathrm{E}-03$ \\
\hline $\mathrm{NO}_{3}$ & $5.82 E+10$ & $5.80 \mathrm{E}-01$ \\
\hline $\mathrm{Na}$ & $1.93 \mathrm{E}+10$ & 1.92E-01 \\
\hline $\mathrm{Ni}$ & $1.03 E+06$ & $1.02 E-05$ \\
\hline $\mathrm{OH}$ & $3.57 \mathrm{E}+09$ & $3.55 \mathrm{E}-02$ \\
\hline $\mathrm{PO}_{4}$ & $6.95 \mathrm{E}+07$ & $6.92 \mathrm{E}-04$ \\
\hline $\mathrm{Pb}$ & $3.34 \mathrm{E}+06$ & 3. $33 \mathrm{E}-05$ \\
\hline $\mathrm{SeO}_{4}$ & $0.00 \mathrm{E}+00$ & $\begin{array}{l}0.00 \mathrm{E}+00 \\
7.20 \mathrm{E}-04\end{array}$ \\
\hline $\mathrm{SiO}_{\mathrm{S}}$ & $7.23 \mathrm{E}+07$ & $\begin{array}{l}7.20 \mathrm{E}-04 \\
0.00 \mathrm{E}+00\end{array}$ \\
\hline $\mathrm{SO}_{4}$ & $3.84 \mathrm{E}+$ & $3.83 \mathrm{E}-03$ \\
\hline $\mathrm{Sr}$ & 2.71 & $2.70 \mathrm{E}-07$ \\
\hline $\mathrm{HO}_{4}$ & & $0.00 \mathrm{E}+00$ \\
\hline $2 r 0$ & $54 \mathrm{E}+07$ & 4.52 \\
\hline
\end{tabular}


TABLE B.5. Tank Farm T Chemical Inventories from TRAC Output

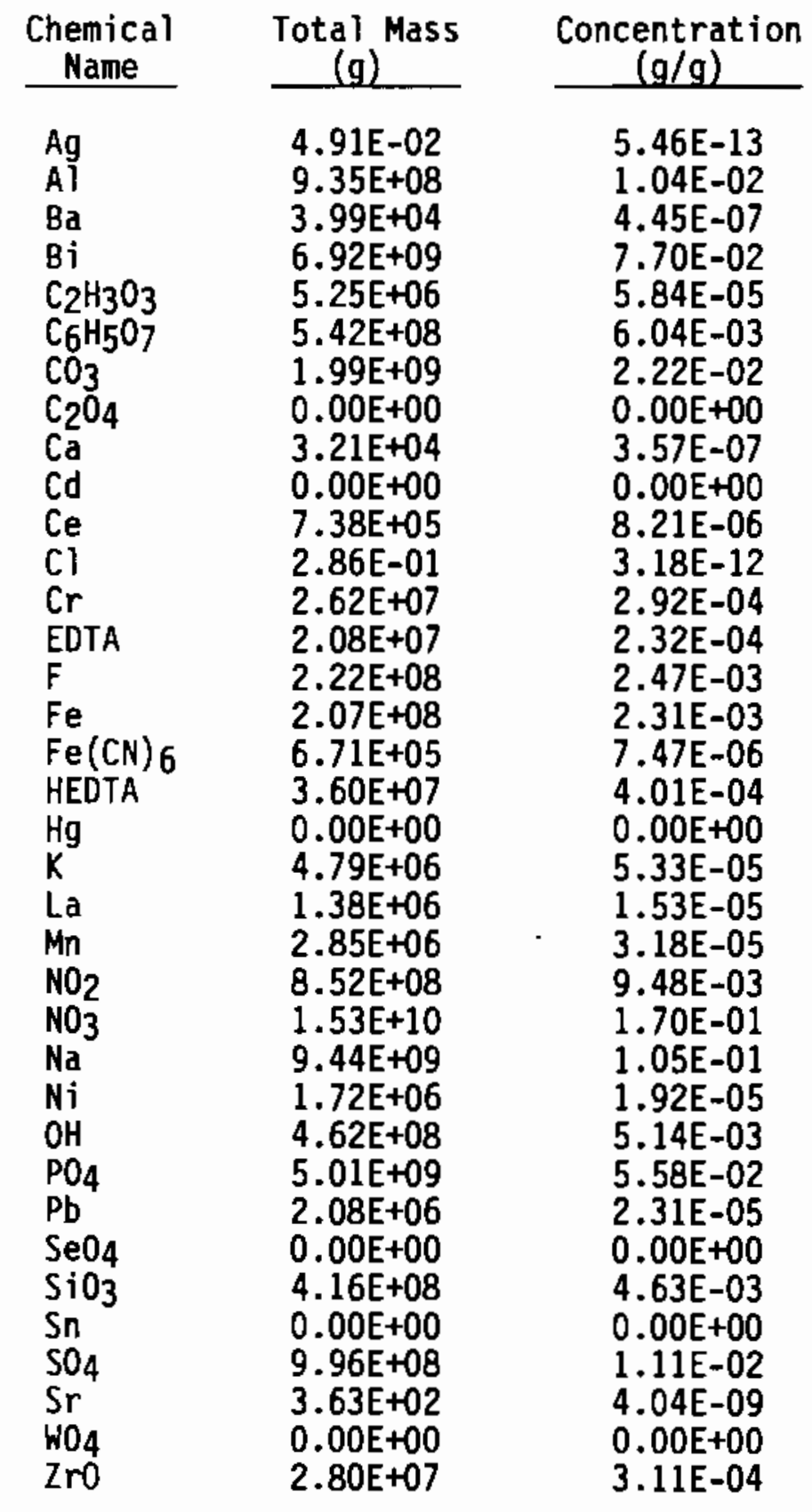


TABLE B.6. Tank Farm U Chemical Inventories from TRAC Output

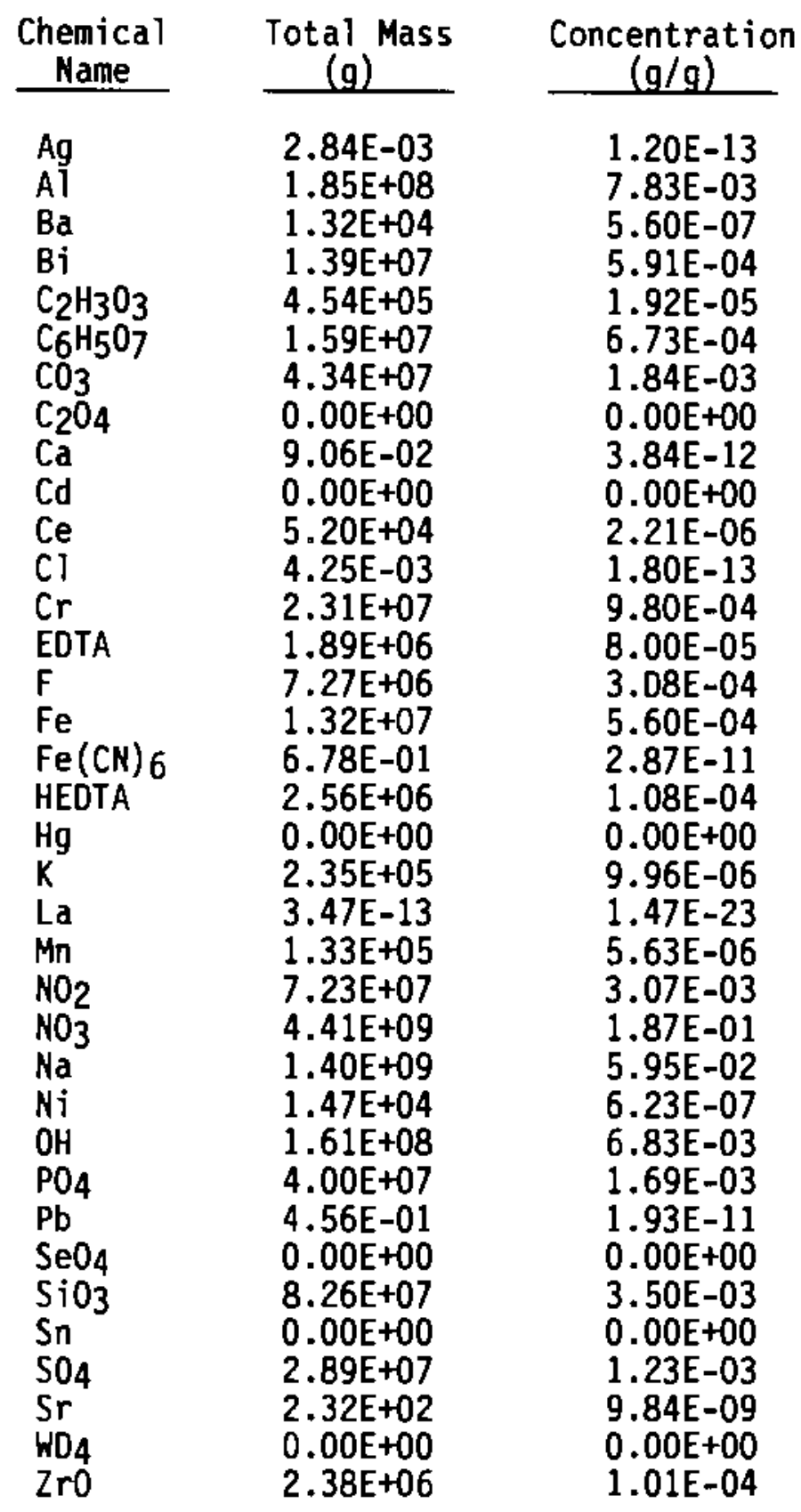


TABLE B.7. TRAC Chemicals Not Included in Modeling for Nonradioactive Impacts

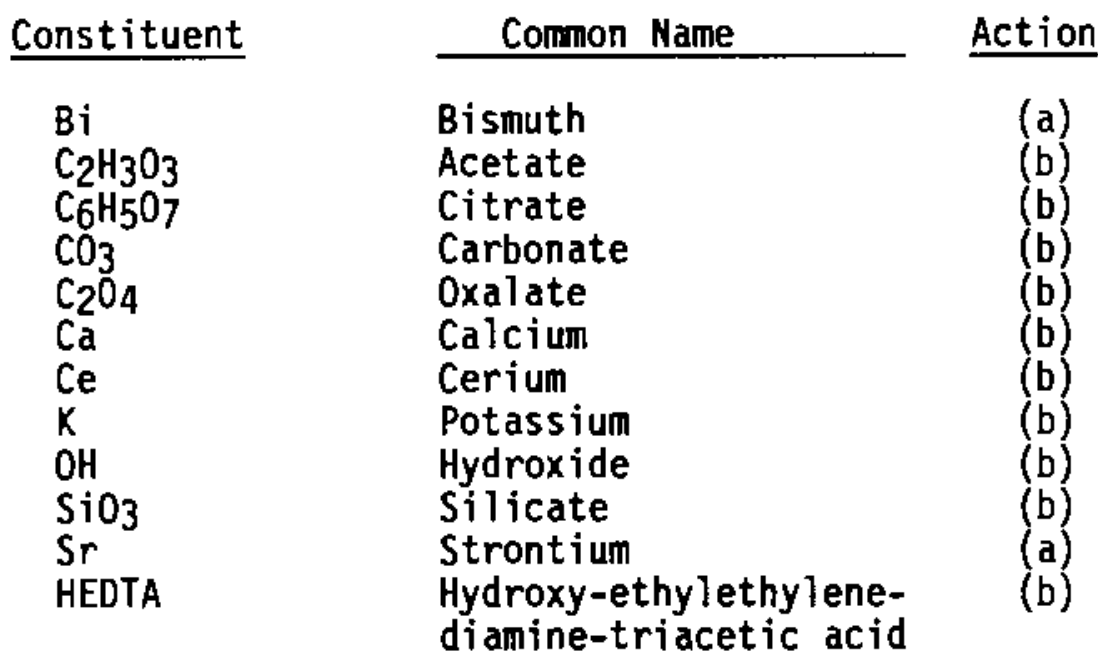

(a) Inadvertently not modeled. Because of its low mobility $\left(K_{d}>10 \mathrm{ml} / \mathrm{g}\right)$ it is not expected to move fast enough to be important.

(b) Physical and/or toxicity properties were either unavailable or questionable from the viewpoint of modeling potential health impacts. 

APPENDIX C

PHYSICAL PARAMETERS FOR CHEMICAL CONSTITUENTS 


\section{APPENDIX C \\ PHYSICAL PARAMETERS FOR CHEMICAL CONSTITUENTS}

TABLE C.1. Physical Parameters for Chemical Constituents

\begin{tabular}{|c|c|c|c|c|}
\hline Constituent & Common Name & $\begin{array}{c}\text { Half-Life } \\
\text { (Years) }\end{array}$ & $\begin{array}{c}K_{d} \\
(m l / g)\end{array}$ & $\begin{array}{c}\text { Solubility } \\
\text { Limit } \\
(\mathrm{g} / \mathrm{ml}) \\
\end{array}$ \\
\hline $\begin{array}{l}\mathrm{Ag} \\
\mathrm{Al} \\
\mathrm{As} \\
\mathrm{Ba} \\
\mathrm{Be} \\
\mathrm{Cd} \\
\mathrm{Cl} \\
\mathrm{Cr} \\
\mathrm{Cu} \\
\mathrm{EDTA} \\
\mathrm{F} \\
\mathrm{Fe} \\
\mathrm{Fe}(\mathrm{CN})_{6} \\
\mathrm{Hg} \\
\mathrm{CN} \\
\mathrm{Mn} \\
\mathrm{NO} 2 \\
\mathrm{NO} 3 \\
\mathrm{Na} \\
\mathrm{Nj} \\
\mathrm{Pb} \\
\mathrm{Sb} \\
\mathrm{Se} \\
\mathrm{SO} 4 \\
\mathrm{~V} \\
\mathrm{ZrO}\end{array}$ & $\begin{array}{l}\text { Silver } \\
\text { Aluminum } \\
\text { Arsenic } \\
\text { Barium } \\
\text { Beryllium } \\
\text { Cadmium } \\
\text { Chloride } \\
\text { Chromium } \\
\text { Copper } \\
\text { E0TAla) } \\
\text { Fluoride } \\
\text { Iron } \\
\text { Ferrocyanide } \\
\text { Mercury } \\
\text { Cyanide } \\
\text { Manganese } \\
\text { Nitrite } \\
\text { Nitrate } \\
\text { Sodium } \\
\text { Nickel } \\
\text { Lead } \\
\text { Antimony } \\
\text { Selenium } \\
\text { Sulfate } \\
\text { Vanadium } \\
\text { Zirconium Oxide }\end{array}$ & $\begin{array}{l}1.0 \mathrm{E}+20 \\
1.0 \mathrm{E}+20 \\
1.0 \mathrm{E}+20 \\
1.0 \mathrm{E}+20 \\
1.0 \mathrm{E}+20 \\
1.0 \mathrm{E}+20 \\
1.0 \mathrm{E}+20 \\
1.0 \mathrm{E}+20 \\
1.0 \mathrm{E}+20 \\
1.0 \mathrm{E}+20 \\
1.0 \mathrm{E}+20 \\
1.0 \mathrm{E}+20 \\
1.0 \mathrm{E}+20 \\
1.0 \mathrm{E}+20 \\
1.0 \mathrm{E}+20 \\
1.0 \mathrm{E}+20 \\
1.0 \mathrm{E}+20 \\
1.0 \mathrm{E}+20 \\
1.0 \mathrm{E}+20 \\
1.0 \mathrm{E}+20 \\
1.0 \mathrm{E}+20 \\
1.0 \mathrm{E}+20 \\
1.0 \mathrm{E}+20 \\
1.0 \mathrm{E}+20 \\
1.0 \mathrm{E}+20 \\
1.0 \mathrm{E}+20\end{array}$ & $\begin{array}{r}0.4 \\
353.0 \\
0.6 \\
530.0 \\
0.0 \\
3.0 \\
0.0 \\
1.0 \\
4.2 \\
0.0 \\
0.0 \\
1.5 \\
0.0 \\
0.0 \\
0.0 \\
16.5 \\
0.0 \\
0.0 \\
0.0 \\
1.2 \\
234.0 \\
0.0 \\
5.9 \\
0.0 \\
0.0 \\
5.0\end{array}$ & $\begin{array}{l}1.76 \mathrm{E}-06 \\
3.41 \mathrm{E}-04 \\
3.45 \mathrm{E}-04 \\
7.44 \mathrm{E}-06 \\
9.04 \mathrm{E}-04 \\
3.45 \mathrm{E}-03 \\
1.35 \mathrm{E}-02 \\
1.42 \mathrm{E}-03 \\
3.45 \mathrm{E}-03 \\
2.81 \mathrm{E}-05 \\
3.55 \mathrm{E}-03 \\
1.99 \mathrm{E}-04 \\
1.10 \mathrm{E}-06 \\
3.20 \mathrm{E}-04 \\
1.10 \mathrm{E}-06 \\
1.42 \mathrm{E}-05 \\
1.25 \mathrm{E}-01 \\
1.31 \mathrm{E}-02 \\
9.19 \mathrm{E}-02 \\
2.32 \mathrm{E}-05 \\
7.71 \mathrm{E}-06 \\
8.46 \mathrm{E}-03 \\
8.46 \mathrm{E}-03 \\
8.46 \mathrm{E}-03 \\
8.46 \mathrm{E}-03 \\
3.45 \mathrm{E}-04\end{array}$ \\
\hline
\end{tabular}

(a) Ethylenediaamine-tetracetic acid 



\section{APPENDIX D}

RADIONUCLIDE FLUX RATES AND RELEASE DURATION 


\section{APPENDIX D \\ RADIONUCLIDE FLUX RATES AND RELEASE DURATION}

TABLE D.1. $\mathrm{NaNO}_{3}$ Congruent Radionuclide Release Rates at $0.5 \mathrm{~cm} / \mathrm{yr}$ Recharge (a)

\begin{tabular}{|c|c|c|c|c|}
\hline Area & Tank Farm & $\begin{array}{r}\mathrm{NaNO}_{3} \\
(\mathrm{~g}) \\
\end{array}$ & $\begin{array}{l}\text { Flux Rate } \\
(\mathrm{L} / \mathrm{yr})\end{array}$ & $\begin{array}{l}\text { Leach Time } \\
\frac{(y r)}{}\end{array}$ \\
\hline 200 East & A Farm & $5.44 \mathrm{E}+10$ & $2.06 \mathrm{E}+04$ & 2870 \\
\hline 200 East & B Farm & $5.70 E+10$ & $7.45 E+04$ & 831 \\
\hline 200 East & C Farm & $7.96 \mathrm{E}+09$ & $2.53 E+04$ & 342 \\
\hline 200 West & S Farm & $7.15 \mathrm{E}+10$ & $5.55 E+04$ & 1399 \\
\hline 200 West & T Farm & $2.10 \mathrm{E}+10$ & $7.45 \mathrm{E}+04$ & 306 \\
\hline 200 West & U Farm & $5.19 E+09$ & $2.53 \mathrm{E}+04$ & 223 \\
\hline
\end{tabular}

(a) Solubility of $\mathrm{NaNO}_{3}=921 \mathrm{~g} / \mathrm{L}$.

TABLE D.2. $\mathrm{NaNO}_{3}$ Congruent Radionuclide Release Rates at $1.0 \mathrm{~cm} / \mathrm{yr}$ Recharge(a)

\begin{tabular}{|c|c|c|c|c|}
\hline Area & Tank Farm & $\begin{array}{c}\mathrm{NaNO}_{3} \\
(\mathrm{~g})\end{array}$ & $\begin{array}{c}\text { Flux Rate } \\
\text { (L/yr) }\end{array}$ & $\begin{array}{l}\text { Leach Time } \\
(y r)\end{array}$ \\
\hline 200 East & A Farm & $5.44 \mathrm{E}+10$ & $4.12 E+04$ & 1433 \\
\hline 200 East & B Farm & $5.70 E+10$ & $1.49 \mathrm{E}+05$ & 415 \\
\hline 200 East & C Farm & $7.96 \mathrm{E}+09$ & $5.06 \mathrm{E}+04$ & 171 \\
\hline 200 West & $S$ Farm & $7.15 \mathrm{E}+10$ & $1.11 E+D 5$ & 699 \\
\hline 200 West & T Farm & $2.10 \mathrm{E}+10$ & $1.49 E+05$ & 153 \\
\hline 200 West & U Farm & $5.19 E+09$ & $5.06 \mathrm{E}+04$ & 111 \\
\hline
\end{tabular}

(a) Solubility of $\mathrm{NaNO}_{3}=921 \mathrm{~g} / \mathrm{L}$. 
IABLE D.3. $\mathrm{NaNO}_{3}$ Congruent Radionuclide Release Rates at $10.0 \mathrm{~cm} / \mathrm{yr}$ Recharge (a)

$\begin{array}{ccccc}\text { Area } & \text { Iank Farm } & \frac{\mathrm{NaNO}_{3}}{(\mathrm{~g})} & \frac{\begin{array}{c}\text { Flux Rate } \\ (\mathrm{L} / \mathrm{yr})\end{array}}{2} & \begin{array}{c}\text { Leach Time } \\ \text { (yr) }\end{array} \\ 200 \text { East } & \text { A Farm } & 5.44 \mathrm{E}+10 & 4.12 \mathrm{E}+05 & 143 \\ 200 \text { East } & \text { B Farm } & 5.70 \mathrm{E}+10 & 1.49 \mathrm{E}+06 & 41 \\ 200 \text { East } & \text { C Farm } & 7.96 \mathrm{E}+09 & 5.06 \mathrm{E}+05 & 17 \\ 200 \text { West } & \text { S Farm } & 7.15 \mathrm{E}+10 & 1.11 \mathrm{E}+06 & 69 \\ 200 \text { West } & \text { T Farm } & 2.10 \mathrm{E}+10 & 1.49 \mathrm{E}+06 & 15 \\ 200 \text { West } & \text { U Farm } & 5.19 \mathrm{E}+09 & 5.06 \mathrm{E}+05 & 11\end{array}$

(a) Solubility of $\mathrm{NaNO}_{3}=921 \mathrm{~g} / \mathrm{L}$. 


\section{APPENDIX E}

SINGLE-SHELL TANK HYDROLOGIC PARAMETERS 


\section{APPENDIX E \\ SINGLE-SHELL TANK HYDROLOGIC PARAMETERS}

TABLE E.1. Composite Textural Data Used to Model SST Releases in 200 East Area A Farm, Area $=6.42 \mathrm{E}+01 \mathrm{~cm} \times 6.42 \mathrm{E}+01 \mathrm{~cm}$

\begin{tabular}{|c|c|c|c|c|c|c|}
\hline Layer (a) & $\begin{array}{c}\text { Textural } \\
\text { Name } \\
\end{array}$ & $\begin{array}{l}\text { Thickness } \\
(\mathrm{cm})\end{array}$ & $\begin{array}{l}\text { Bulk } \\
\text { Density } \\
\left(\mathrm{g} / \mathrm{cm}^{3}\right) \\
\end{array}$ & $\begin{array}{l}\text { Porosity } \\
\left(\frac{8}{6}\right)\end{array}$ & $\begin{array}{c}\text { Field } \\
\text { Capacity } \\
(\%) \\
\end{array}$ & $\begin{array}{c}\text { Hydraulic } \\
\text { Conductivity } \\
\text { (cm/day) } \\
\end{array}$ \\
\hline PSZ & Sandy loam & 457.2 & 1.48 & 44.2 & 17.0 & 1,500 \\
\hline PSZ 2 & Sand & $8,077.2$ & 1.64 & 38.0 & 9.0 & 88,000 \\
\hline$S Z$ & Sand & 457.2 & 1.64 & 38.0 & 9.0 & 88,000 \\
\hline
\end{tabular}

(a) PSZ = Partially Saturated Zone, SZ = Saturated Zone.

TABLE E.2. Composite Textural Data Used to Model SST Releases in 200 East Area - B Farm, Area $=1.22 \mathrm{E}+02 \mathrm{~cm} \times 1.22 \mathrm{E}+02 \mathrm{~cm}$

\begin{tabular}{|c|c|c|c|c|c|c|}
\hline Layer(a) & $\begin{array}{c}\text { Textural } \\
\text { Name }\end{array}$ & $\begin{array}{l}\text { Thickness } \\
\text { (cm) } \\
\end{array}$ & $\begin{array}{l}\text { Bulk } \\
\text { Density } \\
\left(\mathrm{g} / \mathrm{cm}^{3}\right) \\
\end{array}$ & $\begin{array}{c}\text { Porosity } \\
\left(\frac{\%}{6}\right) \\
\end{array}$ & $\begin{array}{l}\text { Field } \\
\text { Capacity } \\
(\%) \\
\end{array}$ & $\begin{array}{l}\text { Hydraulic } \\
\text { Conductivity } \\
\text { (cm/day) } \\
\end{array}$ \\
\hline PSZ & Sand & 5,000 & 1.64 & 38.0 & 9.0 & 88,000 \\
\hline PSZ & Loamy sand & 150 & 1.49 & 43.7 & 12.0 & 9,900 \\
\hline PSZ & Sand & 2,680 & 1.64 & 38.0 & 9.0 & 88,000 \\
\hline $5 Z$ & Sand & 457.2 & 1.64 & 38.0 & 9.0 & 88,000 \\
\hline
\end{tabular}

(a) PSZ = Partially Saturated Zone, SZ = Saturated Zone. 
IABLE E.3. Composite Textural Data Used to Model SST Releases in 200 East Area C Farm, Area $=7.11 \mathrm{E}+01 \mathrm{~cm} \times 7.11 \mathrm{E}+01 \mathrm{~cm}$

\begin{tabular}{|c|c|c|c|c|c|c|}
\hline Layer $(\mathrm{a})$ & $\begin{array}{c}\text { Textural } \\
\text { Name } \\
\end{array}$ & $\begin{array}{l}\text { Thickness } \\
\text { (cm) }\end{array}$ & $\begin{array}{l}\text { Bulk } \\
\text { Density } \\
\left(\mathrm{g} / \mathrm{cm}^{3}\right)\end{array}$ & $\begin{array}{c}\text { Porosity } \\
\left(\frac{6}{6}\right)\end{array}$ & $\begin{array}{c}\text { Field } \\
\text { Capacity } \\
(\%)\end{array}$ & $\begin{array}{l}\text { Hydraulic } \\
\text { Conductivity } \\
\text { (cm/day) } \\
\end{array}$ \\
\hline PSZ 1 & Sand & $8,534.4$ & 1.64 & 38.0 & 9.0 & 88,000 \\
\hline$S Z$ & Sand & 457.2 & 1.64 & 38.0 & 9.0 & 88,000 \\
\hline
\end{tabular}

(a) PSZ = Partially Saturated Zone, SZ = Saturated Zone.

IABLE E.4. Composite Textural Data Used to Mode 1 SST Releases in 200 West Area $S$ Farm, Area $=1.05 \mathrm{E}+02 \mathrm{~cm} \times 1.05 \mathrm{E}+02 \mathrm{~cm}$

\begin{tabular}{|c|c|c|c|c|c|c|}
\hline Layer (a & $\begin{array}{c}\text { Textural } \\
\text { Name }\end{array}$ & $\begin{array}{l}\text { Thickness } \\
\text { (cm) } \\
\end{array}$ & $\begin{array}{l}\text { Bulk } \\
\text { Density } \\
\left(\mathrm{g} / \mathrm{cm}^{3}\right)\end{array}$ & $\begin{array}{c}\text { Porosity } \\
(\%)\end{array}$ & $\begin{array}{c}\text { Field } \\
\text { Capacity } \\
\left(\frac{q}{6}\right) \\
\end{array}$ & $\begin{array}{c}\text { Hydraulic } \\
\text { Conductivity } \\
\text { (cm/day) } \\
\end{array}$ \\
\hline PSZ & Loamy sand & $2,743.2$ & 1.49 & 43.7 & 12.0 & 9,900 \\
\hline PSZ & Sandy loam & 1,524 & 1.48 & 44.2 & 17.0 & 1,500 \\
\hline PSZ & $\begin{array}{l}\text { Sandy clay } \\
\text { loam }\end{array}$ & 762 & 1.60 & 39.8 & 24.0 & 49 \\
\hline PSZ & Clay loam & 304.8 & 1.39 & 47.7 & 34.0 & 15 \\
\hline PSZ & Clay & 152.4 & 1.39 & 47.5 & 40.0 & 2.4 \\
\hline PSZ & Sand & 914.4 & 1.64 & 38.0 & 9.0 & 88,000 \\
\hline$S Z$ & Sand & 457.2 & 1.64 & 38.0 & 9.0 & 88,000 \\
\hline
\end{tabular}

(a) PSZ = Partially Saturated Zone, SZ = Saturated Zone. 
TABLE E.5. Composite Textural Data Used to Model SST Releases in 200 West Area T Farm, Area $=1.22 \mathrm{E}+02 \mathrm{~cm} \times 1.22 \mathrm{E}+02 \mathrm{~cm}$

\begin{tabular}{|c|c|c|c|c|c|c|c|}
\hline \multicolumn{2}{|c|}{ Layer (a) } & $\begin{array}{c}\text { Textural } \\
\text { Name } \\
\end{array}$ & $\begin{array}{l}\text { Thickness } \\
\text { (cm) }\end{array}$ & $\begin{array}{c}\text { Bulk } \\
\text { Density } \\
\left.\text { (g/ } / \mathrm{cm}^{3}\right)\end{array}$ & $\begin{array}{l}\text { Porosity } \\
\left(\frac{\circ}{6}\right)\end{array}$ & $\begin{array}{c}\text { Field } \\
\text { Capacity } \\
(\%) \\
\end{array}$ & $\begin{array}{c}\text { Hydraulic } \\
\text { Conductivity } \\
\text { (cm/day) } \\
\end{array}$ \\
\hline PSZ & 1 & Sand & 3,048 & 1.64 & 38.0 & 9.0 & 88,000 \\
\hline PSZ & 2 & $\begin{array}{l}\text { Sandy clay } \\
\text { loam }\end{array}$ & 157.4 & 1.60 & 39.8 & 24.0 & 49 \\
\hline PSZ & 3 & Sandy loam & 609.6 & 1.48 & 44.2 & 17.0 & 1500 \\
\hline PSZ & 4 & Loamy sand & $2,438.4$ & 1.49 & 43.7 & 12.0 & 9,900 \\
\hline SZ & & Loamy sand & 457.2 & 1.64 & 38.0 & 9.0 & 88,000 \\
\hline
\end{tabular}

(a) PSZ = Partially Saturated Zone, SZ = Saturated Zone.

TABLE E.6. Composite Textural Data Used to Model

SST Releases in 200 West Area -

U Farm, Area $=7.11 \mathrm{E}+01 \mathrm{~cm} \times 7.11 \mathrm{E}+01 \mathrm{~cm}$

\begin{tabular}{|c|c|c|c|c|c|c|}
\hline Layer (a) & $\begin{array}{c}\text { Textural } \\
\text { Name }\end{array}$ & $\begin{array}{l}\text { Thickness } \\
\text { (cm) }\end{array}$ & $\begin{array}{l}\text { Bulk } \\
\text { Density } \\
\text { (g/cm } 3 \text { ) }\end{array}$ & $\begin{array}{c}\text { Porosity } \\
\left(\frac{\circ}{6}\right)\end{array}$ & $\begin{array}{c}\text { Field } \\
\text { Capacity } \\
\left(\frac{\%}{6}\right) \\
\end{array}$ & $\begin{array}{l}\text { Hydraulic } \\
\text { Conductivity } \\
\text { (cm/day) }\end{array}$ \\
\hline PSZ & Sand & 4,420 & 1.64 & 38.0 & 9.0 & 88,000 \\
\hline PSZ & $\begin{array}{l}\text { Sandy clay } \\
\text { loam }\end{array}$ & 457 & 1.60 & 39.8 & 24.0 & 49 \\
\hline PSZ & Clay loam & 152 & 1.39 & 47.7 & 34.0 & 15 \\
\hline PSZ & Loamy sand & 935 & 1.49 & 43.7 & 12.0 & 9,900 \\
\hline$S Z$ & Loamy sand & 457.2 & 1.64 & 38.0 & 9.0 & 88,000 \\
\hline
\end{tabular}

(a) PSZ = Partially Saturated Zone, SZ = Saturated Zone.

TABLE E.7. Saturated Zone

\begin{tabular}{|c|c|c|}
\hline Area & Tank Farms & $\begin{array}{l}\text { Pore Water Velocity } \\
\text { (cm/day) }\end{array}$ \\
\hline $\begin{array}{l}200 \text { West } \\
200 \text { East }\end{array}$ & $\begin{array}{l}S, T, U \\
A, B, C\end{array}$ & $\begin{array}{r}30 \\
150\end{array}$ \\
\hline
\end{tabular}





\section{APPENDIX $F$}

PHYSICAL PARAMETERS FOR RADIONUCLIDES 


\section{APPENDIX $F$}

PHYSICAL PARAMETERS FOR RADIONUCLIDES

IABLE F.1. Physical Parameters for Radionuclide Constituents

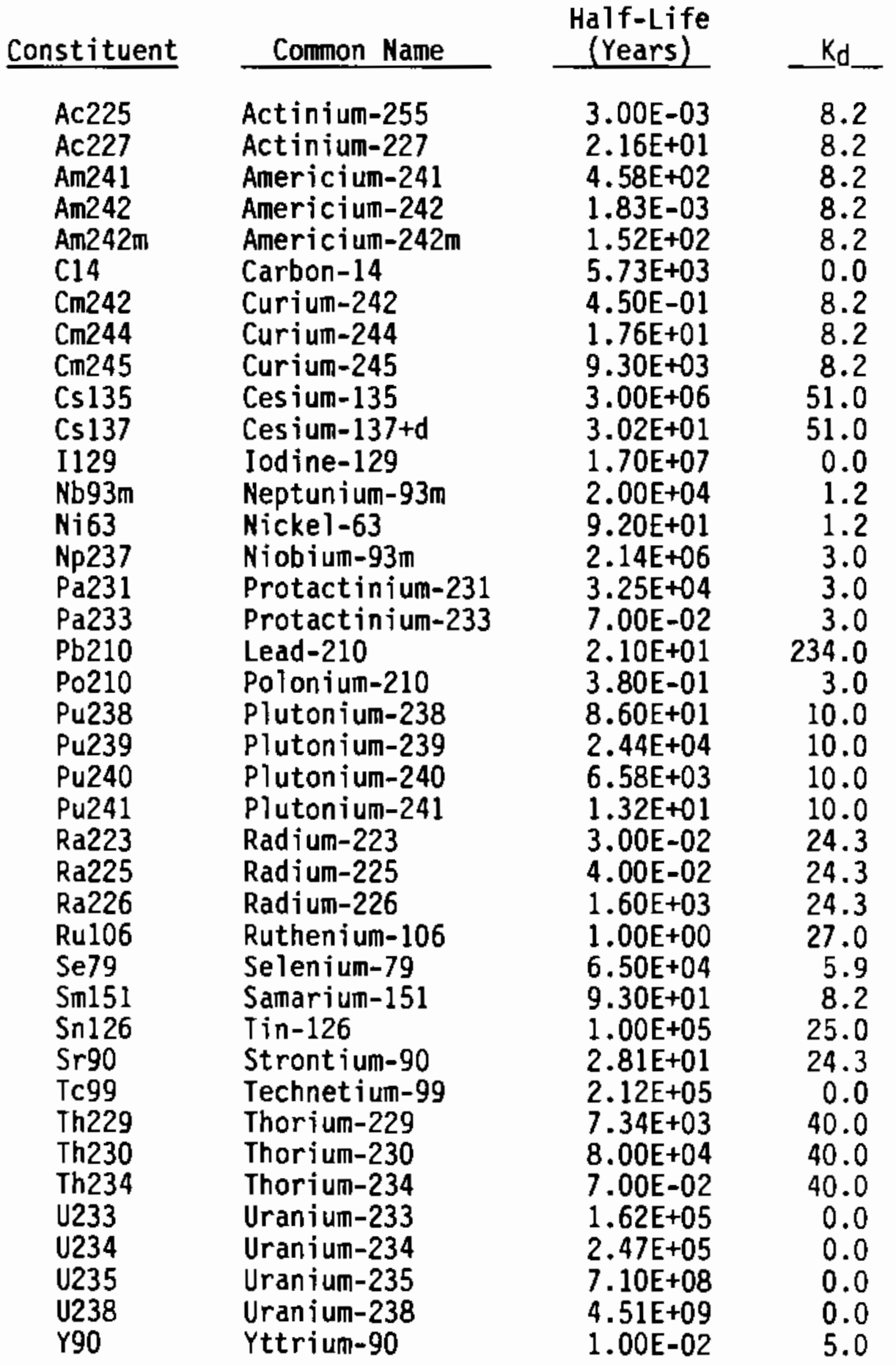



APPENDIX $\mathrm{G}$

PEAK CONCENTRATIONS COMPUTED IN HYPOTHETICAL WELLS 
APPENDIX G

\section{PEAK CONCENTRATIONS COMPUTED IN HYPOTHETICAL WELLS}

This appendix contains sumaries of the computed peak concentrations in the well and the arrival times for these peaks. These lists are direct outputs of the constituent transport modeling effort. The radionuclides given in Tables G.1 and G.2 contain entries for parent and decay products (indicated with *). Some materials appear several times in different decay chains. Tables G.3, G.4, G.5, and G.6 show the chemicals that were modeled. 
TABLE G.1. Peak Concentrations in well Using $10 \mathrm{~cm} / \mathrm{yr}$ Recharge for Radionuclide Constituents

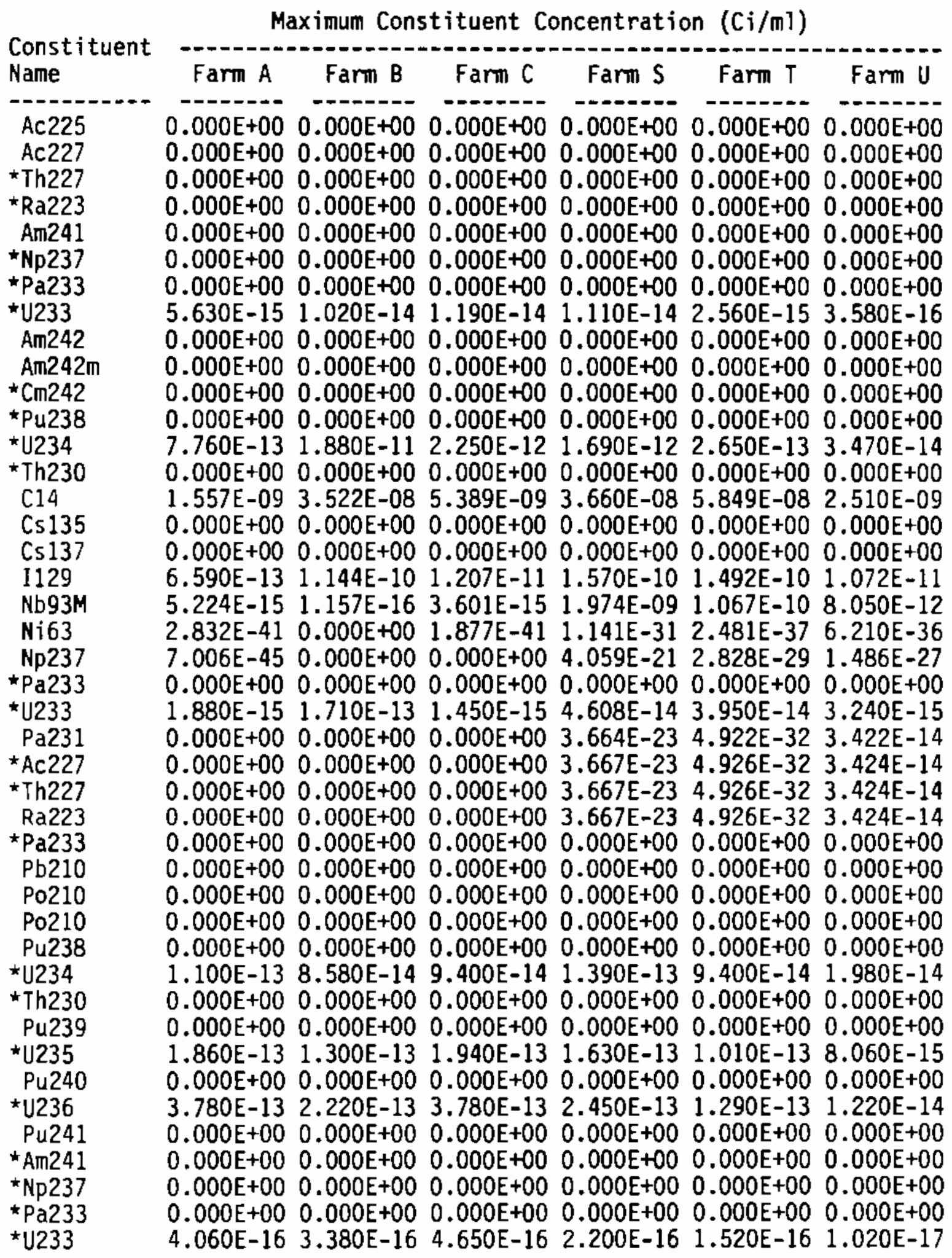


TABLE G.1. (contd)

Maximum Constituent Concentration $(\mathrm{Ci} / \mathrm{ml})$

Const ituent

Name

Farm

Farm B

Farm $C$ Farm $S$

Farm $\mathrm{T}$

Farm U

$\operatorname{Ra} 223$

$\begin{array}{llllllll}0.000 E+00 & 0.000 E+00 & 0.000 E+00 & 0.000 E+00 & 0.000 E+00 & 0.000 E+00\end{array}$

$\operatorname{Ra} 225$

Ra226

$\mathrm{Pb} 210$

Po210

Ru106

Se79

Sm151

Sn126

Sr90

*Y90

Tc99

Th229

Ra225

Ac225

Th230

Th234

U233

*Th229

*Ra225

*Ac225

Cा1242

*Pu238

*U234

*Th230

Cm244

* Pu240

*U236

Cा1245

*Pu24:

*Am24:

*Np237

^Pa233

*U233

U234

*Th230

U235

*Pa231

*Ac227

*Th227

*Ra223

U238

*Th234

Y90

$\begin{array}{lllllll}0.000 \mathrm{E}+00 & 0.000 \mathrm{E}+00 & 0.000 \mathrm{E}+00 & 0.000 \mathrm{E}+00 & 0.000 \mathrm{E}+00 & 0.000 \mathrm{E}+00\end{array}$

$\begin{array}{lllllll}0.000 \mathrm{E}+00 & 0.000 \mathrm{E}+00 & 0.000 \mathrm{E}+00 & 0.000 \mathrm{E}+00 & 0.000 \mathrm{E}+00 & 0.000 \mathrm{E}+00\end{array}$

$\begin{array}{lllllll}0.000 \mathrm{E}+00 & 0.000 \mathrm{E}+00 & 0.000 \mathrm{E}+00 & 0.000 \mathrm{E}+00 & 0.000 \mathrm{E}+00 & 0.000 \mathrm{E}+00\end{array}$

$\begin{array}{llllllll}0.000 \mathrm{E}+00 & 0.000 \mathrm{E}+00 & 0.000 \mathrm{E}+00 & 0.000 \mathrm{E}+00 & 0.000 \mathrm{E}+00 & 0.000 \mathrm{E}+00\end{array}$

$\begin{array}{llllllll}0.000 \mathrm{E}+00 & 0.000 \mathrm{E}+00 & 0.000 \mathrm{E}+00 & 0.000 \mathrm{E}+00 & 0.000 \mathrm{E}+00 & 0.000 \mathrm{E}+00\end{array}$

$\begin{array}{llllllllllll}0.000 \mathrm{E}+00 & 0.000 \mathrm{E}+00 & 0.000 \mathrm{E}+00 & 0.000 \mathrm{E}+00 & 0.000 \mathrm{E}+00 & 0.000 \mathrm{E}+00\end{array}$ $\begin{array}{llllllll}0.000 \mathrm{E}+00 & 0.000 \mathrm{E}+00 & 0.000 \mathrm{E}+00 & 0.000 \mathrm{E}+00 & 0.000 \mathrm{E}+00 & 0.000 \mathrm{E}+00\end{array}$ $\begin{array}{llllllllll}0.000 \mathrm{E}+00 & 0.000 \mathrm{E}+00 & 0.000 \mathrm{E}+00 & 0.000 \mathrm{E}+00 & 0.000 \mathrm{E}+00 & 0.000 \mathrm{E}+00\end{array}$ $\begin{array}{llllllllll}0.000 \mathrm{E}+00 & 0.000 \mathrm{E}+00 & 0.000 \mathrm{E}+00 & 0.000 \mathrm{E}+00 & 0.000 \mathrm{E}+00 & 0.000 \mathrm{E}+00\end{array}$ $\begin{array}{llllllll}0.000 \mathrm{E}+00 & 0.000 \mathrm{E}+00 & 0.000 \mathrm{E}+00 & 0.000 \mathrm{E}+00 & 0.000 \mathrm{E}+00 & 0.000 \mathrm{E}+00\end{array}$ 4.468E-10 7.018E-08 6.089E-09 9.540E-08 $1.141 \mathrm{E}-07 \quad 7.739 \mathrm{E}-09$ $\begin{array}{lllllllllllll}0.000 \mathrm{E}+00 & 0.000 \mathrm{E}+00 & 0.000 \mathrm{E}+00 & 0.000 \mathrm{E}+00 & 0.000 \mathrm{E}+00 & 0.000 \mathrm{E}+00\end{array}$ $\begin{array}{lllllllllll}0.000 \mathrm{E}+00 & 0.000 \mathrm{E}+00 & 0.000 \mathrm{E}+00 & 0.000 \mathrm{E}+00 & 0.000 \mathrm{E}+00 & 0.000 \mathrm{E}+00\end{array}$ $\begin{array}{llllllllll}0.000 \mathrm{E}+00 & 0.000 \mathrm{E}+00 & 0.000 \mathrm{E}+00 & 0.000 \mathrm{E}+00 & 0.000 \mathrm{E}+00 & 0.000 \mathrm{E}+00\end{array}$ $\begin{array}{llllllll}0.000 \mathrm{E}+00 & 0.000 \mathrm{E}+00 & 0.000 \mathrm{E}+00 & 0.000 \mathrm{E}+00 & 0.000 \mathrm{E}+00 & 0.000 \mathrm{E}+00\end{array}$ $\begin{array}{lllllllllll}0.000 \mathrm{E}+00 & 0.000 \mathrm{E}+00 & 0.000 \mathrm{E}+00 & 0.000 \mathrm{E}+00 & 0.000 \mathrm{E}+00 & 0.000 \mathrm{E}+00\end{array}$ $1.627 \mathrm{E}-15 \quad 1.783 \mathrm{E}-14 \quad 3.825 \mathrm{E}-15 \quad 1.570 \mathrm{E}-14 \quad 3.258 \mathrm{E}-14 \quad 5.037 \mathrm{E}-15$ $\begin{array}{llllll}0.000 \mathrm{E}+00 & 0.000 \mathrm{E}+00 & 0.000 \mathrm{E}+00 & 0.000 \mathrm{E}+00 & 0.000 \mathrm{E}+00 & 0.000 \mathrm{E}+00\end{array}$ $\begin{array}{lllllllll}0.000 \mathrm{E}+00 & 0.000 \mathrm{E}+00 & 0.000 \mathrm{E}+00 & 0.000 \mathrm{E}+00 & 0.000 \mathrm{E}+00 & 0.000 \mathrm{E}+00\end{array}$ $\begin{array}{llllllllll}0.000 \mathrm{E}+00 & 0.000 \mathrm{E}+00 & 0.000 \mathrm{E}+00 & 0.000 \mathrm{E}+00 & 0.000 \mathrm{E}+00 & 0.000 \mathrm{E}+00\end{array}$ $\begin{array}{llllllllllll}0.000 E+00 & 0.000 E+00 & 0.000 E+00 & 0.000 E+00 & 0.000 E+00 & 0.000 E+00\end{array}$ $\begin{array}{lllllllllll}0.000 E+00 & 0.000 E+00 & 0.000 E+00 & 0.000 E+00 & 0.000 E+00 & 0.000 E+00\end{array}$ $1.210 \mathrm{E}-142.870 \mathrm{E}-14 \quad 2.460 \mathrm{E}-14 \quad 2.460 \mathrm{E}-14 \quad 4.720 \mathrm{E}-14 \quad 6.150 \mathrm{E}-16$ $\begin{array}{llllllllll}0.000 \mathrm{E}+00 & 0.000 \mathrm{E}+00 & 0.000 \mathrm{E}+00 & 0.000 \mathrm{E}+00 & 0.000 \mathrm{E}+00 & 0.000 \mathrm{E}+00\end{array}$ $\begin{array}{lllllllllllll}0.000 \mathrm{E}+00 & 0.000 \mathrm{E}+00 & 0.000 \mathrm{E}+00 & 0.000 \mathrm{E}+00 & 0.000 \mathrm{E}+00 & 0.000 \mathrm{E}+00\end{array}$ $\begin{array}{lllllllllll}0.000 \mathrm{E}+00 & 0.000 \mathrm{E}+00 & 0.000 \mathrm{E}+00 & 0.000 \mathrm{E}+00 & 0.000 \mathrm{E}+00 & 0.000 \mathrm{E}+00\end{array}$ $6.270 \mathrm{E}-18 \quad 3.550 \mathrm{E}-17 \quad 4.810 \mathrm{E}-17 \quad 1.670 \mathrm{E}-17 \quad 2.300 \mathrm{E}-18 \quad 2.720 \mathrm{E}-19$ $\begin{array}{llllllll}0.000 \mathrm{E}+00 & 0.000 \mathrm{E}+00 & 0.000 \mathrm{E}+00 & 0.000 \mathrm{E}+00 & 0.000 \mathrm{E}+00 & 0.000 \mathrm{E}+00\end{array}$ $\begin{array}{llllllllllll}0.000 \mathrm{E}+00 & 0.000 \mathrm{E}+00 & 0.000 \mathrm{E}+00 & 0.000 \mathrm{E}+00 & 0.000 \mathrm{E}+00 & 0.000 \mathrm{E}+00\end{array}$ $\begin{array}{lllllllll}0.000 E+00 & 0.000 E+00 & 0.000 E+00 & 0.000 E+00 & 0.000 E+00 & 0.000 E+00\end{array}$ $\begin{array}{lllllllllll}0.000 \mathrm{E}+00 & 0.000 \mathrm{E}+00 & 0.000 \mathrm{E}+00 & 0.000 \mathrm{E}+00 & 0.000 \mathrm{E}+00 & 0.000 \mathrm{E}+00\end{array}$ $\begin{array}{lllllllllll}0.000 \mathrm{E}+00 & 0.000 \mathrm{E}+00 & 0.000 \mathrm{E}+00 & 0.000 \mathrm{E}+00 & 0.000 \mathrm{E}+00 & 0.000 \mathrm{E}+00\end{array}$ $\begin{array}{llllllllll}0.000 \mathrm{E}+00 & 0.000 \mathrm{E}+00 & 0.000 \mathrm{E}+00 & 0.000 \mathrm{E}+00 & 0.000 \mathrm{E}+00 & 0.000 \mathrm{E}+00\end{array}$ $2.866 \mathrm{E}-14 \quad 1.730 \mathrm{E}-13 \quad 1.418 \mathrm{E}-13 \quad 4.160 \mathrm{E}-13 \quad 1.280 \mathrm{E}-12 \quad 2.464 \mathrm{E}-13$ $\begin{array}{lllllllllllllll}0.000 \mathrm{E}+00 & 0.000 \mathrm{E}+00 & 0.000 \mathrm{E}+00 & 0.000 \mathrm{E}+00 & 0.000 \mathrm{E}+00 & 0.000 \mathrm{E}+00\end{array}$ $1.035 \mathrm{E}-12 \quad 3.455 \mathrm{E}-11 \quad 1.346 \mathrm{E}-11 \quad 2.070 \mathrm{E}-11 \quad 2.318 \mathrm{E}-10 \quad 3.835 \mathrm{E}-11$ $\begin{array}{lllllll}0.000 \mathrm{E}+00 & 0.000 \mathrm{E}+00 & 0.000 \mathrm{E}+00 & 0.000 \mathrm{E}+00 & 0.000 \mathrm{E}+00 & 0.000 \mathrm{E}+00\end{array}$ $\begin{array}{lllllllll}0.000 \mathrm{E}+00 & 0.000 \mathrm{E}+00 & 0.000 \mathrm{E}+00 & 0.000 \mathrm{E}+00 & 0.000 \mathrm{E}+00 & 0.000 \mathrm{E}+00\end{array}$ $\begin{array}{llllll}0.000 \mathrm{E}+00 & 0.000 \mathrm{E}+00 & 0.000 \mathrm{E}+00 & 0.000 \mathrm{E}+00 & 0.000 \mathrm{E}+00 & 0.000 \mathrm{E}+00\end{array}$ $\begin{array}{lllllll}0.000 E+00 & 0.000 E+00 & 0.000 E+00 & 0.000 E+00 & 0.000 E+00 & 0.000 E+00\end{array}$ $2.270 \mathrm{E}-11 \quad 7.889 \mathrm{E}-10 \quad 3.472 \mathrm{E}-10 \quad 4.170 \mathrm{E}-10 \quad 5.789 \mathrm{E}-09 \quad 1.099 \mathrm{E}-09$ $\begin{array}{llllllll}0.000 \mathrm{E}+00 & 0.000 \mathrm{E}+00 & 0.000 \mathrm{E}+00 & 0.000 \mathrm{E}+00 & 0.000 \mathrm{E}+00 & 0.000 \mathrm{E}+00\end{array}$ $\begin{array}{llll}0.000 \mathrm{E}+00 & 0.000 \mathrm{E}+00 \quad 0.000 \mathrm{E}+00 \quad 0.000 \mathrm{E}+00 \quad 0.000 \mathrm{E}+00 \quad 0.000 \mathrm{E}+00\end{array}$ 
TABLE G.2. Time of Peak Concentrations in Well Using $10 \mathrm{~cm} / \mathrm{yr}$ Recharge for Radionuclide Constituents

\begin{tabular}{|c|c|c|c|c|c|c|}
\hline \multirow{2}{*}{$\begin{array}{l}\text { Constituent } \\
\text { Name }\end{array}$} & \multicolumn{6}{|c|}{ Time of Maximum Concentration (years) } \\
\hline & Farm A & Farm B & Farm $C$ & Farm $S$ & Farm $T$ & Farm U \\
\hline Ac225 & 0 & 0 & 0 & 0 & $\begin{array}{c}\cdots \\
0\end{array}$ & 0 \\
\hline Ac227 & 0 & 0 & 0 & 0 & 0 & 0 \\
\hline *Th227 & 0 & 0 & 0 & 0 & 0 & 0 \\
\hline$\star^{\star} \operatorname{Ra} 223$ & 0 & 0 & 0 & 0 & 0 & 0 \\
\hline Am241 & 0 & 0 & 0 & 0 & 0 & 0 \\
\hline \#Np237 & 0 & 0 & 0 & 0 & 0 & 0 \\
\hline ^Pa233 & 0 & 0 & 0 & 0 & 0 & 0 \\
\hline •U233 & 0 & 0 & 0 & 0 & 0 & 0 \\
\hline Am242 & 0 & 0 & 0 & 0 & 0 & 0 \\
\hline Am242m & 0 & 0 & 0 & 0 & 0 & 0 \\
\hline${ }^{\star} \mathrm{Cm} 242$ & 0 & 0 & 0 & 0 & 0 & 0 \\
\hline „Pu238 & 0 & 0 & 0 & 0 & 0 & 0 \\
\hline \#U234 & 0 & 0 & 0 & 0 & 0 & 0 \\
\hline •Th230 & 0 & 0 & 0 & 0 & 0 & 0 \\
\hline $\mathrm{C} 14$ & 1780 & 720 & 950 & 640 & 600 & 630 \\
\hline Cs 135 & 0 & 0 & 0 & 0 & 0 & 0 \\
\hline Cs137 & 0 & 0 & 0 & 0 & 0 & 0 \\
\hline I1 29 & 1780 & 720 & 960 & 610 & 570 & 630 \\
\hline Nb93m & 9820 & 9760 & 9880 & 7610 & 8970 & 9870 \\
\hline Ni63 & 7530 & 7410 & 6700 & 416 & 4140 & 4710 \\
\hline Np237 & 9890 & 0 & 0 & 9840 & 9760 & 9830 \\
\hline ^Pa233 & 0 & 0 & 0 & 0 & 0 & 0 \\
\hline *U233 & 1780 & 720 & 960 & 910 & 570 & 630 \\
\hline Pa231 & 0 & 0 & 0 & 9370 & 9850 & 630 \\
\hline${ }^{*} A C 227$ & 0 & 0 & 0 & 9370 & 9850 & 630 \\
\hline ^Th227 & 0 & 0 & 0 & 9370 & 9850 & 630 \\
\hline $\operatorname{Ra} 223$ & 0 & 0 & 0 & 9370 & 9850 & 630 \\
\hline $\mathrm{Pa} 233$ & 0 & 0 & 0 & 0 & 0 & 0 \\
\hline *Pb210 & 0 & 0 & 0 & 0 & 0 & 0 \\
\hline Po210 & 0 & 0 & 0 & 0 & 0 & 0 \\
\hline Po210 & 0 & 0 & 0 & 0 & 0 & 0 \\
\hline Pu238 & 0 & 0 & 0 & 0 & 0 & 0 \\
\hline •U234 & 1780 & 720 & 960 & 910 & 570 & 630 \\
\hline${ }^{*}$ Th230 & 0 & 0 & 0 & 0 & 0 & 0 \\
\hline Pu239 & 0 & 0 & 0 & 0 & 0 & 0 \\
\hline *U235 & 1780 & 720 & 960 & 910 & 570 & 630 \\
\hline Pu240 & & 0 & 0 & 0 & 0 & 0 \\
\hline *U236 & 1780 & 720 & 960 & 910 & 570 & 630 \\
\hline Pu241 & 0 & 0 & 0 & 0 & 0 & \\
\hline *Am241 & 0 & 0 & 0 & 0 & 0 & 0 \\
\hline *Np237 & 0 & 0 & 0 & 0 & 0 & 0 \\
\hline *Pa233 & 0 & 0 & 0 & 0 & 0 & 0 \\
\hline *U233 & 1780 & 720 & 960 & 910 & 570 & 630 \\
\hline
\end{tabular}

NOTE: " 0 " for the time of peak concentrations indicates no peak occurred. 
IABLE G.2. (contd)

Time of Maximum Concentration (years)

\begin{tabular}{|c|c|c|c|c|c|c|}
\hline $\begin{array}{l}\text { Name } \\
\text { Natil }\end{array}$ & Farm A & Farm B & Farm C & Farm $S$ & Farn $T$ & Farm U \\
\hline Ra223 & 0 & - & 0 & $\cdots$ & 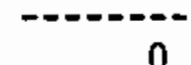 & 0 \\
\hline $\operatorname{Ra} 225$ & 0 & 0 & $\begin{array}{l}0 \\
0\end{array}$ & $\begin{array}{l}0 \\
0\end{array}$ & $\begin{array}{l}0 \\
0\end{array}$ & 0 \\
\hline $\mathrm{Ra} 226$ & 0 & 0 & 0 & 0 & 0 & 0 \\
\hline $\mathrm{Pb} 210$ & 0 & 0 & 0 & 0 & 0 & 0 \\
\hline Po210 & 0 & 0 & 0 & 0 & 0 & 0 \\
\hline Ru106 & 0 & 0 & 0 & 0 & 0 & 0 \\
\hline $\mathrm{Se} 79$ & 0 & 0 & 0 & 0 & 0 & 0 \\
\hline Sm151 & 0 & 0 & 0 & 0 & 0 & 0 \\
\hline Sn126 & 0 & 0 & 0 & 0 & 0 & 0 \\
\hline Sr90 & 0 & 0 & 0 & 0 & 0 & 0 \\
\hline$\star Y 90$ & 0 & 0 & 0 & 0 & 0 & 0 \\
\hline Tc99 & 1710 & 700 & 960 & 750 & 650 & 630 \\
\hline Th229 & 0 & 0 & 0 & 0 & 0 & 0 \\
\hline $\operatorname{Ra} 225$ & 0 & 0 & 0 & 0 & 0 & 0 \\
\hline Ac2225 & 0 & 0 & 0 & 0 & 0 & 0 \\
\hline Th230 & 0 & 0 & 0 & 0 & 0 & 0 \\
\hline Th234 & 0 & 0 & 0 & 0 & 0 & 0 \\
\hline U233 & 1640 & 750 & 960 & 750 & 570 & 630 \\
\hline *Th229 & 1640 & 910 & 960 & 750 & 880 & 680 \\
\hline${ }^{*} \mathrm{Ra} 225$ & 1640 & 910 & 960 & 750 & 880 & 680 \\
\hline${ }^{\star} \mathrm{Ac} 225$ & 1640 & 910 & 960 & 750 & 880 & 680 \\
\hline $\mathrm{Cm} 242$ & 0 & 0 & 0 & 0 & 0 & 0 \\
\hline *Pu238 & 0 & 0 & 0 & 0 & 0 & 0 \\
\hline *U234 & 1780 & 720 & 960 & 910 & 570 & 630 \\
\hline *Th230 & 0 & 0 & 0 & 0 & 0 & 0 \\
\hline $\mathrm{Cm} 244$ & 0 & 0 & 0 & 0 & 0 & 0 \\
\hline *Pu240 & & 0 & 0 & 0 & 0 & 0 \\
\hline *U236 & 1780 & 720 & 960 & 910 & 570 & 630 \\
\hline $\mathrm{Cm} 245$ & 0 & 0 & 0 & 0 & 0 & 0 \\
\hline \#Pu241 & 0 & 0 & 0 & 0 & 0 & 0 \\
\hline *Am241 & 0 & 0 & 0 & 0 & 0 & 0 \\
\hline *Np237 & 0 & 0 & 0 & 0 & 0 & 0 \\
\hline *Pa233 & 0 & 0 & 0 & 0 & 0 & 0 \\
\hline *U233 & 0 & 0 & 0 & 0 & 0 & 0 \\
\hline U234 & 1640 & 750 & 890 & 750 & 570 & 630 \\
\hline *Th230 & 1640 & 910 & 960 & 750 & 840 & 680 \\
\hline $\begin{array}{l}\text { U235 } \\
\star 0232\end{array}$ & 1780 & 750 & 960 & 750 & 610 & 630 \\
\hline $\begin{array}{l}{ }^{*} \mathrm{~Pa} 231 \\
{ }^{*} \mathrm{Ac} 227\end{array}$ & 1780 & 910 & 960 & 750 & 840 & 680 \\
\hline *Th227 & $\begin{array}{l}1780 \\
1780\end{array}$ & $\begin{array}{l}910 \\
910\end{array}$ & 960 & 750 & $\begin{array}{l}840 \\
840\end{array}$ & 680 \\
\hline *Ra223 & 1780 & 910 & 960 & 750 & 840 & 680 \\
\hline U238 & 1780 & 750 & 890 & 750 & 610 & 630 \\
\hline *Th234 & 1780 & 750 & 890 & 750 & 610 & 630 \\
\hline Y90 & 0 & 0 & 0 & 0 & 0 & 0 \\
\hline
\end{tabular}

NOTE: " 0 " for the time of peak concentrations indicates no peak occurred. 
IABLE G.3. Peak Concentrations in Well Using $10 \mathrm{~cm} / \mathrm{yr}$

Recharge for Chemicals with TRAC Inventory Data

Maximum Constituent Concentration $(g / m l)$

\begin{tabular}{|c|c|c|c|c|c|c|}
\hline ame & Farm A & Farm B & Farm C & Farm S & Farm $T$ & Farm U \\
\hline $\begin{array}{l}\mathrm{Ag} \\
\mathrm{Al} \\
\mathrm{Ba} \\
\mathrm{Cl} \\
\mathrm{Cr} \\
\mathrm{EDTA} \\
\mathrm{F} \\
\mathrm{Fe} \\
\mathrm{Fe}(\mathrm{Cn})_{6} \\
\mathrm{Mn} \\
\mathrm{MO} 2 \\
\mathrm{NO}_{3} \\
\mathrm{Na} \\
\mathrm{Ni} \\
\mathrm{Pb} \\
\mathrm{SO}_{4} \\
\mathrm{ZrO}\end{array}$ & $\begin{array}{l}2.30 \mathrm{E}-14 \\
0.00 \mathrm{E}+00 \\
0.00 \mathrm{E}+00 \\
4.55 \mathrm{E}-14 \\
3.88 \mathrm{E}-08 \\
2.33 \mathrm{E}-05 \\
1.31 \mathrm{E}-05 \\
5.18 \mathrm{E}-13 \\
1.30 \mathrm{E}-07 \\
0.00 \mathrm{E}+00 \\
1.04 \mathrm{E}-03 \\
1.09 \mathrm{E}-02 \\
7.60 \mathrm{E}-02 \\
4.34 \mathrm{E}-11 \\
0.00 \mathrm{E}+00 \\
5.88 \mathrm{E}-03 \\
0.00 \mathrm{E}+00\end{array}$ & $\begin{array}{l}1.76 \mathrm{E}-06 \\
0.00 \mathrm{E}+00 \\
0.00 \mathrm{E}+00 \\
6.60 \mathrm{E}-13 \\
6.96 \mathrm{E}-08 \\
1.19 \mathrm{E}-05 \\
2.14 \mathrm{E}-03 \\
3.99 \mathrm{E}-17 \\
1.10 \mathrm{E}-06 \\
0.00 \mathrm{E}+00 \\
1.89 \mathrm{E}-02 \\
1.31 \mathrm{E}-02 \\
9.19 \mathrm{E}-02 \\
6.11 \mathrm{E}-12 \\
0.00 \mathrm{E}+00 \\
3.15 \mathrm{E}-03 \\
0.00 \mathrm{E}+00\end{array}$ & $\begin{array}{l}5.81 \mathrm{E}-14 \\
0.00 \mathrm{E}+00 \\
0.00 \mathrm{E}+00 \\
2.53 \mathrm{E}-15 \\
1.31 \mathrm{E}-08 \\
2.42 \mathrm{E}-06 \\
1.48 \mathrm{E}-03 \\
2.22 \mathrm{E}-13 \\
1.10 \mathrm{E}-06 \\
0.00 \mathrm{E}+00 \\
3.30 \mathrm{E}-05 \\
1.31 \mathrm{E}-02 \\
1.67 \mathrm{E}-02 \\
5.94 \mathrm{E}-11 \\
0.00 \mathrm{E}+00 \\
6.07 \mathrm{E}-04 \\
0.00 \mathrm{E}+00\end{array}$ & $\begin{array}{l}1.72 \mathrm{E}-12 \\
0.00 \mathrm{E}+00 \\
0.00 \mathrm{E}+00 \\
2.24 \mathrm{E}-12 \\
1.42 \mathrm{E}-03 \\
2.81 \mathrm{E}-05 \\
1.69 \mathrm{E}-03 \\
1.99 \mathrm{E}-04 \\
1.10 \mathrm{E}-06 \\
0.00 \mathrm{E}+00 \\
2.97 \mathrm{E}-02 \\
1.31 \mathrm{E}-02 \\
9.19 \mathrm{E}-02 \\
3.99 \mathrm{E}-06 \\
0.00 \mathrm{E}+00\end{array}$ & $\begin{array}{l}7.43 \mathrm{E}-13 \\
0.00 \mathrm{E}+00 \\
0.00 \mathrm{E}+00 \\
6.81 \mathrm{E}-12 \\
3.33 \mathrm{E}-05 \\
2.81 \mathrm{E}-05 \\
3.55 \mathrm{E}-03 \\
1.88 \mathrm{E}-05 \\
1.10 \mathrm{E}-06 \\
0.00 \mathrm{E}+00 \\
3.25 \mathrm{E}-02 \\
1.31 \mathrm{E}-02 \\
9.19 \mathrm{E}-02 \\
2.67 \mathrm{E}-06 \\
0.00 \mathrm{E}+00 \\
8.46 \mathrm{E}-03 \\
0.00 \mathrm{E}+00\end{array}$ & $\begin{array}{l}4.92 \mathrm{E}-14 \\
0.00 \mathrm{E}+00 \\
0.00 \mathrm{E}+00 \\
6.81 \mathrm{E}-14 \\
4.78 \mathrm{E}-05 \\
2.81 \mathrm{E}-05 \\
2.59 \mathrm{E}-04 \\
3.94 \mathrm{E}-07 \\
1.10 \mathrm{E}-11 \\
0.00 \mathrm{E}+00 \\
2.55 \mathrm{E}-03 \\
1.31 \mathrm{E}-02 \\
2.90 \mathrm{E}-03 \\
2.26 \mathrm{E}-07 \\
7.42 \mathrm{E}-12 \\
1.07 \mathrm{E}-06 \\
0.00 \mathrm{E}+00\end{array}$ \\
\hline
\end{tabular}

TABLE G.4. Time of Peak Concentrations in Well Using $10 \mathrm{~cm} / \mathrm{yr}$ Recharge for Chemicals with TRAC Inventory Data

Time of Maximum Concentration (years)

\begin{tabular}{lrrrrrr} 
Constituent & $r$ & & & & \\
Name & Farm A & Farm B & Farm C & Farm S & Farm T & Farm U \\
\hdashline $\mathrm{Ag}$ & 6680 & 5250 & 7040 & 2800 & 3330 & 4310 \\
$\mathrm{Al}$ & 0 & 0 & 0 & 0 & 0 & 0 \\
$\mathrm{Ba}$ & 0 & 0 & 0 & 0 & 0 & 0 \\
$\mathrm{Cl}$ & 840 & 720 & 880 & 570 & 530 & 630 \\
$\mathrm{Cr}$ & 9820 & 9750 & 9830 & 5800 & 7540 & 9820 \\
$\mathrm{EDTA}$ & 2420 & 720 & 810 & 570 & 530 & 580 \\
$\mathrm{~F}$ & 840 & 720 & 880 & 570 & 530 & 580 \\
$\mathrm{Fe}$ & 9890 & 9910 & 9770 & 8440 & 9650 & 9950 \\
$\mathrm{Fe}(\mathrm{Cn})_{6}$ & 840 & 850 & 1180 & 570 & 530 & 630 \\
$\mathrm{Mn}$ & 0 & 0 & 0 & 0 & 0 & 0 \\
$\mathrm{NO} 2$ & 840 & 720 & 880 & 570 & 530 & 630 \\
$\mathrm{NO}$ & 2290 & 670 & 1090 & 430 & 530 & 580 \\
$\mathrm{Na}$ & 2420 & 720 & 880 & 570 & 530 & 9820 \\
$\mathrm{Ni}$ & 9750 & 9730 & 9820 & 7110 & 8940 & 530 \\
$\mathrm{~Pb}$ & 0 & 0 & 0 & 0 & 0 & 0 \\
$\mathrm{SO}$ & 1040 & 720 & 810 & 0 & 530 & 9950 \\
$\mathrm{Zr}$ & 0 & 0 & 0 & 0 & 0 & 0
\end{tabular}


IABLE G.5. Peak Concentrations in Well Using $10 \mathrm{~cm} / \mathrm{yr}$ Recharge for Additional Chemicals of Concern Using an Assumed 1\% Inventory

\begin{tabular}{|c|c|c|c|c|c|c|}
\hline \multirow{2}{*}{$\begin{array}{l}\text { Const ituent } \\
\text { Name }\end{array}$} & \multicolumn{6}{|c|}{ Maximum Constituent Concentration $(\mathrm{g} / \mathrm{m} \mathrm{l})$} \\
\hline & & Farm & Farm C & Farm $\mathrm{S}$ & Farm $T$ & Farm U \\
\hline $\begin{array}{l}\mathrm{Be} \\
\mathrm{Cd} \\
\mathrm{Cu} \\
\mathrm{Hg} \\
\mathrm{Sb} \\
\mathrm{Se}\end{array}$ & $\begin{array}{l}--. \\
1.0 \\
1.5 \\
2.9 \\
0.0 \\
2.6 \\
1.2 \\
0.0 \\
1.2\end{array}$ & $\begin{array}{l}3.45 \mathrm{E}-04 \\
2.28 \mathrm{E}-06 \\
0.00 \mathrm{E}+00 \\
0.00 \mathrm{E}+00 \\
3.20 \mathrm{E}-04 \\
7.77 \mathrm{E}-03 \\
0.00 \mathrm{E}+00 \\
7.77 \mathrm{E}-03\end{array}$ & $\begin{array}{l}9.86 \mathrm{E}-05 \\
2.23 \mathrm{E}-06 \\
0.00 \mathrm{E}+00 \\
0.00 \mathrm{E}+00 \\
3.20 \mathrm{E}-04 \\
1.33 \mathrm{E}-03 \\
0.00 \mathrm{E}+00 \\
1.33 \mathrm{E}-03\end{array}$ & $\begin{array}{l}3.45 \mathrm{E}- \\
3.48 \mathrm{E}- \\
1.42 \mathrm{E}- \\
3.08 \mathrm{E}- \\
3.20 \mathrm{E}- \\
8.46 \mathrm{E}- \\
0.00 \mathrm{E}+ \\
8.46 \mathrm{E}-\end{array}$ & $\begin{array}{l}3.45 \\
2.52 \\
2.66 \\
3.19 \\
3.20 \\
8.46 \\
0.00 \\
8.46\end{array}$ & $\begin{array}{l}3.45 \mathrm{E}-04 \\
2.13 \mathrm{E}-06 \\
9.17 \mathrm{E}-20 \\
2.07 \mathrm{E}-32 \\
3.20 \mathrm{E}-04 \\
8.36 \mathrm{E}-03 \\
0.00 \mathrm{E}+00 \\
8.36 \mathrm{E}-03\end{array}$ \\
\hline
\end{tabular}

TABLE G.6. Time of Peak Concentrations in Well Using $10 \mathrm{~cm} / \mathrm{yr}$ Recharge for Additional Chemicals of Concern

\begin{tabular}{|c|c|c|c|c|c|c|}
\hline \multirow{2}{*}{$\begin{array}{l}\text { Const ituent } \\
\text { Name }\end{array}$} & \multicolumn{6}{|c|}{ Maximum Constituent Concentration $(\mathrm{g} / \mathrm{ml})$} \\
\hline & Farm A & Farm B & Farm C & Farm $S$ & Farm $T$ & Farm U \\
\hline $\begin{array}{l}\mathrm{AS} \\
\mathrm{Be} \\
\mathrm{Cd} \\
\mathrm{Cu} \\
\mathrm{Hg} \\
\mathrm{Sb} \\
\mathrm{Se} \\
\mathrm{V}\end{array}$ & $\begin{array}{r}9810 \\
840 \\
9850 \\
0 \\
1850 \\
840 \\
0 \\
840\end{array}$ & $\begin{array}{r}7670 \\
670 \\
0 \\
0 \\
680 \\
720 \\
0 \\
720\end{array}$ & $\begin{array}{r}9720 \\
1180 \\
0 \\
0 \\
1090 \\
880 \\
0 \\
880\end{array}$ & $\begin{array}{r}3930 \\
570 \\
9850 \\
9930 \\
440 \\
570 \\
0 \\
570\end{array}$ & $\begin{array}{r}4730 \\
540 \\
9770 \\
9910 \\
470 \\
530 \\
0 \\
530\end{array}$ & $\begin{array}{r}5820 \\
550 \\
9830 \\
9840 \\
580 \\
630 \\
0 \\
630\end{array}$ \\
\hline
\end{tabular}

NOTE: " 0 " for the time of peak concentrations indicates no peak occurred. 


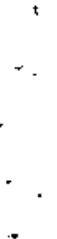




\section{APPENDIX H}

TABLES OF HEALTH RANKING INDICES 


\section{APPENDIX H}

\section{TABLES OF HEALTH RANKING INDICES}

TABLE H.1. Health Ranking Indices for Radionuclides in Tank

Farm A with TRAC Inventories and Varying Recharge Rates

\begin{tabular}{|c|c|c|c|c|}
\hline Constituent & $0.5 \mathrm{~cm} / \mathrm{rr}$ & $1.0 \mathrm{co} / \mathrm{Hr}$ & $16.6 \mathrm{~cm} / \mathrm{yr}$ & 10.0 $\mathrm{cm} / \mathrm{yr}(\mathrm{a})$ \\
\hline A-241 (b) & $1.8 \times 10^{-7}$ & $2.1 \times 10^{-6}$ & $8.6 \times 10-5$ & $8.6 \times 10^{-5}$ \\
\hline$A=242 \square(b)$ & $8.6 \times 10^{-5}$ & $8.8 \times 10^{-4}$ & $3.8 \times 10^{-3}$ & $6.8 \times 10^{-3}$ \\
\hline C14 & $4.7 \times 10^{-4}$ & $8.3 \times 10-3$ & $5.7 \times 18-2$ & $6.7 \times 10^{-2}$ \\
\hline Can242 (b) & $1.3 \times 10^{-6}$ & $1.5 \times 10-5$ & $5.0 \times 10-5$ & $5.9 \times 16-5$ \\
\hline $\cos 24$ (b) & $8.8 \times 10-10$ & $7.9 \times 10-8$ & $3.0 \times 10-6$ & $3.0 \times 10-8$ \\
\hline $\mathrm{C} \times 245$ & - & - & - & $2.0 \times 10^{-15}$ \\
\hline 1129 & $1.5 \times 18-4$ & $1.7 \times 10^{-3}$ & $6.8 \times 10^{-3}$ & $8.6 \times 10^{-3}$ \\
\hline Nb83a & - & - & $4.0 \times 16-8$ & $1.2 \times 10-2$ \\
\hline $\mathrm{Ni} \mathbf{\mathrm { N3 }}$ & - & - & - & $0.7 \times 16-12$ \\
\hline Np237 (b) & $2.1 \times 10^{-7}$ & $2.4 \times 16-6$ & $2.2 \times 18-5$ & $1.4 \times 10^{-1}$ \\
\hline $\mathrm{Pa} 231$ & - & - & - & $3.8 \times 10^{-5}$ \\
\hline$P=233$ & - & - & - & $1.0 \times 18^{-6}$ \\
\hline PL238 (b) & $1.2 \times 10-5$ & $1.4 \times 10^{-4}$ & $5.4 \times 16^{-4}$ & $6.4 \times 10-4$ \\
\hline Pu239 (b) & $8.5 \times 10^{-6}$ & $8.8 \times 10^{-5}$ & $9.4 \times 10^{-4}$ & $0.0 \times 10^{-4}$ \\
\hline Pu248 (b) & $3.9 \times 10^{-5}$ & $4.5 \times 10^{-4}$ & $1.7 \times 10^{-3}$ & $1.7 \times 10-3$ \\
\hline Pu241 (b) & $4.5 \times 10^{-8}$ & $5.3 \times 10^{-7}$ & $4.8 \times 18-8$ & $4.8 \times 18-6$ \\
\hline Se78 & - & - & - & $B .4 \times 10^{-7}$ \\
\hline Te9s & $2.0 \times 18-3$ & $2.4 \times 10^{-2}$ & $9.1 \times 16-2$ & $9.1 \times 10-2$ \\
\hline U233 & $1.8 \times 10-7$ & $2.1 \times 10^{-8}$ & $1.9 \times 10^{-5}$ & $8.3 \times 10^{-6}$ \\
\hline U234 & $3.1 \times 10-6$ & $3.6 \times 10^{-5}$ & $1.4 \times 10^{-4}$ & $1.4 \times 10^{-4}$ \\
\hline U235 & $1.1 \times 10^{-4}$ & $1.3 \times 10^{-3}$ & $5.1 \times 18-3$ & $5.0 \times 10-3$ \\
\hline U238 & $2.4 \times 10^{-3}$ & $2.7 \times 10^{-2}$ & $1.0 \times 10-1$ & $1.6 \times 10-1$ \\
\hline
\end{tabular}

(a) Sensitivity case with onhanced transport rate.

(b) Risk is from decay products. 
TABLE H.2. Health Ranking Indices for Chemicals in Tank Farm A with IRAC Inventories and Varying Recharge Rates

Tank Farn $A$

\begin{tabular}{|c|c|c|c|c|}
\hline Const ituent & E.5 ca/yr & $1.0 \mathrm{co} / \mathrm{yr}$ & $10.0 \mathrm{cu} / \mathrm{xr}$ & $16.0 \mathrm{~cm} / \mathrm{yr}(\mathrm{a}$ \\
\hline$A_{\theta}$ & - & - & $1.2 \times 10-6$ & $3.4 \times 10^{-6}$ \\
\hline $\mathrm{Cl}$ & $2.8 \times 18-10$ & $2.0 \times 10^{-9}$ & $3.4 \times 10^{-8}$ & $3.4 \times 16-8$ \\
\hline $\mathrm{Cr}$ & - & - & $3.2 \times 10-1$ & $1.2 \times 162$ \\
\hline EDTA & $5.1 \times 101$ & $2.2 \times 10^{3}$ & $3.7 \times 104$ & $3.7 \times 104$ \\
\hline $\mathbf{F}$ & $1.1 \times 10^{-1}$ & $8.8 \times 10-1$ & $1.4 \times 101$ & $1.4 \times 181$ \\
\hline Fo & - & - & $1.6 \times 10^{-8}$ & $5.2 \times 100$ \\
\hline $\mathrm{Cn}$ & $1.1 \times 10^{-1}$ & $1.1 \times 100$ & $1.7 \times 161$ & $1.7 \times 101$ \\
\hline $\mathrm{NO}_{2}$ & $1.8 \times 101$ & $7.6 \times 102$ & $1.1 \times 1.4$ & $1.1 \times 104$ \\
\hline $\mathrm{NO}_{3}$ & $6.4 \times 10^{-1}$ & $2.7 \times 101$ & $3.9 \times 10^{2}$ & $3.8 \times 182$ \\
\hline Na & $7.3 \times 10^{-2}$ & $3.1 \times 19$ & $5.4 \times 10^{0}$ & $4.6 \times 101$ \\
\hline $\mathrm{Hi}$ & - & - & $1.0 \times 10^{-4}$ & $1.0 \times 101$ \\
\hline $\mathrm{SO}_{4}$ & $5.6 \times 10^{-3}$ & $2.1 \times 10^{-1}$ & $3.0 \times 190$ & $3.0 \times 100$ \\
\hline $2 r 0$ & - & - & - & $8.6 \times 10^{-3}$ \\
\hline
\end{tabular}

(a) Sensitivity case vith enhanced transport rake.

IABLE H.3. Health Ranking Indices for Chemicals in Tank Farm A without TRAC Inventories and Varying Recharge Rates (assumed $1 \%$ by weight of total)

\begin{tabular}{|c|c|c|c|c|}
\hline Constituent & $0.5 \mathrm{co} / \mathrm{yr}$ & $1.0 \mathrm{~cm} / \mathrm{yr}$ & $10.6 \mathrm{co} / \mathrm{yr}$ & $16.0 \mathrm{~cm} / \mathrm{yr} \quad 10$ \\
\hline As & - & - & $7.1 \times 10^{0}$ & $1.8 \times 101$ \\
\hline$\infty$ & $8.8 \times 18-1$ & $3.7 \times 101$ & $6.8 \times 10^{2}$ & $8.8 \times 18^{2}$ \\
\hline $\mathrm{Cd}$ & - & - & - & $2.9 \times 104$ \\
\hline $\mathrm{cu}$ & - & - & - & $2.5 \times 101$ \\
\hline $\mathrm{Hg}$ & $5.1 \times 181$ & $2.1 \times 10^{3}$ & $3.1 \times 104$ & $3.1 \times 164$ \\
\hline Sb & $7.8 \times 162$ & $0.3 \times 10^{3}$ & $1.3 \times 105$ & $1.3 \times 105$ \\
\hline Se & - & - & - & $6.0 \times 10^{0}$ \\
\hline$Y$ & $1.4 \times 10^{1}$ & $1.5 \times 162$ & $2.3 \times 10^{3}$ & $2.4 \times 10^{3}$ \\
\hline
\end{tabular}

(a) Sensitivity case vith enhanced transport rate. 
TABLE H.4. Health Ranking Indices for Radionuclides in Tank Farms with TRAC Inventories and $10 \mathrm{~cm} / \mathrm{yr}$ Recharge Rate

Tank Fan

\begin{tabular}{|c|c|c|c|c|c|c|}
\hline Constituent & $A$ & $\theta$ & C & $s$ & I & $\underline{U}$ \\
\hline C14 & $5.7 \times 10-2$ & $1.3 \times 10^{0}$ & $1.9 \times 18-1$ & $1.3 \times 10^{4}$ & $2.1 \times 10^{8}$ & $8.0 \times 10-2$ \\
\hline I129 & $6.6 \times 10^{-3}$ & $1.1 \times 10^{8}$ & $1.2 \times 10-1$ & $1.2 \times 10^{9}$ & $1.5 \times 10^{8}$ & $1.1 \times 10-1$ \\
\hline Nb93. & $4.8 \times 10-8$ & $5.1 \times 10^{-7}$ & $3.7 \times 10^{-8}$ & $2.1 \times 10-2$ & $1.1 \times 10-3$ & $1.9 \times 10-4$ \\
\hline Te8g & $9.1 \times 10-2$ & $1.4 \times 101$ & $1.2 \times 10^{0}$ & $1.0 \times 101$ & $2.3 \times 10^{1}$ & $1.8 \times 10^{9}$ \\
\hline U233 & $1.8 \times 10^{-6}$ & $9.1 \times 10-5$ & $1.0 \times 10^{-5}$ & $8.0 \times 10-5$ & $1.7 \times 10^{-4}$ & $2.8 \times 10^{-5}$ \\
\hline U234 & $1.4 \times 10-4$ & $8.6 \times 10^{-4}$ & $7.0 \times 10-4$ & $2.3 \times 10-3$ & $6.3 \times 10-3$ & $1.2 \times 10-3$ \\
\hline U235 & $5.1 \times 10-3$ & $1.7 \times 10-1$ & $6.4 \times 10^{-2}$ & $9.8 \times 10-2$ & $1.1 \times 10^{0}$ & $1.8 \times 10-1$ \\
\hline v238 & $1.0 \times 10^{-1}$ & $3.8 \times 10^{6}$ & $1.6 \times 10^{0}$ & $1.9 \times 10^{0}$ & $2.7 \times 161$ & $6.1 \times 10^{0}$ \\
\hline
\end{tabular}

TABLE H.5. Health Ranking Indices for Parent Radionuclides Scoring Because of Decay-Product in Tank Farm with TRAC Inventories and $10 \mathrm{~cm} / \mathrm{yr}$ Recharge Rate

Tank Fart

Parent (Decay)

_... Nane

An241 (U233)

A.242! (U234)

C.242 (U234)

Ca244 (U236)

Np237 (U233)

Pu238 (U234)

Pu239 (U235)

Pu240 (U236)

Pu241 (U233)

\begin{tabular}{|c|c|}
\hline$A$ & 且 \\
\hline $6.6 \times 10^{-5}$ & $1.2 \times 10^{-4}$ \\
\hline $3.8 \times 10-3$ & $8.2 \times 10-2$ \\
\hline $5.9 \times 10-5$ & $1.4 \times 10-4$ \\
\hline $3.0 \times 10-8$ & $1.7 \times 10-7$ \\
\hline $2.2 \times 10-5$ & $2.0 \times 10-3$ \\
\hline $5.4 \times 10^{-4}$ & $4.2 \times 10-4$ \\
\hline $9.0 \times 10^{-4}$ & $6.3 \times 10^{-4}$ \\
\hline $1.7 \times 18^{-3}$ & $1.0 \times 10^{-3}$ \\
\hline $4.8 \times 10-6$ & $4.6 \times 18-6$ \\
\hline
\end{tabular}

(2)

\begin{tabular}{l}
5 \\
\hline $1.3 \times 10^{-4}$ \\
$0.3 \times 10^{-3}$ \\
$1.2 \times 10^{-4}$ \\
$3.6 \times 10^{-8}$ \\
$5.4 \times 10^{-4}$ \\
$6.8 \times 10^{-4}$ \\
$7.0 \times 10^{-4}$ \\
$1.1 \times 10^{-3}$ \\
$2.6 \times 10^{-6}$
\end{tabular}

4

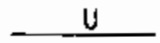

$3.0 \times 10-5$

$1.3 \times 10-3$

$2.8 \times 10^{-4}$

$1.1 \times 10-8$

$4.4 \times 10-4$

$4.6 \times 10-4$

$4.9 \times 10-4$

$5.8 \times 10^{-4}$

$1.8 \times 10^{-6}$

$4.2 \times 10-6$

$1.7 \times 10-4$

$3.0 \times 10-6$

$1.3 \times 10-8$

$3.8 \times 10-5$

$9.7 \times 10^{-5}$

$3.9 \times 10-5$

$5.5 \times 10-5$

$1.2 \times 10^{-7}$ 
IABLE H.6. Health Ranking Indices for Chemicals in Tank

Farm with TRAC Inventories $10 \mathrm{~cm} / \mathrm{yr}$ Recharge Rate

Tank Farn

\begin{tabular}{|c|c|c|c|c|c|c|}
\hline Constituent & $A$ & B & $c$ & $s$ & $T$ & $\underline{U}$ \\
\hline $\mathrm{Ag}$ & $1.2 \times 10-6$ & $6.8 \times 16-5$ & $3.0 \times 10-6$ & $8.7 \times 10^{-5}$ & $3.8 \times 10-5$ & $2.5 \times 10-6$ \\
\hline $\mathrm{Cl}$ & $3.4 \times 10^{-8}$ & $5.0 \times 10-7$ & $1.0 \times 10-9$ & $1.7 \times 10^{-6}$ & $5.1 \times 10-6$ & $5.1 \times 10-8$ \\
\hline $\mathrm{Cr}$ & $3.2 \times 10-1$ & $3.8 \times 10^{6}$ & $1.1 \times 16-1$ & $1.2 \times 10^{4}$ & $2.9 \times 10^{2}$ & $4.1 \times 102$ \\
\hline ETA & $3.7 \times 104$ & $1.6 \times 104$ & $3.3 \times 10^{3}$ & $3.8 \times 104$ & $3.8 \times 104$ & $3.8 \times 164$ \\
\hline$F$ & $1.4 \times 101$ & $2.3 \times 163$ & $1.8 \times 10^{3}$ & $1.0 \times 10^{3}$ & $3.8 \times 10^{3}$ & $2.8 \times 102$ \\
\hline $\mathrm{Fe}$ & $1.6 \times 10^{-8}$ & $4.4 \times 10-7$ & $6.6 \times 10^{-9}$ & $6.3 \times 10^{0}$ & $5.8 \times 10-1$ & $1.4 \times 10^{-1}$ \\
\hline $\mathrm{Cn}$ & $1.7 \times 101$ & $1.5 \times 10^{2}$ & $1.5 \times 10^{2}$ & $1.5 \times 10^{2}$ & $1.5 \times 182$ & $1.4 \times 10^{-3}$ \\
\hline $\mathrm{NO}_{2}$ & $1.1 \times 10^{4}$ & $1.4 \times 105$ & $5.0 \times 10^{2}$ & $3.1 \times 105$ & $3.5 \times 165$ & $1.1 \times 104$ \\
\hline $\mathrm{NO}_{3}$ & $3.9 \times 102$ & $4.9 \times 102$ & $4.9 \times 102$ & $4.9 \times 102$ & $4.9 \times 102$ & $4.9 \times 102$ \\
\hline $\mathrm{Na}$ & $6.4 \times 10^{0}$ & $5.6 \times 181$ & $9.7 \times 10^{6}$ & $5.5 \times 181$ & $5.6 \times 101$ & $2.9 \times 161$ \\
\hline $\mathrm{Ni}$ & $1.0 \times 10^{-4}$ & $8.8 \times 10-3$ & $1.5 \times 10^{-4}$ & $1.0 \times 101$ & $7.0 \times 10^{0}$ & $4.4 \times 10-1$ \\
\hline 504 & $3.0 \times 10^{6}$ & $1.6 \times 10^{6}$ & $3.1 \times 10^{-1}$ & $4.3 \times 100$ & $4.3 \times 180$ & $5.2 \times 10-1$ \\
\hline
\end{tabular}

TABLE H.7. Health Ranking Indices for Chemicals in Tank Farms without TRAC Inventories (assumed $1 \%$ by weight of total)

Tank Farn

Consti
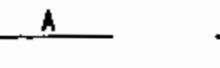

$7.1 \times 10^{0}$

\begin{abstract}
$2.4 \times 101$
\end{abstract}
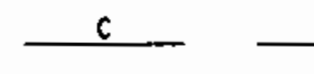

\title{
5
}

$7.0 \times 10^{0}$

$2.4 \times 101$

$6.6 \times 182$

$6.6 \times 16^{2}$

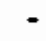

$-$

cu

$\mathrm{Hg}$

Sb

Se

$3.1 \times 104$

$1.3 \times 10^{5}$

$3.8 \times 104$

$3.0 \times 10^{4}$

$3.8 \times 10^{-}$

$1.3 \times 10^{5}$

$8.7 \times 165$

$2.3 \times 10^{3}$

B.6 $\times 10^{5}$

$1.5 \times 16^{4}$

$2.5 \times 10^{3}$

$1.6 \times 10^{4}$
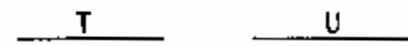

$2.4 \times 101$

$2.4 \times 161$

$6.8 \times 102$

$6.6 \times 102$

$2.1 \times 10-8$

$5.6 \times 18-4$

$5.5 \times 16-13$

$3.8 \times 10^{4}$

$3.8 \times 10^{4}$

$8.7 \times 105$

$7.9 \times 10^{5}$

$1.6 \times 104$

$1.4 \times 104$ 
PNL -7572

UC $-702,721$

\section{DISTRIBUTION}

No. of

Copies

OFFSITE

12 DOE/Office of Scientific and Technical Information

15 R. S. Andrews

National Academy of Sciences 2101 Constitution Ave., N.W. Washington, DC 20418

5 R. J. Aiken

Environmental Management

U.S. Department of Energy

Forresta] Building, EM-20

1000 Independence Avenue SW

Washington, DC 20545

P. Beam

U.S. Department of Energy

DP- 124

19901 Germantown Road

Germantown, MD 20545

J. C. Lehr

On-Site Remediation Branch

U.S. Department of Energy

Germantown, EM-442

Washington, DC 20545

T. Longo

U.S. Department of Energy

DP - 124

19901 Germantown Road

Germantown, MD 20545

J. Tseng

U.S. Department of Energy

Trevion Building 2, EM/35

12800 Middlebrook Road

Germantown, MD 20874

3 R. S. Stanley (2)

11. Lerchen (1)

State of Washington

Department of Ecology

Itai Stop PV-11

OTympia, WA 98504-87II
No. of

Copjes

ONSITE

9 DOE Richland Operations Office

M. J. Anthony

A5 -18

P. K. Clark

A5-21

R. D. Freeberg

A $5-19$

R. E. Gerton

A4 - 02

J. M. Hennig

A5-21

J. E. Newson

R4-04

D. E. Trader

A5 -90

Public Reading Room (2) Al-65

2 U.S. Environmental Protection Agency

P. T. Day

B5-01

D. R. Sherwood

B5-01

40 Westinghouse Hanford Company

M. R. Adams

H. Babad

D. E. Ball

A. L. Boldt

K. D. Boomer

J. W. Cammann

A. J. DiLiberto

J. S. Garfield

V. W. Hall

L. Jensen

J. H. Kessner

M. J. Kiem

R. J. Landon

R. E. Lerch

H. E. McGuire

R. E. Miller

R. L. Miller

A. F. Noonan

B. E. Opitz

J. G. Propson

R. E. Raymond

L. M. Sasaki

E. H. Smith

J. C. Sonnichsen

R. L. Weiss

W. I. Winters
H4 - 55

H4 -23

G6-46

H5- 49

H5- 49

H4 -14

R2-18

R3-63

L4 -88

T6- 18

T6-08

R2-14

B2 - 19

B2 -35

B2 -35

T3-02

L4-88

R2 - 12

R2-83

R2-18

RI - 80

R2-12

B2-19

H4- 14

T6-08

T5- 50

Distr. 1 
PNL -7572

UC- 702,721
D. D. Wodrich
B3 -72
R. D. Wojtasek
$\mathrm{L} 4-92$
J. C. Womack
Lo- 18
D. E. Wood
B2 -19
Central Files
L8-18
Environmental Data
Management Center (6) H4-22
Publications Svcs (3) L8-07

\section{Pacific Northwest Laboratory}

W. F. Bonner

P7 -44

J. W. Buck (5)

K6-96

P. J. Chamberlain

$\mathrm{K} 7-34$

P. G. Doctor

$K 6-96$

J. G. Droppo, Jr. (5) K6-96

R. M. Ecker

SEQUI

J. W. Falco

K6-78

J. F. Fletcher

K6-31

M. D. Freshley

$\mathrm{K} 6-77$

J. M. Hales

K6-04

P. C. Hays

$K 6-86$

G. M. Holter

$\mathrm{K} 6-25$

S. T. Hwang

K6-96

B. M. Johnson, Jr.

Kl-51

T. E. Jones

P7-27

J. F. Keller

Kl-51

G. M. McNair

K6-25

M. S. Peffers

K6-25

P. A. Scott

P7 -43

R. J. Serne

K6-81

T. L. Stewart

$\mathrm{K} 5-25$

D. L. Strenge

K3-51

K. M. Tominey

$\mathrm{K} 6-25$

R. S. Wegeng

$\mathrm{K} 6-31$

G. Whelan

$K 6-96$

J. S. Wilbur

$\mathrm{K} 6-96$

T. W. Wood (5)

$K 6-25$

Publishing Coordination Kl-11 Technical Report

Files (5)

P8-55 